Hydrologic and Geochemical Factors Affecting the Chemistry of

Small Headwater Streams in Response to Acidic Deposition on Catoctin Mountain, North-Central Maryland

By Karen C. Rice and Owen P. Bricker

U.S. GEOLOGICAL SURVEY

Water-Resources Investigations Report 95-4155

Prepared in cooperation with the

MARYLAND DEPARTMENT OF THE ENVIRONMENT and the MARYLAND DEPARTMENT OF NATURAL RESOURCES

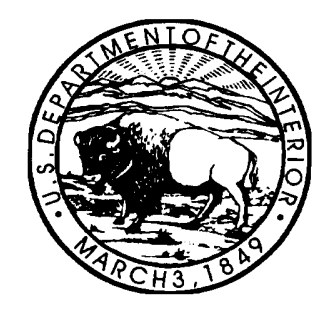




\section{U.S. DEPARTMENT OF THE INTERIOR \\ BRUCE BABBITT, Secretary U.S. GEOLOGICAL SURVEY Gordon P. Eaton, Director}

For additional information write to:

District Chief

U.S. Geological Survey

208 Carroll Building

8600 La Salle Road

Towson, MD 21286
Copies of this report can be purchased from:

U.S. Geological Survey Earth Science Information Center Open-File Reports Section Box 25286, MS 517 Denver Federal Center Denver, CO 80225 


\section{CONTENTS}

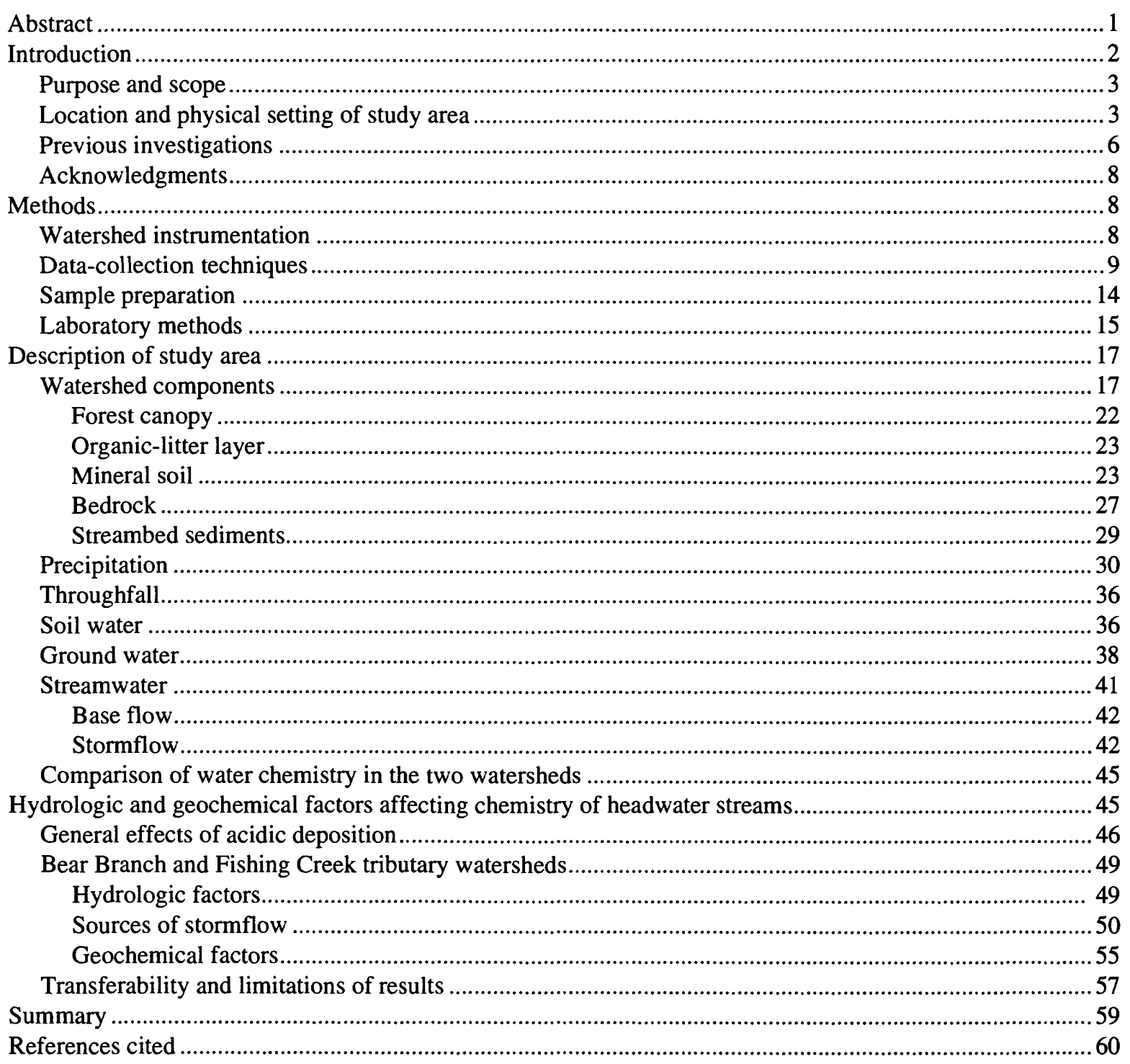




\section{FIGURES}

1-2. Maps showing location of:

1. Catoctin Mountain in Frederick County, Maryland

2. Study area on Catoctin Mountain, Maryland

3-4. Maps showing topography and instrumentation in the:

3. Bear Branch watershed, Catoctin Mountain, Maryland ............................................................ 10

4. Fishing Creek tributary watershed, Catoctin Mountain, Maryland …........................................... 12

5. Box plots showing major inorganic constituent concentrations in all water types collected from the Bear Branch and Fishing Creek tributary watersheds, Catoctin Mountain, Maryland, 1991-93.

6. Conceptual diagram showing watershed components and their effect on water chemistry

7. Graph showing grain-size fractions of soils from Fishing Creek tributary lysimeter pit 2, Catoctin Mountain, Maryland

8. Graphs showing variation in laboratory $\mathrm{pH}$ of precipitation collected from 1982-93 and sulfate and nitrate concentrations, Catoctin Mountain, Maryland

9. Graph showing the Catoctin meteoric water line and representative waters collected from the Bear Branch and Fishing Creek tributary watersheds, Catoctin Mountain, Maryland, 1991-93

10. Box plots showing major inorganic constituent concentrations in upper soil water from lysimeter pits in the Bear Branch and Fishing Creek tributary watersheds, Catoctin Mountain, Maryland, 1991-93

11. Box plots showing major inorganic constituent concentrations in lower soil water from lysimeter pits in the Bear Branch and Fishing Creek tributary watersheds, Catoctin Mountain, Maryland, 1991-93

12. Graph showing seasonal fluctuations in altitude of water table in Bear Branch well point 4 , Catoctin Mountain, Maryland, April 1991 through December 1993.

13. Hydrographs of mean daily discharge of Bear Branch, 1990-93, and Fishing Creek tributary, 1987-93, Catoctin Mountain, Maryland, and example of graphical hydrograph separation into base-flow and stormflow conditions

14. Graphs showing episodic acidification in streamwater in Bear Branch and Fishing Creek tributary watersheds, Catoctin Mountain, Maryland, June 18, 1991

15. Graphs showing isotopic variation of different types of water in Bear Branch and Fishing Creek tributary watersheds, Catoctin Mountain, Maryland, 1991-93

16. Graphs showing stream discharge and isotopic variation in streamwater in Bear Branch, June 1990 through April 1992, and Fishing Creek tributary, May 1990 through May 1992, Catoctin Mountain, Maryland

17. Reconstruction of chemical composition of streamwater in 1991 from weathering of primary and secondary minerals for Bear Branch and Fishing Creek tributary watersheds, Catoctin Mountain, Maryland 


\section{TABLES}

1. Physical characteristics of the Bear Branch and Fishing Creek tributary watersheds, Catoctin Mountain, Maryland.

2. Water-quality laboratory methods and detection limits used to analyze samples collected from Catoctin Mountain, Maryland

3. Results of organic-litter layer analyses of samples collected from Catoctin Mountain, Maryland .24

4. Results of mineral soil analyses of samples collected from Catoctin Mountain, Maryland.

5. Results of whole-rock analyses of samples collected from Catoctin Mountain, Maryland

A. Bear Branch watershed .28

B. Fishing Creek tributary watershed 28

6. Results of thin-section analyses of samples collected from Catoctin Mountain, Maryland

7. Results of streambed-sediment analyses of samples collected from Catoctin Mountain, Maryland. 30

8. Annual amount of precipitation recorded on Catoctin Mountain, Maryland, 1982-93 31

9. Volume-weighted average concentrations of chemical constituents in precipitation on Catoctin Mountain, Maryland, 1982-93

10. Precipitation (wet deposition) loadings at Catoctin Mountain, Maryland, 1982-93 .34

11. Throughfall loadings in the Bear Branch and Fishing Creek tributary watersheds, Catoctin Mountain, Maryland, 1991-93

12. Annual export of chemical constituents in streamwater of Bear Branch (1991-93) and Fishing Creek tributary (1988-93), Catoctin Mountain, Maryland

13. Results of stormflow-hydrograph separations for selected storms, Bear Branch and Fishing Creek tributary watersheds, Catoctin Mountain, Maryland, October 1990 through December 1992 


\section{CONVERSION FACTORS, VERTICAL DATUM, AND ABBREVIATIONS}

\begin{tabular}{rlll}
\hline Multiply & By & To obtain \\
& & & \\
& & \\
micrometer $(\mu \mathrm{m})$ & 0.00003937 & inch \\
millimeter $(\mathrm{mm})$ & 0.03937 & inch \\
meter $(\mathrm{m})$ & 3.281 & foot \\
kilometer $(\mathrm{km})$ & 0.6214 & mile \\
microliter $(\mu \mathrm{L})$ & 0.00003381 & ounce, fluid \\
milliliter $(\mathrm{mL})$ & 0.03381 & ounce, fluid \\
$\operatorname{liter}(\mathrm{L})$ & 33.82 & ounce, fluid \\
milligram $(\mathrm{mg})$ & 0.0000353 & ounce \\
gram $(\mathrm{g})$ & 0.002205 & pound \\
kilogram $(\mathrm{kg})$ & 2.205 & pound \\
hectare $(\mathrm{ha})$ & 2.471 & acre \\
liter per second $(\mathrm{L} / \mathrm{s})$ & 0.03531 & cubic foot per second \\
meter per kilometer $(\mathrm{m} / \mathrm{km})$ & 5.280 & foot per mile \\
& &
\end{tabular}

Sea level: In this report, "sea level" refers to the National Geodetic Vertical Datum of 1929--a geodetic datum derived from a general adjustment of the first-order level nets of the United States and Canada, formerly called Sea Level Datum of 1929.

Abbreviated water-quality units used in this report: Chemical concentrations and water temperature are given only in metric units. Chemical concentration in water is given in microequivalents per liter $(\mu \mathrm{eq} / \mathrm{L})$ or micromoles per liter $(\mu \mathrm{mol} / \mathrm{L})$.

Microequivalents per liter and micromoles per liter are used because they are the most accurate and meaningful units with which to report the chemistry of dilute waters. Microequivalents per liter is a unit expressing the concentration of chemical constituents in solution as equivalent charges (equivalents) of solute per unit volume (liter) of water. One thousand microequivalents per liter is equal to one milliequivalent per liter. Stable-isotope concentration is reported in per mille (per mil), which is equivalent to parts per thousand.

Specific conductance of water is expressed in microsiemens per centimeter at 25 degrees Celsius $(\mu S / \mathrm{cm})$. This unit is equivalent to micromhos per centimeter at 25 degrees Celsius $(\mu \mathrm{mho} / \mathrm{cm})$, formerly used by the U.S. Geological Survey. $\mathrm{pH}$ is given in standard units, which can be converted to microequivalents per liter of hydrogen ion $\left(\mathrm{H}^{+}\right)$by use of the following equation:

$$
\mathrm{pH}=\left[-\log \left(\mathrm{H}^{+}\right)\right]\left[1 \times 10^{6}\right] \text {. }
$$

Temperature is given in degrees Celsius $\left({ }^{\circ} \mathrm{C}\right)$, which can be converted to degrees Fahrenheit $\left({ }^{\circ} \mathrm{F}\right)$ by use of the following equation:

$$
{ }^{\circ} \mathrm{F}=1.8\left({ }^{\circ} \mathrm{C}\right)+32 .
$$


CONVERSION OF UNITS OF CONCENTRATION

Multiply the concentration of ionic chemical species in microequivalents per liter $(\mu \mathrm{eq} / \mathrm{L})$ or micromoles per liter $(\mu \mathrm{mol} / \mathrm{L})$ by the appropriate factor given below to obtain the concentration in milligrams per liter $(\mathrm{mg} / \mathrm{L})$. Concentrations expressed in microequivalents per liter, as they are in this report, are particularly useful when computing cation-anion balances.

\section{Multiply microequivalent By To obtain milligram \\ per liter units: $\quad$ per liter units for:}

$\begin{array}{rll}\text { Hydrogen }\left(\mathrm{H}^{+}\right) & 0.00101 & \mathrm{H}^{+} \\ \text {Calcium }\left(\mathrm{Ca}^{2+}\right) & 0.02004 & \mathrm{Ca}^{2+} \\ \text { Magnesium }\left(\mathrm{Mg}^{2+}\right) & 0.01215 & \mathrm{Mg}^{2+} \\ \text { Sodium }\left(\mathrm{Na}^{+}\right) & 0.02299 & \mathrm{Na}^{+} \\ \text {Potassium }\left(\mathrm{K}^{+}\right) & 0.03910 & \mathrm{~K}^{+} \\ \text {Aluminum }\left(\mathrm{Al}^{3+}\right) & 0.00899 & \mathrm{Al}^{3+} \\ \text { Iron }\left(\mathrm{Fe}^{2+}\right) & 0.02792 & \mathrm{Fe}^{2+} \\ \text { Ammonium }\left(\mathrm{NH}_{4}^{+}\right) & 0.01805 & \mathrm{NH}_{4}^{+} \\ \text {Chloride }\left(\mathrm{Cl}^{+}\right) & 0.03545 & \mathrm{Cl}^{-} \\ \text {Nitrite }\left(\mathrm{NO}_{2}^{-}\right) & 0.04601 & \mathrm{NO}_{2}^{-} \\ \text {Nitrate }\left(\mathrm{NO}_{3}^{-}\right) & 0.06201 & \mathrm{NO}_{3}^{-} \\ \text {Sulfate }\left(\mathrm{SO}_{4}{ }^{-}\right) & 0.04803 & \mathrm{SO}_{4}{ }^{2-} \\ \text { Bicarbonate }\left(\mathrm{HCO}_{3}\right) & 0.06102 & \mathrm{HCO}_{3}{ }^{-} \\ \text {(micromoles per liter) } & 0.06009 & \mathrm{SiO}_{2}\end{array}$




\title{
Hydrologic and Geochemical Factors Affecting the Chemistry of Small Headwater Streams in Response to Acidic Deposition on Catoctin Mountain, North-Central Maryland
}

\author{
By Karen C. Rice and Owen P. Bricker
}

\begin{abstract}
A study was conducted by the U.S. Geological Survey during 1990-93, in cooperation with the Maryland Department of the Environment and the Maryland Department of Natural Resources, to provide an assessment of the susceptibility of small headwater streams to episodic acidification and to evaluate the hydrological and geochemical factors affecting the chemical composition of the streams. Episodic acidification is of environmental concern because it can seriously affect aquatic biota, particularly finfish. The study was focused on two small watersheds in the Blue Ridge Physiographic Province of Maryland, on Catoctin Mountain in Frederick County. The Bear Branch and Fishing Creek tributary watersheds are similar in area, vegetation, land use, soils, geology, precipitation, and direction of streamflow. The watersheds are underlain by the Weverton Formation, a siliciclastic rock type that contains few reactive (weatherable) minerals; therefore, the watersheds are more susceptible to acidification by acidic deposition than are watersheds underlain by more reactive rocks. Hydrologic, geochemical, and isotopic data on precipitation, throughfall, two depths of soil water, shallow ground water, and streamwater during both base-flow and stormflow conditions were collected from and near the

Geochemical data collected from the two watersheds indicate that the streams undergo episodic acidification. During base flow, streams draining these watersheds are slightly acidic ( $\mathrm{pH}$ 5.5-6.5) with a low positive acidneutralizing capacity (5-60 microequivalents per liter). During storms, the $\mathrm{pH}$ of the streams decreases ( $\mathrm{pH}$ sometimes below 5.0), the acidneutralizing capacity decreases, and in Bear Branch, the acid-neutralizing capacity becomes negative. Values of $\mathrm{pH}$ below 5.0 are believed to be harmful to many aquatic organisms. Hydrologic and isotopic data indicate that the changes in streamwater chemistry during stormflow are caused by short, shallow flow paths; that is, waters that have had a short residence time in the watersheds are routed to the streams to become stormflow. The shallow, short residence-time waters generally are acidic because the contact time with watershed materials is short and because the highly weathered, near-surface watershed materials offer little buffering capacity. The streamwater chemistry of the two watersheds studied is typical of watersheds throughout the Blue Ridge Physiographic Province underlain by siliciclastic rocks and of other watersheds, worldwide, underlain by similar rock types.
\end{abstract} watersheds for various periods of time from June 1990 through December 1993. 


\section{INTRODUCTION}

Acidic deposition (or commonly, "acid rain") is a well-known and controversial environmental problem, particularly in the Eastern United States. Acid rain can affect the quality of surface water in two ways: by causing either chronic or episodic acidification. Chronic acidification of surface water results from repeated inputs of acid rain over a period of years, which slowly cause changes in the watershed chemistry so that the stream becomes permanently acidified. A measure of the degree of acidification of a stream is its acid-neutralizing capacity (ANC), where a large value for the ANC indicates that the water is not acidified, and where an ANC of less than or equal to zero indicates acidification. Episodic acidification of a stream occurs over a relatively short time period (hours or days) as a result of an individual rainstorm or snowmelt and causes a temporary decrease in water $\mathrm{pH}$ and ANC. Most water bodies that are underlain by rock types that weather slowly and where episodic acidification takes place, eventually will become chronically acidified (Wigington and others, 1990).

Episodic acidification is an environmental concern because the short-term changes in streamwater chemistry can have detrimental effects on aquatic organisms, including finfish, even though the streamwater chemistry is generally suitable for most of the year (Baker and others, 1990). Episodic acidification in streams throughout the United States, Canada, and Europe has been well documented (Wigington and others, 1990, and references therein; Rice and Bricker, 1992a; O'Brien and others, 1993). Although episodic acidification is widespread, the exact watershed mechanisms that are responsible for episodic acidification are not well understood. This report summarizes research on the occurrence and causes of episodic acidification of two small watersheds in the Blue Ridge Physiographic Province of Maryland.

Small watersheds (those with an area less than 200 ha) are ideal study units because (1) it is less difficult to measure the inputs by atmospheric deposition and the exports by surface runoff in small basins than in large basins; (2) small watersheds are less likely to be affected by anthropogenic disturbances other than those that affect atmospheric deposition, such as agricultural activity, deforestation, development, and wastewater disposal, than are large basins; (3) small watersheds may be confined to single bedrock types, simplifying the identification of watershed sources of dissolved solutes; (4) much research has been done on small forested watersheds aimed at understanding streamflowgeneration mechanisms and the biogeochemistry of throughfall, soil water, ground water, and surface runoff; and (5) results of research on small watersheds could be extrapolated to larger basins for the determination of more regional effects of atmospheric deposition.

The Middle Atlantic States receive some of the most acidic precipitation in the Nation (U.S. National Acid Precipitation Assessment Program, 1991). The State of Maryland has recognized the importance of acidic deposition in the region and its effects on the quality of its waters and the health of its aquatic resources. Four streamwater-quality studies conducted in Maryland (Janicki and Cummins, 1983; Janicki and Greening, 1987; Knapp and others, 1988a, 1988b) prompted the State legislature in July 1989 to establish the Maryland Department of the Environment (MDE) Stream Acidification Monitoring Program (SAMP), which has three components: (1) a longterm trend study; (2) a yearly survey; and (3) a biological monitoring component. For these reasons, two small watersheds in the Blue Ridge Physiographic Province of Maryland were chosen by the U.S. Geological Survey (USGS) for intensive instrumentation and water-quality monitoring to assess the effects of episodic acidification in those watersheds. This study, begun in 1990, was done as a joint-funding agreement between the MDE, the State of Maryland's Department of Natural Resources (DNR), and the USGS. The watershed sites established for the USGS study have been incorporated as part of MDE's SAMP long-term trend study. 


\section{Purpose and Scope}

The purpose of this report is to describe and interpret the hydrologic and geochemical factors that affect the water chemistry of two headwater streams in response to acidic deposition on Catoctin Mountain in north-central Maryland. The report includes discussions of (1) the chemical and isotopic composition of precipitation, throughfall, soil water, shallow ground water, and streamwater in the monitored watersheds; (2) the changes in streamwater chemistry from base flow to stormflow in the monitored watersheds; (3) the geochemical processes in the monitored watersheds that affect the base-flow chemistry of the streams; (4) the components of stormflow in the monitored watersheds identified by use of hydrologic, chemical, and stable-isotope data; (5) the extent to which these monitored watersheds are affected by acidic deposition and their sensitivity to changes in acidic deposition; and (6) the characteristics of small watersheds that could make them predisposed to chronic and (or) episodic acidification.

The study was designed to evaluate the effects of episodic acidification on the water quality of two headwater streams on Catoctin Mountain. Hydrologic, geochemical and isotopic data were collected from both watersheds over a 31 / 2-year period (June 1990 through December 1993). These data were used to assess the effects of episodic acidification and to identify some of the watershed mechanisms responsible for the observed episodic acidification. The network design, sampling procedures, and analytical methods are given in the "Methods" section of the report.

\section{Location and Physical Setting of Study Area}

The study area is located on Catoctin Mountain near the town of Thurmont in the northwestern part of Frederick County, north-central Maryland (fig. 1). This region of Maryland is situated in the Blue Ridge Physiographic Province of the Appalachian Highlands division (Fenneman, 1946). The Blue Ridge Physiographic Province is characterized, in general, by ancient crystalline rocks. In Maryland, the Blue Ridge Physiographic Province comprises Catoctin Mountain, a northeast-trending anticlinal ridge with a Precambrian core. The Precambrian core consists of the Catoctin Formation and is flanked by rocks of Cambrian age. The flanks of Catoctin Mountain consist of the Loudoun, Weverton, and Harpers Formations, and colluvial material derived from those formations.

The two watersheds that are the focus of this study are located on the eastern flank of Catoctin Mountain (fig. 2). The streams that flow through the watersheds are Bear Branch and an unnamed tributary to Fishing Creek. For simplicity, in this report, the streams and their corresponding watersheds will be referred to as "Bear Branch" and "Fishing Creek tributary." Bear Branch is located approximately $3 \mathrm{~km}$ west of the town of Thurmont, and Fishing Creek tributary is located approximately $10 \mathrm{~km}$ south of Bear Branch and approximately $3 \mathrm{~km}$ west of the town of Lewistown. Both streams drain to the Monocacy River, a tributary of the Potomac River. The Potomac River is a major tributary of Chesapeake Bay.

The climate in north-central Maryland is humid and temperate, and the long-term (1931-80) average annual air temperature and average annual amount of precipitation were $12^{\circ} \mathrm{C}$ and $1,110 \mathrm{~mm}$, respectively (National Oceanic and Atmospheric Administration, 1981). Precipitation at Catoctin Mountain from 1982 to 1993 was fairly evenly distributed throughout the year, with a maximum of $139 \mathrm{~mm}$ in May and a minimum of $67 \mathrm{~mm}$ in January. The amount of snowfall each winter on Catoctin Mountain varies from year to year but commonly totals less than $0.5 \mathrm{~m}$. There is usually no significant snowpack development; consequently, high spring runoff from snowmelt does not occur.

Bear Branch is located on State-designated wild lands within Cunningham Falls State Park. Bear Branch is a small, eastward-flowing headwater stream that flows perennially, with an average (1991-93) mean daily discharge of $19 \mathrm{~L} / \mathrm{s}$. The 98 ha watershed is forested with deciduous and coniferous trees; the ratio of deciduous to coniferous coverage is approximately $9: 1$. The area is utilized as parkland where only day hiking and hunting are 


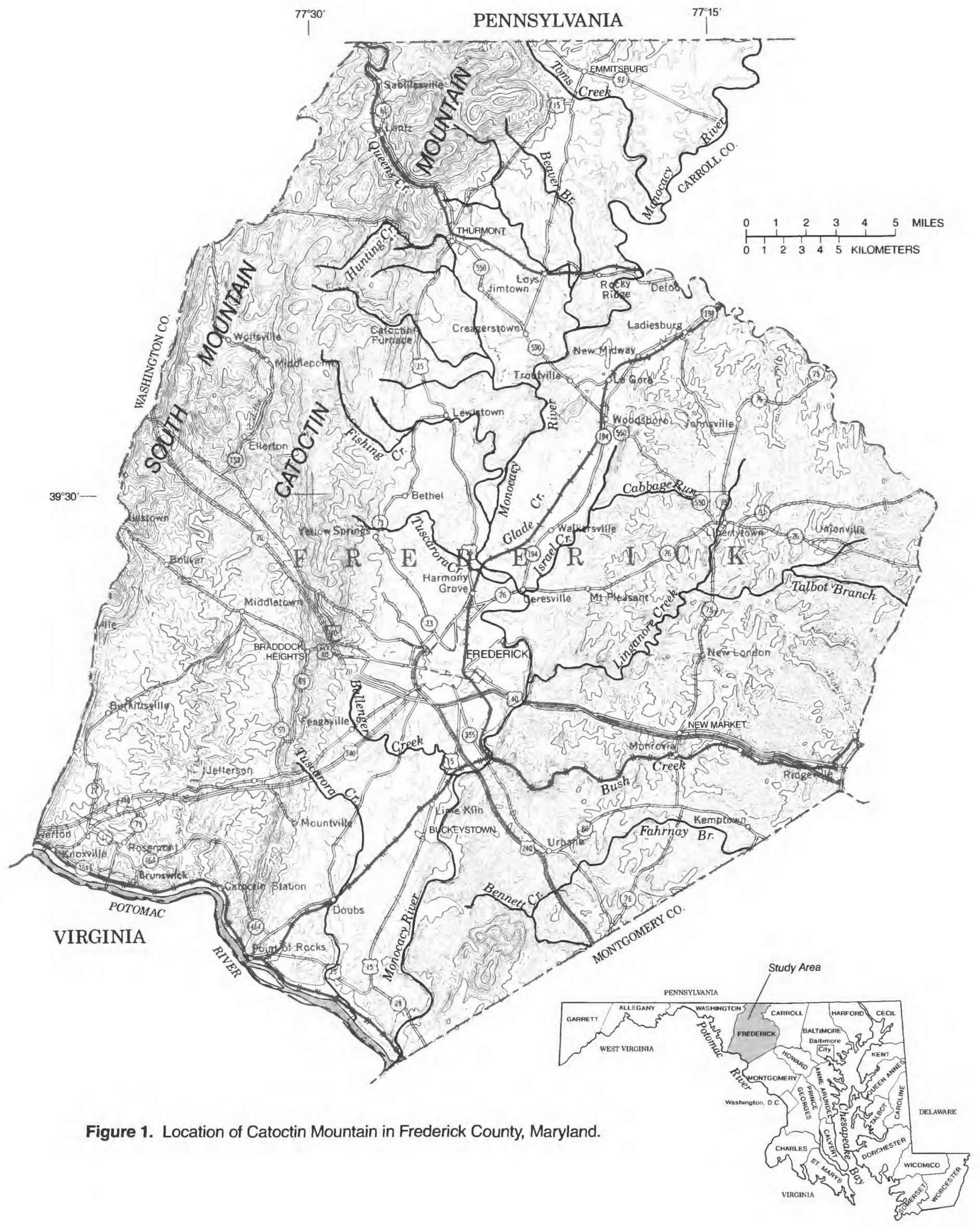




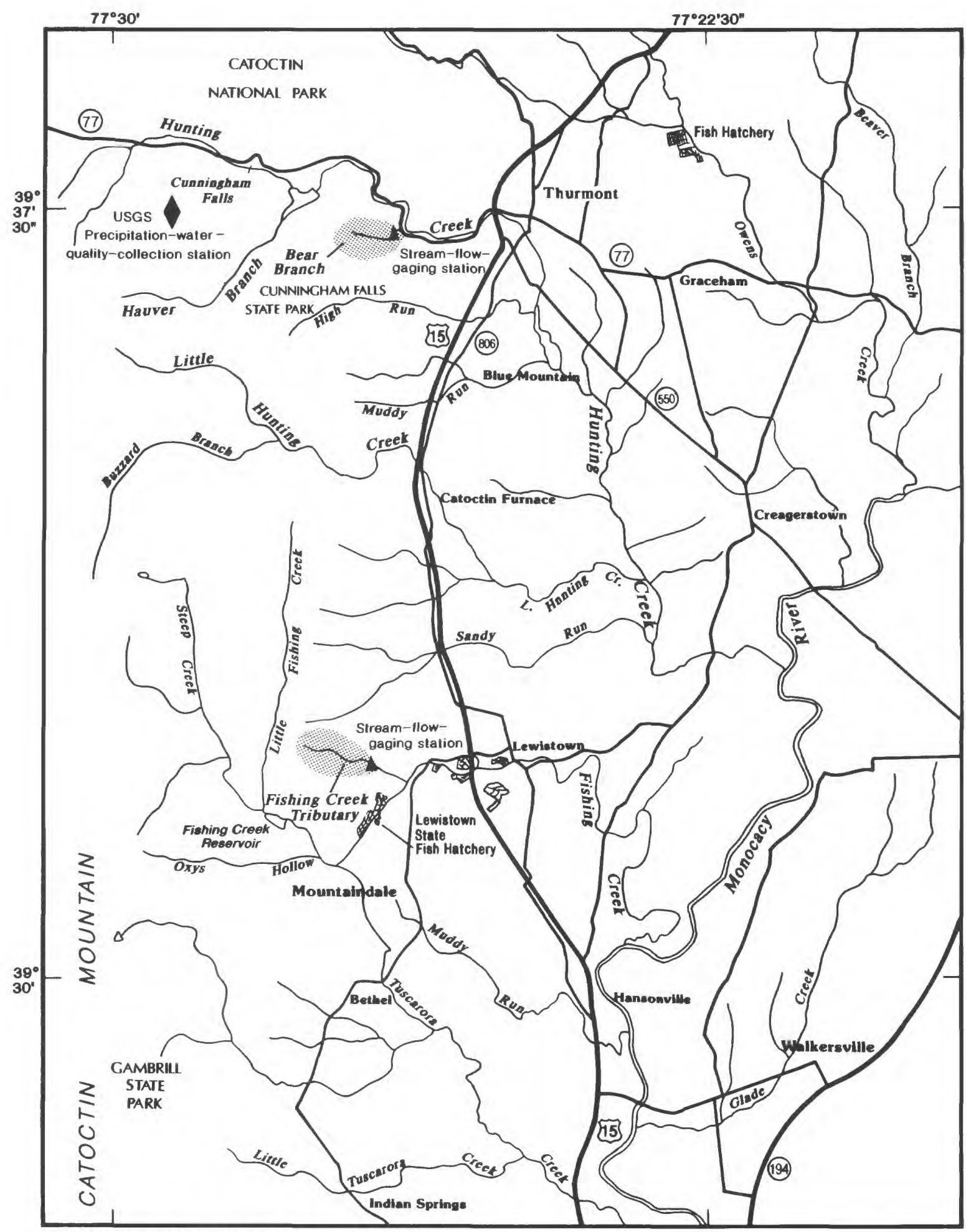

Base Map from U.S. Geological Survey, 1:100,000

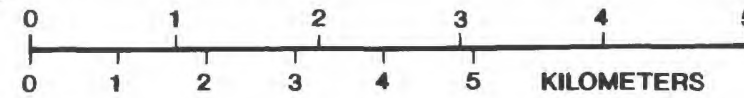

Figure 2. Location of study area on Catoctin Mountain, Maryland. 
allowed. The topography is steep and rocky, and the average stream gradient is $203 \mathrm{~m} / \mathrm{km}$ (20 percent). Altitudes of the land surface range from $233 \mathrm{~m}$ at the streamflow-gaging station to $500 \mathrm{~m}$ at the top of the watershed divide. The watershed is underlain entirely by the lower unit of the Weverton Formation (Fauth, 1977). The soils consist of Ultisols and Inceptisols and are mapped as the Edgemont-Chandler series complex, which is characterized as very stony loams with 20 - to 60 -percent slopes (Matthews, 1960).

Fishing Creek tributary is located partly on State-owned fish hatchery property and partly on privately owned forest land. Fishing Creek tributary is a small, eastward-flowing, perennial headwater stream, with an average (1991-93) mean daily discharge of $19 \mathrm{~L} / \mathrm{s}$. The 104-ha watershed is 100 percent forested with deciduous trees and evergreen shrubs. The topography is moderately steep and rocky, and the average stream gradient is $118 \mathrm{~m} / \mathrm{km}$ (12 percent). A relatively flat, boulder-filled area is located just upstream of the streamflow-gaging station. Altitudes of the land surface range from $165 \mathrm{~m}$ at the streamflow-gaging station to $391 \mathrm{~m}$ at the top of the watershed divide. The watershed is underlain entirely by the upper unit of the Weverton Formation (Fauth, 1977). The soils consist of Ultisols and Inceptisols and are mapped as the

Edgemont-Chandler series complex, which consists of very stony loams with 0 - to 20 -percent and 20to 60-percent slopes, and as the Braddock series complex, which is characterized as moderately eroded gravelly and cobbly loams with 8 - to 15 -percent slopes (Matthews, 1960). A few trees in the watershed were harvested during the study, which allowed an approximate estimate of the age of the forest. Most of the cut trees were about 70 years old; one tree was 96 years old.

Bear Branch and Fishing Creek tributary watersheds are very similar with respect to watershed area, vegetation, land use, soils, geology, acidic precipitation input, and direction of streamflow. Neither watershed is affected by agricultural activity. No human-induced factors affecting streamwater quality in the Bear Branch watershed have been identified. The only possible human-induced factors affecting streamwater quality in the Fishing Creek tributary watershed are several summer cab- ins, a few dirt roads, and some minor timber harvesting. The largest difference between the two watersheds is the topography; the Bear Branch watershed is much steeper than the Fishing Creek tributary watershed. The physical characteristics of the two watersheds are summarized in table 1.

\section{Previous Investigations}

Data collection and research have been conducted at Catoctin Mountain, Maryland, since 1982 and have continued through the present (1995). Precipitation- and streamwater-quality monitoring were funded initially by the National Acid Precipitation Assessment Program (NAPAP), which provided funding for two precipitation-collection stations and three streamwater-quality monitoring stations. During 1985, one of the precipitationcollection stations and one of the streamwaterquality monitoring stations were discontinued, and during 1987 , streamwater-quality monitoring was initiated at an additional station. During 1990, funding for precipitation- and streamwater-quality monitoring was augmented by cooperative agreements between the USGS and the MDE and DNR. Research on episodic acidification of streams on Catoctin Mountain was completed as part of these agreements. This report summarizes the research on episodic acidification of two streams on Catoctin Mountain.

Research on hydrologic and geochemical processes in small watersheds on Catoctin Mountain is reported in Katz and others (1985), Trombley and Zynjuk (1985), Bricker and Rice (1989), Katz (1989), Kendall and others (1992), Acker and Bricker (1992), O'Brien and others (1993, in press), and Rice and Bricker (1993, 1995a). Reports on Catoctin Mountain research activities written specifically for lay readers are Rice and Bricker (1992a, 1992b, 1995b). Results of data-collection activities only (no interpretation) at Catoctin Mountain can be found in Rice and others (1993, 1996, in press). 
Table 1. Physical characteristics of the Bear Branch and Fishing Creek tributary watersheds, Catoctin Mountain, Maryland [ha, hectares; $\mathrm{m}$, meters; $\mathrm{m} / \mathrm{km}$, meters per kilometer; \%, percent]

\begin{tabular}{|c|c|c|}
\hline Physical characteristics & Bear Branch & Fishing Creek tributary \\
\hline Watershed area (ha) & 98 & 104 \\
\hline $\begin{array}{l}\text { Direction of } \\
\text { streamflow }\end{array}$ & East & East \\
\hline Formation name & Weverton, lower unit & Weverton, upper unit \\
\hline $\begin{array}{l}\text { Bedrock } \\
\text { lithology }\end{array}$ & $\begin{array}{l}\text { Quartzite with } \\
\text { phyllite interbeds }\end{array}$ & $\begin{array}{l}\text { Quartzite with } \\
\text { phyllite interbeds }\end{array}$ \\
\hline $\begin{array}{l}\text { Mineralogy of } \\
\text { bedrock }\end{array}$ & $\begin{array}{l}\text { Quartz, potassic feldspar, } \\
\text { chlorite, sericite, opaques }\end{array}$ & $\begin{array}{l}\text { Quartz, potassic feldspar, } \\
\text { chlorite, sericite, opaques }\end{array}$ \\
\hline $\begin{array}{l}\text { Altitude of } \\
\text { streamflow-gaging } \\
\text { station (m) }\end{array}$ & 233 & 165 \\
\hline $\begin{array}{l}\text { Highest point } \\
\text { in watershed (m) }\end{array}$ & 500 & 391 \\
\hline $\begin{array}{l}\text { Gradient of } \\
\text { stream }(\mathrm{m} / \mathrm{km})\end{array}$ & 203 & 118 \\
\hline Vegetation & $\begin{array}{l}90 \% \text { deciduous } \\
10 \% \text { coniferous }\end{array}$ & $100 \%$ deciduous \\
\hline Soil series ${ }^{1}$ & $\begin{array}{l}\text { Edgemont-Chandler very } \\
\text { stony loams, } 20-60 \% \text { slopes }\end{array}$ & $\begin{array}{l}\text { Edgemont-Chandler very stony loams, } \\
0-20 \% \text { and } 20-60 \% \text { slopes; Braddock } \\
\text { gravelly and cobbly loams, } 8-15 \% \\
\text { slopes, moderately eroded }\end{array}$ \\
\hline
\end{tabular}

${ }^{1}$ From Matthews (1960). 


\section{Acknowledgments}

The authors would like to thank the Maryland Department of Natural Resources for allowing the precipitation-collection station and the instrumentation in the Bear Branch watershed to be maintained on Cunningham Falls State Park property and for the instrumentation in the Fishing Creek tributary watershed to be maintained on Lewistown State Fish Hatchery property. The authors also would like to thank William D. Miller of Cunningham Falls State Park and Michael A. Shaw and Raymond M. Richardson of the Lewistown State Fish Hatchery for providing information and assistance whenever it was needed. Appreciation is given to Karl C.Weaver of the MDE and Paul E. Miller of the DNR for their reviews of this report. The authors would also like to thank Kathleen M. Buppert, a former MDE employee, for her assistance in data collection.

\section{METHODS}

Detailed descriptions of the watershed instrumentation, data-collection techniques, sample preparation, and laboratory methods are published in a separate data report (Rice and others, 1996, in press). In this report, only a brief overview of the methods used in this study is given.

\section{Watershed Instrumentation}

The USGS Catoctin Mountain precipitationcollection station, located in Cunningham Falls State Park approximately 3,000 m west of the Bear Branch watershed, has been in operation since January 1982 (fig. 2). The precipitation-collection equipment is situated on top of a 7.6-m high waterstorage tank and is free of surrounding tree canopy, which meets the National Acid Deposition Program (NADP) angle criteria (Robertson and Wilson, 1985). The collection equipment includes an Aerochem Metrics ${ }^{1}$ Model 301 wet/dry atmosphericdeposition collector, a Belfort 5-780 Series weigh-

\footnotetext{
${ }^{1}$ Any use of trade, product, or firm names is for descriptive purposes only and does not constitute endorsement by the U.S. Geological Survey.
}

ing-bucket rain gage, and from June 1990 to the present, a Sierra Misco Model ES-160 tippingbucket rain gage. The collection equipment is anchored to a 2-m tall wooden platform on top of the water tank. The elevated equipment serves to minimize contamination of the samples by "splash up" from the top of the water tank and to discourage vandalism. The weighing- and tipping-bucket rain gages measure the quantity of precipitation that falls at the precipitation-collection station and record the time and duration of rainfall. More details on the precipitation-collection station instrumentation can be found in Rice and others (1993, 1996 , in press).

To implement this study in June 1990, each watershed was equipped with a variety of instrumentation. Instrumentation included a staff gage and Fisher Porter analog-to-digital recorder, a Campbell Scientific CR10 data logger, a stream-stage potentiometer, an ISCO Model 2700 automatic water sampler, a Sierra Misco Model ES-160 tipping-bucket rain gage, a solar panel and voltage regulator, a shelter to house this equipment, throughfall collectors, zero-tension soil lysimeters, and a series of shallow ground-water well points. The Campbell Scientific CR10 data loggers used at each site recorded the streamwater levels sensed by the stage potentiometer, controlled the ISCO automatic sampler, and recorded the number of tips made by the tipping-bucket rain gage.

The staff gage and analog-to-digital recorder in each watershed were used to determine and record stream stage near the outlet of the watersheds (fig. 3 and 4). Natural controls in the streams provided a pool where the staff gage could be located. The stream stage was recorded on paper tape at 15minute intervals by the Fisher Porter analog-todigital recorder. Every 6 weeks the paper tape was removed, and a discharge measurement of the stream was made according to methods described in Buchanan and Somers $(1968,1969)$. The streamstage data and the periodic discharge measurements were used to develop log-log rating curves, with coefficient of determination $\left(\mathrm{r}^{2}\right)$ values ranging from 0.893 to 0.997 , from which instantaneous stream discharges were calculated according to methods described in Kennedy $(1983,1984)$. Be- 
cause of erosion of the natural control on Fishing Creek tributary, a $90^{\circ} \mathrm{V}$-notch stainless-steel weir plate was installed on April 14, 1992. The weir plate helped stabilize the stage-discharge relation at that site.

Throughfall collectors used for collecting precipitation that falls through the forest canopy were installed in each watershed. The collectors consisted of a 203-mm-diameter polyethylene funnel connected to a 1-L brown polyethylene collection bottle by Tygon tubing with a loop to prevent evaporation of the sample. Each collector had a plastic rain gage connected to it to give an approximate measure of the amount of throughfall collected at each site. The funnels were located approximately $1.2 \mathrm{~m}$ above land surface to help minimize "splash up" from the forest floor. In the Bear Branch watershed, three collectors were located beneath the canopies of deciduous trees, and three collectors were located beneath the canopies of coniferous trees (fig. 3). In the Fishing Creek tributary watershed, three collectors were located beneath the canopies of deciduous trees (fig. 4).

Zero-tension soil lysimeters, for the collection of soil water, were installed near the streams. Two lysimeter pits were hand dug in each watershed. The lysimeters consisted of shallow $229-\mathrm{mm}$ by 279-mm polyethylene pans, filled with polyethylene beads to prevent the pans from filling with soil, with a drain hole at one end. Two pans were inserted at a slight upward angle $\left(5^{\circ}\right.$ to $\left.10^{\circ}\right)$ into the vertical wall of the dug soil pit at each level, and the soil water collected in the pans drained by gravity to a 19-L polyethylene carboy. In the Bear Branch watershed, pit 1was dug into the steep north bank of the stream, and pit 2 was dug into the less steep south bank (fig. 3). In each pit, the two upper pans were located beneath the organic-litter layer at a depth of 0.10 to $0.15 \mathrm{~m}$ below land surface, and the two lower pans were located between 0.46 and 0.51 $\mathrm{m}$ below land surface. In the Fishing Creek tributary watershed, two lysimeter pits were dug into the steeper south bank of the stream (fig. 4). In both pits, the two upper pans were located beneath the organic-litter layer at a depth of 0.10 to $0.15 \mathrm{~m}$ below land surface. The two lower pans in pit 1 were located at a depth of $0.51 \mathrm{~m}$, whereas the lower pans in pit 2 were located at a depth of 0.91 $\mathrm{m}$ and a third set of pans was installed at a depth of $1.37 \mathrm{~m}$ below land surface.

Shallow ground-water well points were installed at each site by hand driving with a sledgehammer. The well points were used to monitor the depth of the water table and to sample shallow ground water. The well-point casings were constructed of 50-mm-diameter, schedule- 40 stainless steel; the screens were 304 stainless steel with a slot size of $0.254 \mathrm{~mm}$. All well points were capped with stainless-steel caps. In the Bear Branch watershed, four well points were installed along a line perpendicular to the stream (fig. 3); screen depths ranged from 0.48 to $2.69 \mathrm{~m}$ below land surface. In the Fishing Creek tributary watershed, two well points were installed (fig. 4); screen depths ranged from 0.13 to $0.93 \mathrm{~m}$ below land surface.

\section{Data-Collection Techniques}

Precipitation samples were collected weekly, if available, from the Aerochem Metrics precipitation-collection station for chemical and isotopic analysis. The chart from the weighingbucket rain gage was changed, and the wet-precipitation collection bucket for the Aerochem Metrics collector was replaced with a clean bucket that had been rinsed with distilled water. Total daily, monthly, and annual amounts of precipitation from the weighing-bucket rain gage were recorded. The data-storage module, which held the tipping-bucket rain-gage data at the station, was exchanged with an empty data-storage module, and the data were downloaded to a computer in the office.

Throughfall was collected on a weekly basis so that the data set included individual storms as well as composites of more than one storm. Each week, all collectors were visited, and the amount of rainfall was recorded. Samples from the throughfall collector were added to a $3.8-\mathrm{L}$ plastic jug; the jug held a composite sample from the three throughfall collectors. The funnels and throughfall collection bottles then were thoroughly rinsed with distilled water in preparation for the next rainstorm. 


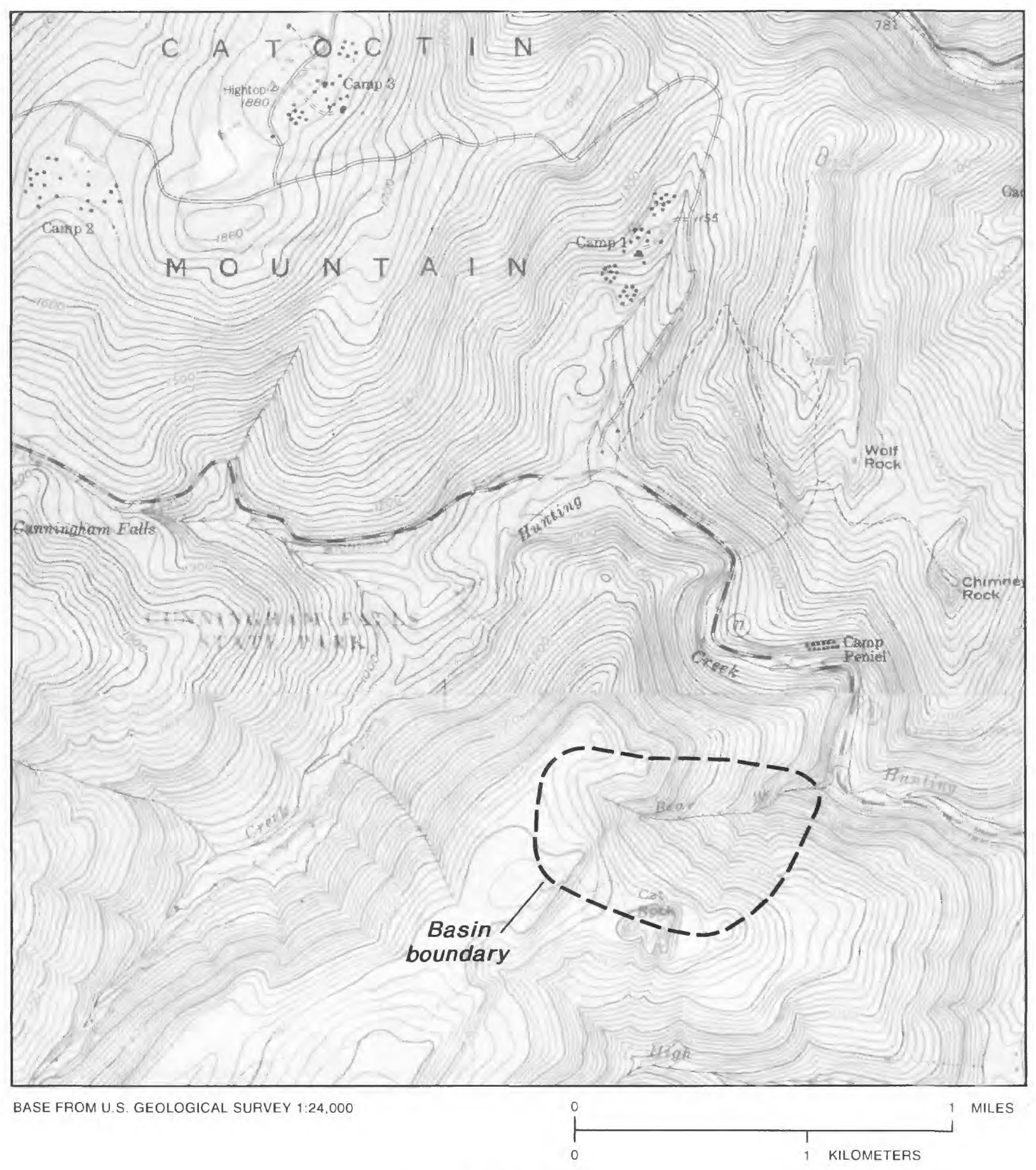

EXPLANATION

- 600 - TOPOGRAPHIC CONTOUR - shows equal altitude of land surface. Contour interval is 20 feet. Datum is sea level.

Figure 3. Topography and instrumentation in the Bear Branch watershed, Catoctin Mountain, Maryland. 


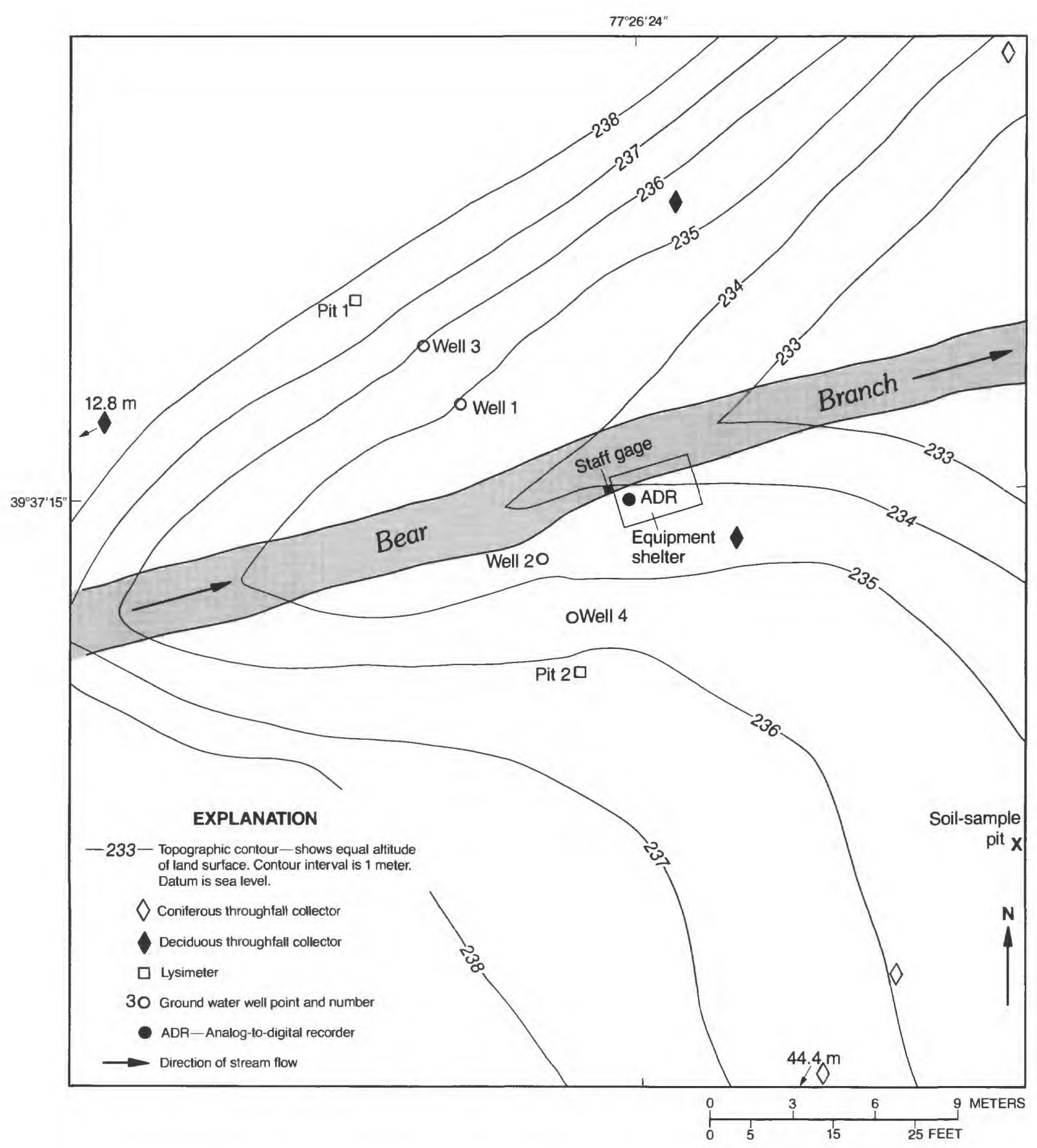

Figure 3. Topography and instrumentation in the Bear Branch watershed, Catoctin Mountain, Maryland--Continued. 


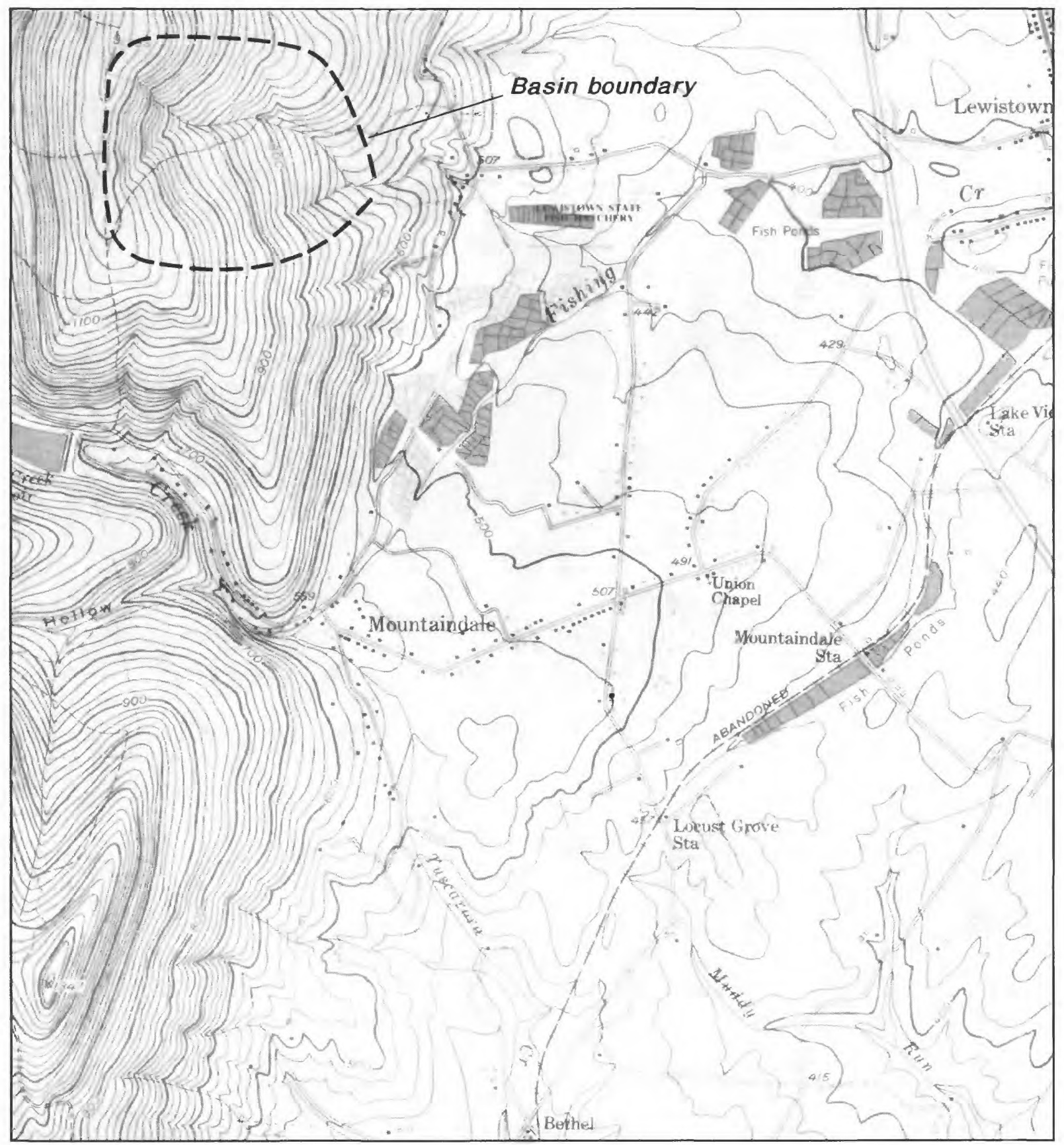

BASE FROM U.S. GEOLOGICAL SURVEY 1:24,000

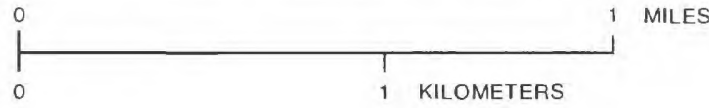

EXPLANATION

- 600 - TOPOGRAPHIC CONTOUR - shows equal altitude of land surface. Contour interval is 20 feet. Datum is sea level.

Figure 4. Topography and instrumentation in the Fishing Creek tributary watershed, Catoctin Mountain, Maryland. 


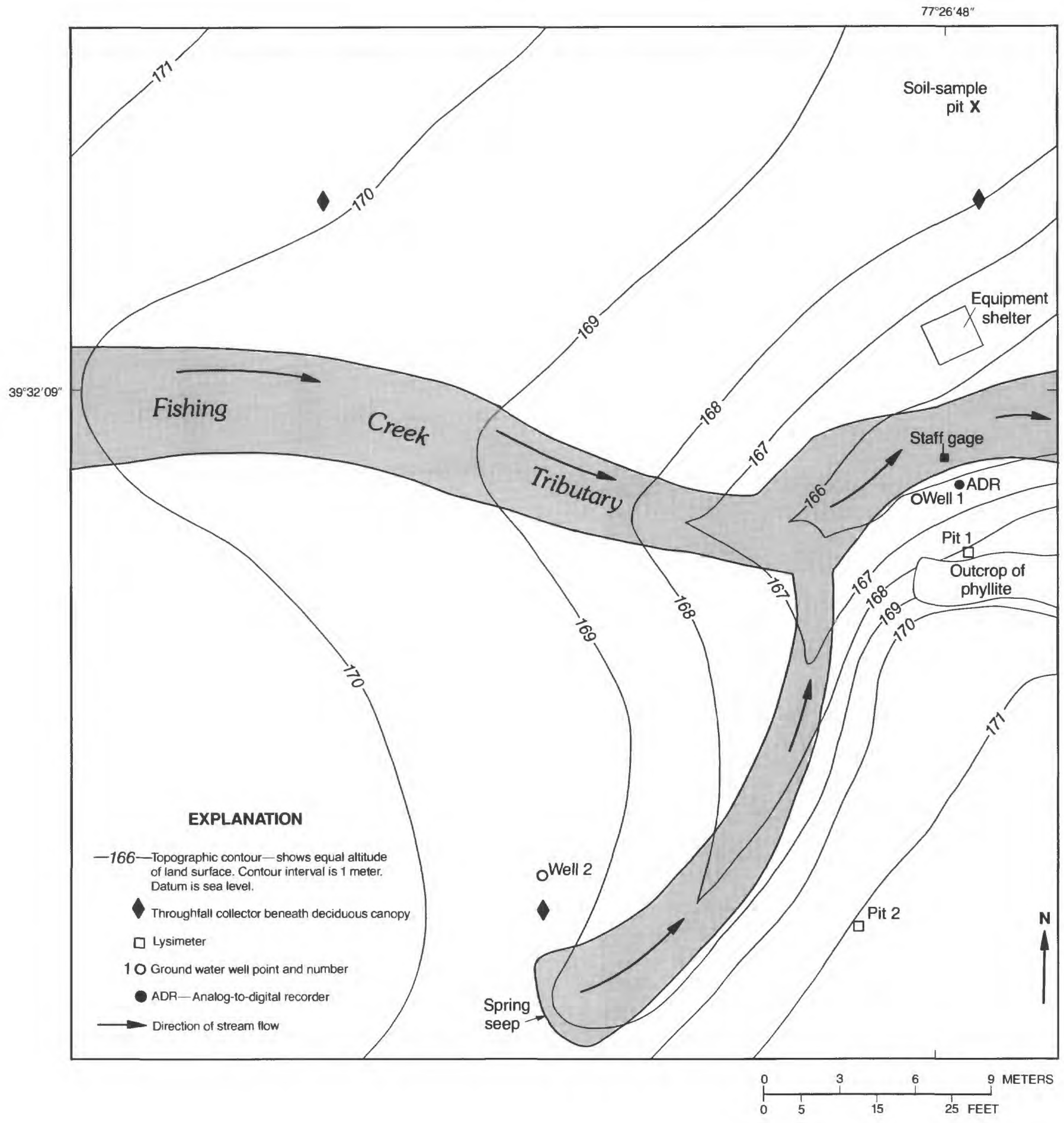

Figure 4. Topography and instrumentation in the Fishing Creek tributary watershed, Catoctin Mountain, Maryland-Continued. 
Water in the zero-tension soil lysimeters was withdrawn and a sample was collected whenever stormflow samples had been collected by the ISCO automatic sampler. During periods when no stormflow samples were collected by the ISCO automatic sampler, the lysimeter carboys were emptied every 2 to 4 weeks, which usually allowed enough time to ensure that sufficient sample for chemical and isotopic analysis could be retrieved. Therefore, the lysimeter samples were generally a composite of more than one rainstorm. The water in the lysimeters was withdrawn using a portable Masterflex peristaltic pump. The tubing from the carboy that led up to the land surface was connected to the silicon tubing on the peristaltic pump, and the sample was pumped by suction to the surface and into a 3.8-L jug. A different 3.8-L jug was used for each level of lysimeter pans in each pit. The tubing in the peristaltic pump was rinsed with distilled water after each carboy was pumped dry. Both carboys in each pit were pumped dry in preparation for the next rainstorm.

Shallow ground-water samples during periods of stream base flow were collected periodically from the well points at each site and from a perennially discharging spring in the Fishing Creek tributary watershed. Water levels in the well points were measured weekly using the wetted-steel-tape method (Kazmann, 1965).

Streamwater grab samples were collected from each watershed on a weekly and biweekly basis during the study period. The samples were collected from a point of maximum flow in the stream near the streamflow-gaging station. Samples from Bear Branch were collected weekly from June 1990 to April 1992, whereas samples from Fishing Creek tributary were collected weekly from October 1987 to April 1992. Starting in April 1992, streamwater samples from both watersheds were collected biweekly.

Stormflow samples were collected automatically with an ISCO automatic sampler controlled by a CR10 data logger. The stormflow-sampling setup was similar to that described by Peters (1994) and is described in more detail for these sites in Rice and others (1996, in press). Stormflow samples were retrieved on a weekly basis and sometimes on a per storm basis. At that time, the bottles containing the stormflow samples were replaced with a spare set of clean ISCO bottles. The data-storage module connected to the CR10 was exchanged with an empty data-storage module, and the data were downloaded to a computer in the office.

Precipitation, throughfall, and soil-water samples were analyzed on site for specific conductance and $\mathrm{pH}$, and ground-water and streamwater samples were analyzed on site for specific conductance, $\mathrm{pH}$, and temperature. Specific conductance was measured for a sample with a YSI model 34 conductance-resistance meter, a model 3417 conductivity cell, and a temperature compensator. The performance of the conductivity cell was checked on the day of the sampling in standard specific-conductance solutions, which indicated that the specific-conductance measurements were accurate to $\pm 3 \mu \mathrm{S} / \mathrm{cm}$. Sample $\mathrm{pH}$ 's were measured with a Beckman Phi 31 meter, an Orion Ross glass combination electrode, and a Beckman temperature compensator. The $\mathrm{pH}$ electrode was calibrated at the beginning of the sampling day with standard buffer solutions of $\mathrm{pH} 7.0$ and 4.0. The buffers were diluted approximately 50 percent by the addition of distilled water to "sensitize" the electrode to the lowionic-strength water it was to measure. The calibration of the electrode then was checked in $10^{-4}$ normal $\mathrm{H}_{2} \mathrm{SO}_{4}$ (sulfuric acid) $(\mathrm{pH}=4.0)$, which indicated that the $\mathrm{pH}$ measurements were accurate to $\pm 0.05 \mathrm{pH}$ unit. The electrode was calibrated two or more times during long sampling days. Water temperature was measured in the well points and streams with a mercury-filled thermometer, calibrated in degrees Celsius.

\section{Sample Preparation}

Precipitation, throughfall, soil-water, groundwater, and streamwater samples were filtered immediately after collection through $0.1-\mu \mathrm{m}$ (micron) pore-size cellulose-nitrate filters by using positive pressure created by a peristaltic pump. Each sample was split into two aliquots: a filtered, acidified (FA) sample and a filtered, chilled (FC) sample. The FA sample was prepared by filtering approximately $125 \mathrm{~mL}$ of sample into a $250-\mathrm{mL}$ white 
polyethylene bottle that had been rinsed with nitric acid; then $200 \mu \mathrm{L}$ of Baker's InstrAnalyzed nitric acid were pipetted into the sample bottle. The addition of nitric acid acidified the sample to a pH of less than 2.0 and served to preserve the sample. The FA sample was delivered to the laboratory where it was analyzed for cation and silica concentrations. The FC sample was prepared by filtering approximately $120 \mathrm{~mL}$ of sample into a $125-\mathrm{mL}$ brown polyethylene bottle that had been rinsed three times with filtered sample water; the sample was transported on ice and stored at $4^{\circ} \mathrm{C}$ in the laboratory. The brown bottle, the filtration, and the chilled storage served to decrease the activity of organisms that can cause the chemistry of the sample to change. The FC sample was delivered to the laboratory, where it was analyzed for $\mathrm{pH}$, the $\mathrm{ANC}$, and anion concentrations. Stormflow samples were filtered and prepared in the same way, but the measurement of specific conductance and $\mathrm{pH}$ and the sample preparation were generally done the day after sample collection.

Samples for analysis of the stable isotopes deuterium (D) and oxygen-18 $\left({ }^{18} \mathrm{O}\right)$ were collected for all types of water in the watersheds. Sixty milliliters of unfiltered sample were decanted into a flintglass bottle with a polyseal cap. No preservative was added. The bottle caps were covered with Parafilm laboratory wax paper to further ensure against evaporation of the sample.

\section{Laboratory Methods}

Water samples collected for the determination of major inorganic ion concentrations were sent to the USGS trace elements and nutrients laboratory in Reston, Va. Precipitation samples were analyzed in the laboratory for concentrations of dissolved calcium $\left(\mathrm{Ca}^{2+}\right)$, magnesium $\left(\mathrm{Mg}^{2+}\right)$, sodium $\left(\mathrm{Na}^{+}\right)$, potassium $\left(\mathrm{K}^{+}\right)$, ammonium $\left(\mathrm{NH}_{4}^{+}\right)$, chloride $\left(\mathrm{Cl}^{-}\right)$, nitrite $\left(\mathrm{NO}_{2}{ }^{-}\right)$, nitrate $\left(\mathrm{NO}_{3}{ }^{-}\right)$, sulfate $\left(\mathrm{SO}_{4}{ }^{2-}\right)$, and for $\mathrm{pH}$ (for quality-assurance purposes). Samples of throughfall, soil water, ground water, and streamwater were analyzed for $\mathrm{Ca}^{2+}, \mathrm{Mg}^{2+}, \mathrm{Na}^{+}, \mathrm{K}^{+}, \mathrm{Cl}^{-}$, $\mathrm{NO}_{2}^{-}, \mathrm{NO}_{3}^{-}, \mathrm{SO}_{4}{ }^{2-}$, bicarbonate $\left(\mathrm{HCO}_{3}^{-}\right)$, silicon (reported as $\mathrm{SiO}_{2}$ ), total aluminum, and iron, and for $\mathrm{pH}$ (for quality-assurance purposes). Laboratory analysis methods and minimum detection limits are summarized in table 2. Concentrations of each constituent were reported to the minimum detection limit; if the constituent was not detected in the sample, a "<" (less than) the detection limit was reported, and one-half of the detection limit was used in statistical calculations of the data.

FA samples were analyzed for concentrations of dissolved $\mathrm{Ca}^{2+}, \mathrm{Mg}^{2+}, \mathrm{Na}^{+}, \mathrm{K}^{+}, \mathrm{Si}$ (reported as $\mathrm{SiO}_{2}$ ), and total aluminum and iron. $\mathrm{FC}$ samples were analyzed for concentrations of dissolved $\mathrm{NH}_{4}{ }^{+}, \mathrm{Cl}^{-}, \mathrm{NO}_{2}{ }^{-}, \mathrm{NO}_{3}{ }^{-}, \mathrm{SO}_{4}{ }^{2-}$, and ANC. Laboratory $\mathrm{pH}$ of these samples was determined for qualityassurance purposes. The $\mathrm{pH}$ range of the samples analyzed (4.0-6.8) suggested that the $\mathrm{Al}^{3+}$ form of aluminum and the $\mathrm{Fe}^{2+}$ form of iron were the most abundant species (iron oxidation to $\mathrm{Fe}^{3+}$ is very slow, kinetically, at low $\mathrm{pH}$ ).

Dissolved concentrations of $\mathrm{Cl}^{-}, \mathrm{NO}_{2}{ }^{-}, \mathrm{NO}_{3}{ }^{-}$, and $\mathrm{SO}_{4}{ }^{2-}$ were determined with a Dionex $2110 \mathrm{i}$ ion chromatograph. A Dionex 100DX ion chromatograph with Waters Maxima 820 computer program was used to determine $\mathrm{NH}_{4}{ }^{+}$concentrations. Dissolved concentrations of $\mathrm{Ca}^{2+}, \mathrm{Mg}^{2+}, \mathrm{Na}^{+}, \mathrm{K}^{+}$, aluminum, iron, and $\mathrm{Si}$ were determined with an ARL Spectra Span V DCP-A (DCP).

The ANC can be defined operationally as the equivalent sum of the bases that can be titrated with a strong acid to a determined equivalence point. It measures the net deficiency of protons, which can include noncarbonate contributions such as ammonia, borate, hydroxide, organic ligands, phosphate, silicate, and sulfide (Stumm and Morgan, 1981, p. 186). Prior to July 1991 , ANC determinations were performed using a Radiometer Autotitration System DTS-833, with a detection limit of $4 \mu \mathrm{eq} / \mathrm{L}$. Since July 1991, Radiometer's Low Ionic Strength Titration System (LIST) has been used to determine the ANC. The calculation procedure determines the ANC, on the basis of the acid-titration data from a modified Gran titration. A modified Gran titration calculation can result in a negative value, and therefore, the method has no detection limit. Negative ANC values have been reported for the data since 1991. 
Table 2. Water-quality laboratory methods and detection limits used to analyze samples collected from Catoctin Mountain, Maryland

[DCP-A, directly coupled plasma atomic emission spectometry, n.a., not applicable; detection limits given in microequivalents per liter, unless indicated otherwise; $\mu \mathrm{mol} / \mathrm{L}$, micromoles per liter]

Solute

Hydrogen ion

(as $\mathrm{pH}$ )

Acid-neutralizing

capacity

Calcium $\left(\mathrm{Ca}^{2+}\right)$

Magnesium $\left(\mathrm{Mg}^{2+}\right)$

Sodium $\left(\mathrm{Na}^{+}\right)$

Potassium $\left(\mathrm{K}^{+}\right)$

Aluminum, total $\left(\mathrm{Al}^{3+}\right)$

Iron, total $\left(\mathrm{Fe}^{2+}\right)$

Silica $\left(\mathrm{SiO}_{2}\right)$

Ammonium $\left(\mathrm{NH}^{4+}\right)$

Chloride $\left(\mathrm{Cl}^{-}\right)$

Nitrite $\left(\mathrm{NO}_{2}{ }^{-}\right)$

Nitrate $\left(\mathrm{NO}_{3}{ }^{-}\right)$

Sulfate $\left(\mathrm{SO}_{4}{ }^{2-}\right)$
Method

Potentiometric

Modified Gran titration

DCP-A

DCP-A

DCP-A

DCP-A

DCP-A

DCP-A

0.38

DCP-A

Ion chromatography

Ion chromatography

Ion chromatography

Ion chromatography

Ion chromatography
0.22

1.8

0.8

0.45

Detection limit

0 (standard units)

n.a.

0.45

0.05

0.13

0.2

$0.43(\mu \mathrm{mol} / \mathrm{L})$

4

0.8 
Laboratory quality assurance and quality control of the analyses were accomplished through a series of approved methods, which included the analysis of standards, duplicates, laboratory blanks, and field blanks. During chemical analysis, known standards were analyzed routinely after every fifth sample, and National Institute of Standards and Technology (NIST) standards were analyzed at the beginning and end of each analysis session. In addition, interlaboratory comparisons of analytical results of standard reference water samples were performed biannually.

Samples collected for stable-isotope analysis were sent to the USGS isotope fractionation laboratory in Reston, Va. The samples were analyzed for hydrogen-isotope activities based on the method of Coplen and others (1991) and for oxygen-isotope activities based on the method of Epstein and Mayeda (1953). The results were reported in per mil $(\%)$ relative to VSMOW (Vienna standard mean ocean water). The hydrogen-isotope method had a $2-\sigma$ precision of $2 \%$ (T.B. Coplen, USGS, written commun., 1990). Hydrogen-isotope results were expressed as delta deuterium $(\delta \mathrm{D})$ relative to VSMOW using the equation

\section{$\delta(\text { Deuterium })_{V S M O W=}$}

$$
\left(\frac{\text { Deuterium Sample }}{\text { Hydrogen }} / \frac{\text { Deuterium VSMOW-1 }}{\text { Hydrogen }}\right)
$$

1,000

The oxygen-isotope method had a $2-\sigma$ precision of $0.2 \%$ (T.B. Coplen, U.S. Geological Survey, written commun., 1990). Oxygen-isotope results were expressed as delta $\mathrm{O}-18\left(\delta^{18} \mathrm{O}\right)$ relative to VSMOW and VPDB (Vienna Peedee belemnite) based on the equation

$$
\delta^{18} O \frac{\text { sample }}{V P D B}=0.97001 \delta^{18} O \underset{\text { sample }}{\text { VSMOW }}-29.99 .
$$

Soil samples were collected from depths ranging from 0.1 to $1.37 \mathrm{~m}$ below land surface during excavation of the lysimeter pits in each watershed. The samples were sent to the Colorado State University Soil Testing Laboratory in Fort Collins, Colorado, for analysis. The samples were analyzed for $\mathrm{pH}$ (1:1 ratio method and saturation paste method), percentage of organic matter (modified Walkley-
Black method), exchangeable $\mathrm{SO}_{4}{ }^{2-}$, cation exchange capacity (CEC), percentage of organic carbon (diffusion-total organic carbon method), percentage of total sulfur (S), aluminum (percentage of total $\mathrm{Al}$ and $1 \mathrm{~N} \mathrm{KCl}$-extractable $\mathrm{Al}$ ), and particle-size analysis. Particulate matter was separated into three size fractions: "sand" (grains that range in size from $2 \mathrm{~mm}$ to $50 \mu \mathrm{m}$ ), "silt" (less than 50 to $2 \mu \mathrm{m}$ ), and "clay" (less than $2 \mu \mathrm{m}$ in size).

\section{DESCRIPTION OF STUDY AREA}

The hydrologic and geochemical characteristics of the two watersheds studied are described in the following paragraphs. The quantity, chemistry, and isotopic compositions of the precipitation, throughfall, soil water, and shallow ground water collected from and near the watersheds are described, as are the physical, chemical, and isotopic characteristics of streamwater. Concentrations of chemical constituents in all of the types of waters sampled are shown by box plots in figure 5 .

\section{Watershed Components}

Watershed components include the forest canopy, the organic-litter layer (forest floor), the mineral soil, the bedrock, and the streambed sediments. Regolith is a general term used to refer to all unconsolidated material above the bedrock, which includes rock fragments, mineral soil, and the organic-litter layer. Incoming precipitation is chemically altered when it interacts with watershed components as it passes through the watershed. As water encounters each type of watershed component, it undergoes different chemical reactions, depending on the composition of the watershed component and the chemistry of the water at the time of contact. The chemical reactions between the water and watershed components take place continuously as the water travels through the watershed to the stream. Therefore, watershed components are important in determining the chemistry of the streamwater. A conceptual diagram of the watershed components and their effect on water chemistry is shown in figure 6. 

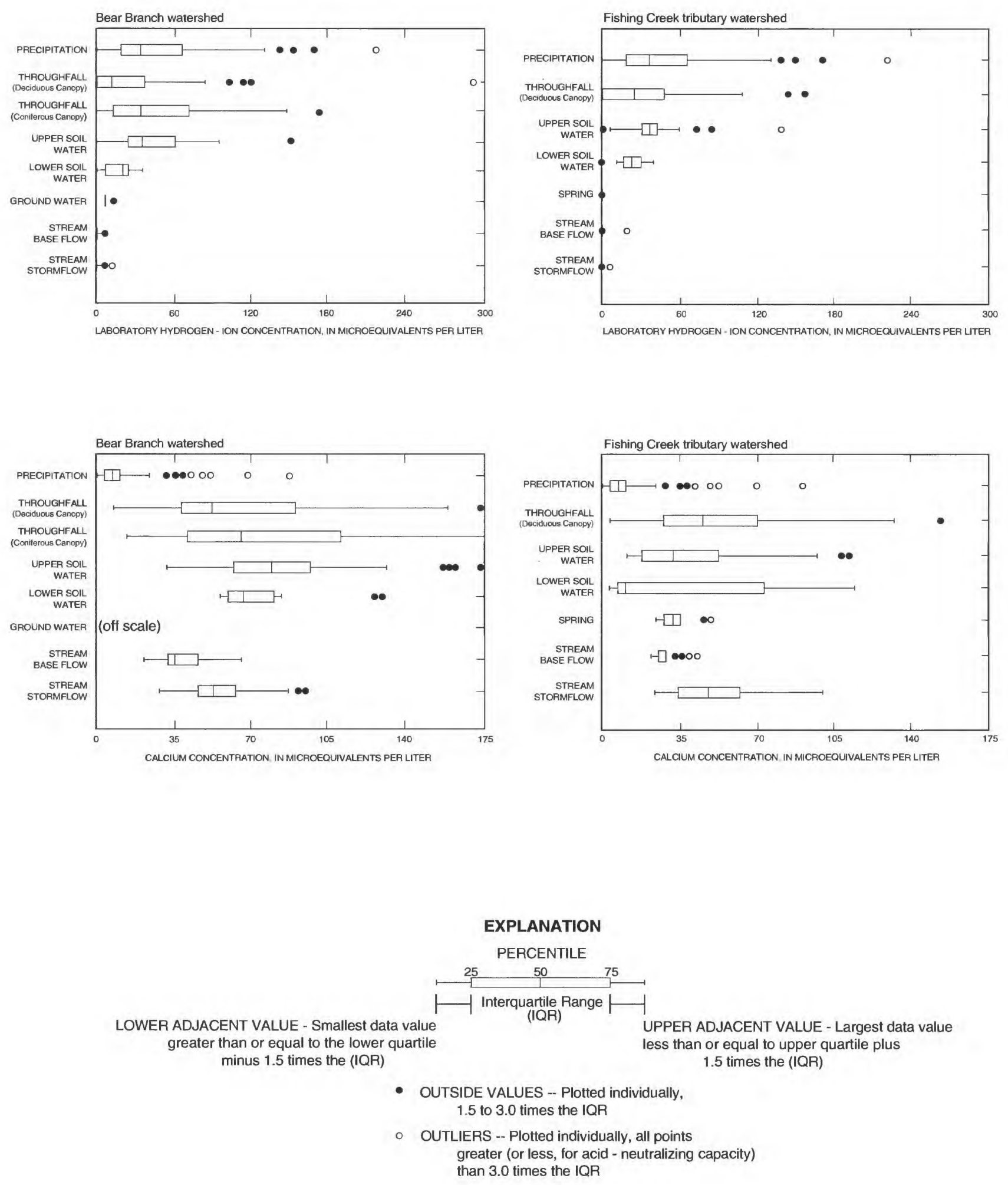

Figure 5. Major inorganic constituent concentrations in all water types collected from the Bear Branch and Fishing Creek tributary watersheds, Catoctin Mountain, Maryland, 1991-93. 

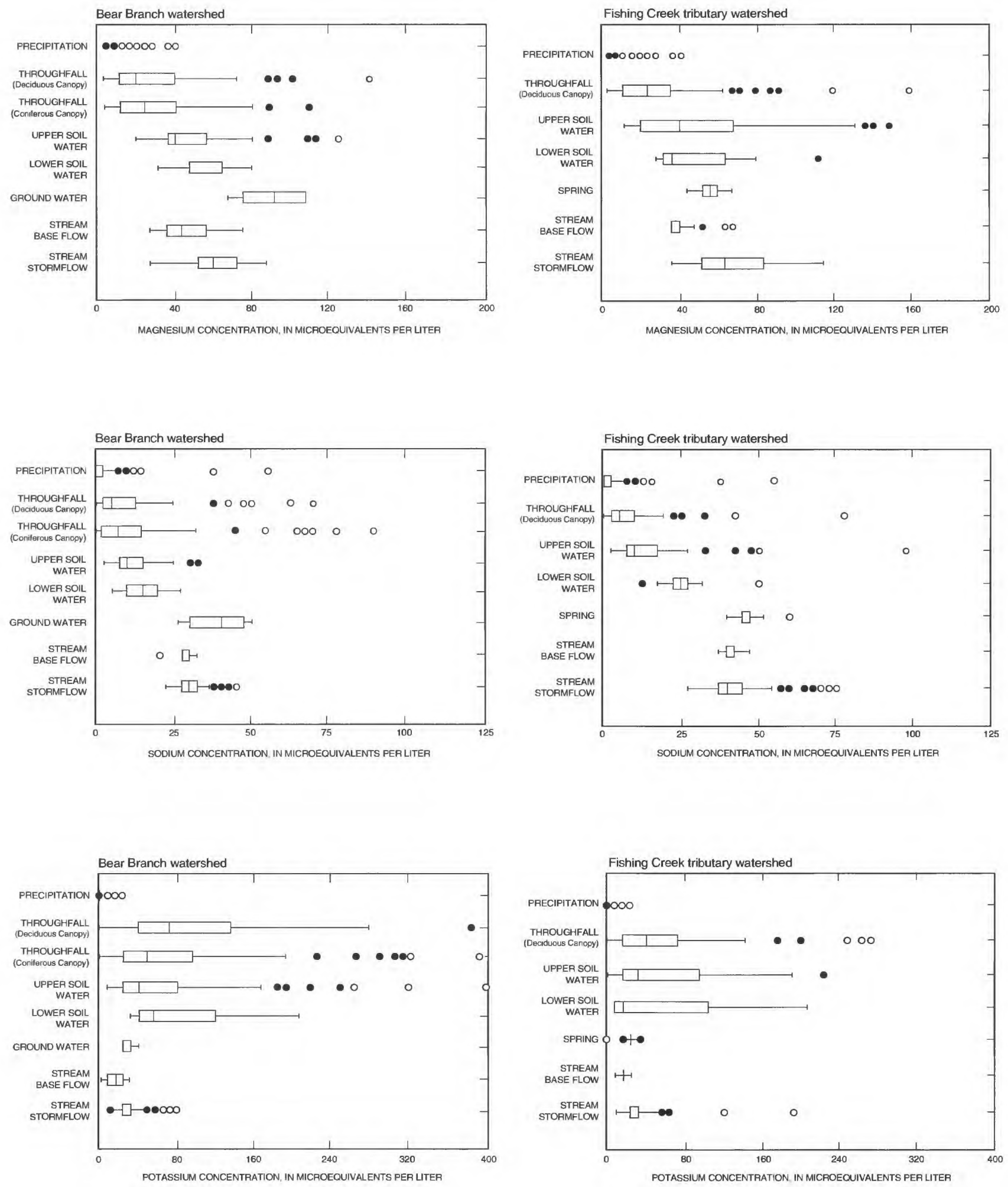

Figure 5. Major inorganic constituent concentrations in all water types collected from the Bear Branch and Fishing Creek tributary watersheds, Catoctin Mountain, Maryland, 1991-93--Continued. 

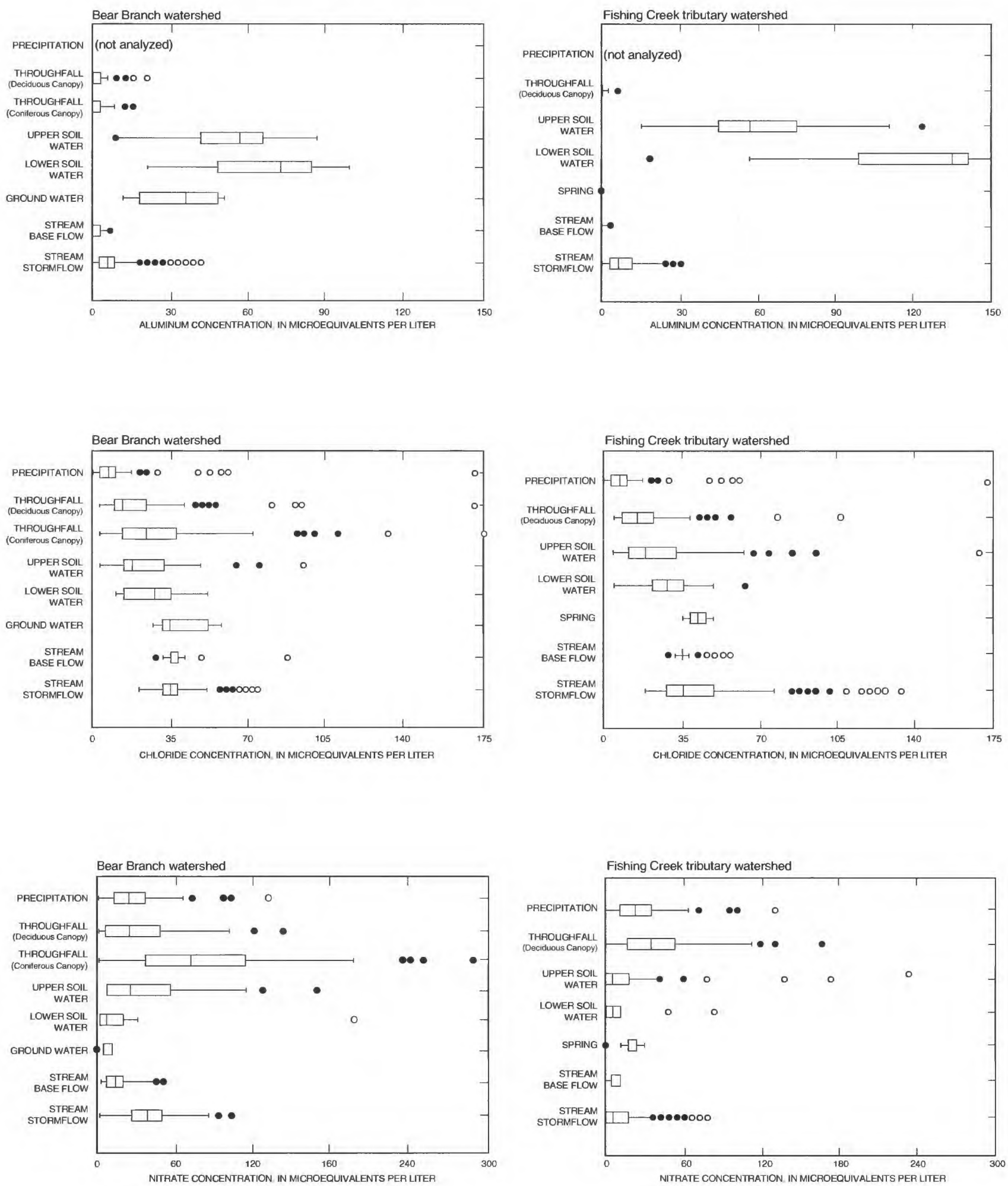

Figure 5. Major inorganic constituent concentrations in all water types collected from the Bear Branch and Fishing Creek tributary watersheds, Catoctin Mountain, Maryland, 1991-93--Continued. 

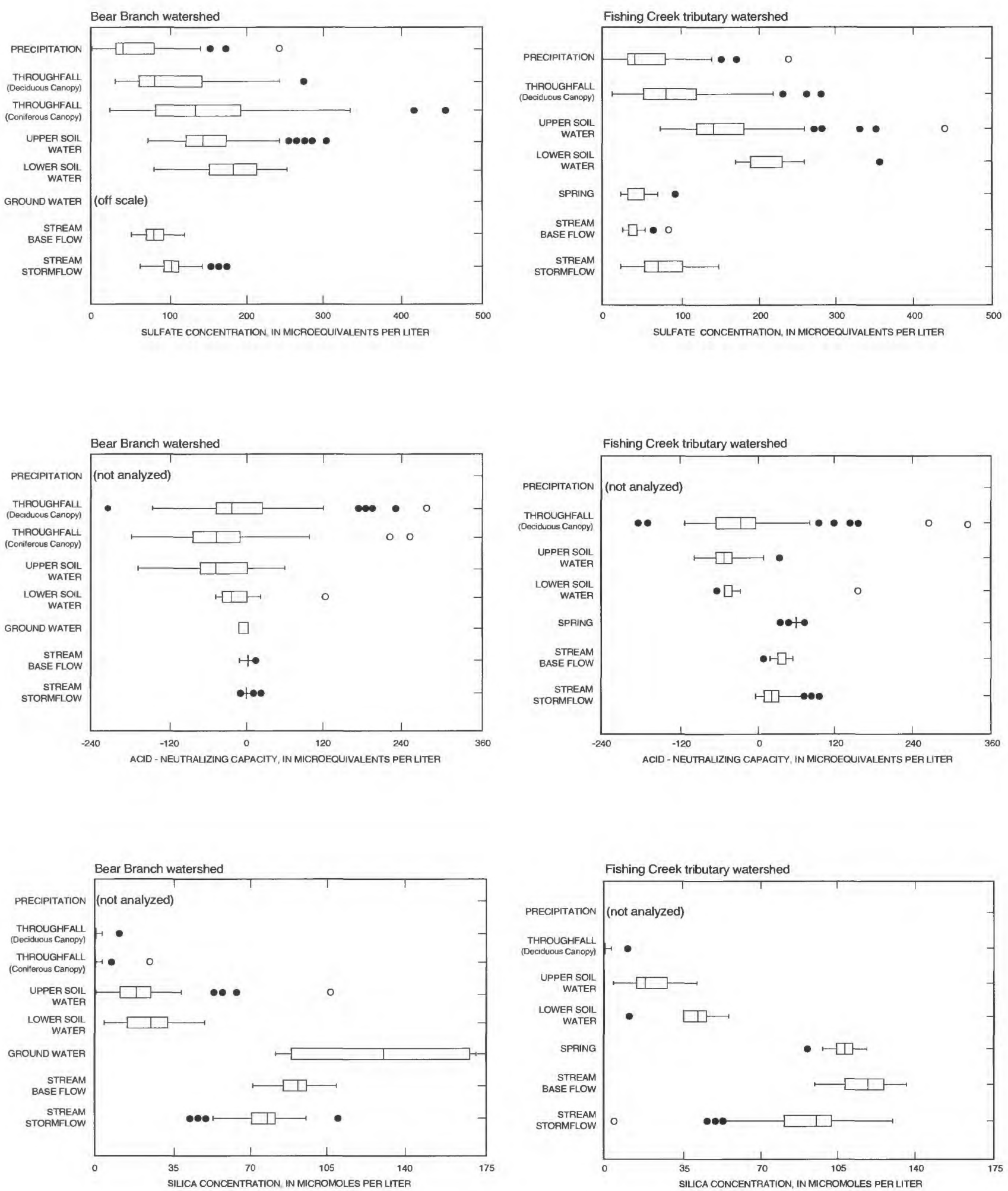

Figure 5. Major inorganic constituent concentrations in all water types collected from the Bear Branch and Fishing Creek tributary watersheds, Catoctin Mountain, Maryland, 1991-93--Continued. 


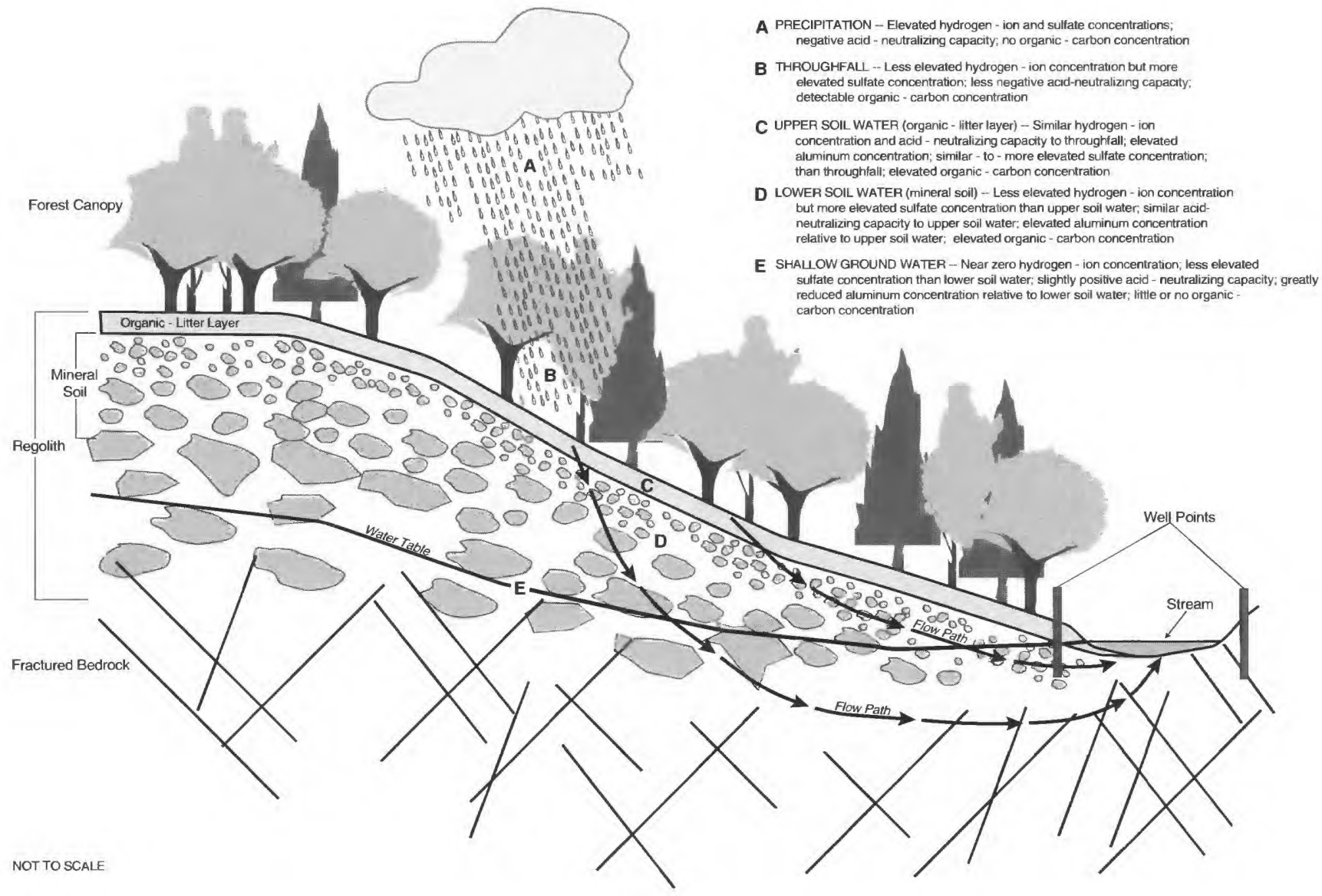

Figure 6. Watershed components and their effect on water chemistry.

Samples from each watershed component, except for forest canopy, were collected from both watersheds and were analyzed for their physical and chemical characteristics. In addition, streambedsediment samples were collected for mineralogic identification. The minerals in streambed sediments can give an indication of the types of minerals in the watershed that are highly resistant to chemical weathering and, thus, are not likely to contribute much to the stream dissolved constituent load.

\section{Forest Canopy}

The forest canopy is the first component that precipitation encounters when it enters a watershed. The forest canopy consists of the vegetative surfaces of trees and plants, which include leaves, twigs, stems, and tree trunks. Lovett and Lindberg (1984) and Puckett (1987), among others, have demonstrated that the forest canopy significantly affects the chemical quality of precipitation.

The forest canopies in the Bear Branch and Fishing Creek tributary watersheds are of varied 
compositions because of the mixed hardwood forests that cover the watersheds. Deciduous species in both watersheds include oak, maple, hickory, beech, wild cherry, and poplar. In addition to the dominantly deciduous species, the Bear Branch watershed includes approximately 10 -percent hemlock trees, and the Fishing Creek tributary watershed includes some mountain laurel shrubs. The effect of the forest canopy in each watershed was measured by collecting throughfall samples from beneath each major canopy type (deciduous and coniferous) and comparing the chemistry to that of precipitation collected for the same time period (usually 1week). The effect of the forest canopy on the chemical quality of the water entering the watersheds is discussed in more detail later in the report.

\section{Organic-Litter Layer}

The organic-litter layer is the first component that water contacts once it reaches the forest floor. The layer consists of organic debris (leaves, roots, twigs, bark, fruits, and stems), which accumulates on the forest floor, as well as rocks and growing and decaying organic matter. The organic-litter layers in the Bear Branch and Fishing Creek tributary watersheds are from 0.10 to $0.15 \mathrm{~m}$ thick.

In general, the organic-litter layer samples from the Bear Branch and Fishing Creek tributary watersheds have an average $\mathrm{pH}$ of 4.16 , an average of about 14-percent organic matter, an average CEC of $20 \mathrm{meq} / 100 \mathrm{~g}$ (milliequivalents per 100 grams), an average of extractable Al of $46 \mathrm{mg} / \mathrm{kg}$ (milligrams per kilogram), and consist of about 50 -percent sand, 41-percent silt, and 9-percent clay. The results of the analyses of the organic-litter layers are summarized in table 3 . The results indicate that the samples from the Bear Branch watershed have slightly more sand and slightly less clay in the organic layer than the samples from the Fishing Creek tributary watershed, and that the samples from both watersheds had similar $\mathrm{pH}$ 's, percentage of organic matter, and percentage of total S. The samples from the Bear Branch watershed had less extractable $\mathrm{SO}_{4}{ }^{2-}$, higher CEC's, higher percentage of organic carbon, slightly less total Al but more extractable Al than the samples from the Fishing Creek tributary watershed. Although little variability is indicated in the results from the two lysimeter pits in the Bear
Branch watershed except in $\mathrm{pH}$ and extractable $\mathrm{Al}$, more variability is indicated between the two lysimeter pits in the Fishing Creek tributary watershed. Pit 1 had higher $\mathrm{pH}$, less organic matter, lower CEC, and lower extractable AI. The difference in the composition of the organic-litter layer from pit 1 to pit 2 may be attributable to the fact that pit 1 is partially shielded by an outcrop of phyllite (fig. 4).

\section{Mineral Soil}

The mineral soil is the next watershed component that water contacts as it travels through a watershed. The mineral soils in these watersheds are residual soils derived from the underlying bedrock. Soils are the product of bedrock that has been acted upon by physical, chemical, and biological processes so that a watershed material is created that can support rooted plants. In general, a vertical soil profile is divided into three horizons: (1) an upper horizon, which has maximum organic accumulation and from which clay minerals, aluminum, and iron have been leached; (2) a middle horizon, which is the zone of accumulation of clay, aluminum, and iron; and (3) a lower horizon, which is the layer of unconsolidated, weathered parent bedrock. The horizons vary in thickness, and not all horizons are present in every soil profile. Most soil profiles contain rock fragments of the parent bedrock, which are scattered throughout each horizon. The rock fragments tend to increase in size with depth, indicating that the upper soil horizons are generally more weathered than the lower horizons.

Mineral soils in the Bear Branch and Fishing Creek tributary watersheds range in thickness from 0 (exposed bedrock) to about $3 \mathrm{~m}$, and soil horizons are poorly developed. The soils are described as very stony loams (Matthews, 1960), and large pieces of rock (less than 1 to more than $1 \mathrm{~m}$ in diameter) were encountered during lysimeter and well-point installation. Analytical results for the soil samples collected during lysimeter pit excavation are summarized in table 4.

The results from the soil analyses indicate that the percentage of sand in the lysimeter pits increases with depth below land surface, whereas the percentages of silt and clay decrease (table 4, fig. 7). In general, the $\mathrm{pH}$ of the soils increases 
[ $1: 1 \mathrm{pH}$, ratio method of $\mathrm{pH}$ determinations; Paste $\mathrm{pH}$, saturation paste method of $\mathrm{pH}$ determination; meq $/ 100 \mathrm{~g}$, milliequivalents per 100 grams; $1 \mathrm{~N} \mathrm{KCl}$, one normal potassium chloride solution; $\mathrm{mg} / \mathrm{kg}$, milligrams per kilogram]

\begin{tabular}{|c|c|c|c|c|c|c|c|c|c|c|c|c|}
\hline \multirow[b]{2}{*}{ Location } & \multicolumn{3}{|c|}{ Particle-size analysis, in percent } & \multirow{2}{*}{$\begin{array}{l}1: 1 \\
\mathrm{pH}\end{array}$} & \multirow{2}{*}{$\begin{array}{c}\text { Paste } \\
\mathrm{pH}\end{array}$} & \multirow{2}{*}{$\begin{array}{l}\text { Percent } \\
\text { organic } \\
\text { matter }\end{array}$} & \multirow{2}{*}{$\begin{array}{l}\text { Extractable } \\
\text { sulfate } \\
(\mathrm{meq} / 100 \mathrm{~g})\end{array}$} & \multirow{2}{*}{$\begin{array}{c}\text { Cation } \\
\text { exchange } \\
\text { capacity } \\
\text { (meq/100 g) }\end{array}$} & \multirow{2}{*}{$\begin{array}{l}\text { Carbon, } \\
\text { organic } \\
\text { (percent) }\end{array}$} & \multirow{2}{*}{$\begin{array}{c}\text { Sulfur, } \\
\text { total } \\
\text { (percent) }\end{array}$} & \multirow{2}{*}{$\begin{array}{l}\text { Aluminum, } \\
\text { total } \\
\text { (percent) }\end{array}$} & \multirow{2}{*}{$\begin{array}{c}1 \mathrm{~N} \mathrm{KCl} \\
\text { Extractable } \\
\text { Aluminum } \\
(\mathrm{mg} / \mathrm{kg})\end{array}$} \\
\hline & Sand & Silt & Clay & & & & & & & & & \\
\hline
\end{tabular}

\section{Bear Branch watershed}

\begin{tabular}{|c|c|c|c|c|c|c|c|c|c|c|c|c|}
\hline Lysimeter pit 1 & 49.9 & 42.8 & 7.3 & 4.3 & 4.4 & 15.4 & 34.3 & 31.8 & 6.3 & 0.06 & 3.75 & 53.4 \\
\hline Lysimeter pit 2 & 57.3 & 37.2 & 5.5 & 3.8 & 3.8 & 17.1 & 34.3 & 38.8 & 9.2 & 0.05 & 3.28 & 64.9 \\
\hline
\end{tabular}

\section{Fishing Creek tributary watershed}

\begin{tabular}{|c|c|c|c|c|c|c|c|c|c|c|c|c|}
\hline Lysimeter pit 1 & 46.7 & 42.4 & 10.9 & 4.7 & 4.6 & 5.6 & 54.1 & 15.8 & 2.0 & 0.03 & 4.75 & 25.5 \\
\hline Lysimeter pit 2 & 44.5 & 42.8 & 12.6 & 4.3 & 4.3 & 16.2 & 46.8 & 23.2 & 5.7 & 0.04 & 4.95 & 42.3 \\
\hline
\end{tabular}


Table 4. Results of mineral soil analyses of samples collected from Catoctin Mountain, Maryland

[ 1:1 $\mathrm{pH}$, ratio method of $\mathrm{pH}$ determination; Paste $\mathrm{pH}$, saturation paste method of $\mathrm{pH}$ determination; meq/100g, milliequivalents per 100 grams;

$1 \mathrm{~N} \mathrm{KCl}$, one normal potassium chloride solution; $\mathrm{mg} / \mathrm{kg}$, milligrams per kilogram]

\begin{tabular}{|c|c|c|c|c|c|c|c|c|c|c|c|c|}
\hline \multirow[b]{2}{*}{ Location } & \multicolumn{3}{|c|}{ Particle-size analysis, in percent } & \multirow{2}{*}{$\begin{array}{l}1: 1 \\
\mathrm{pH}\end{array}$} & \multirow{2}{*}{$\begin{array}{c}\text { Paste } \\
\mathrm{pH}\end{array}$} & \multirow{2}{*}{$\begin{array}{l}\text { Percent } \\
\text { organic } \\
\text { matter }\end{array}$} & \multirow{2}{*}{$\begin{array}{c}\text { Extractable } \\
\text { sulfate } \\
\text { (meq } / 100 \mathrm{~g})\end{array}$} & \multirow{2}{*}{$\begin{array}{l}\text { Cation } \\
\text { exchange } \\
\text { capacity } \\
(\mathrm{meq} / 100 \mathrm{~g})\end{array}$} & \multirow{2}{*}{$\begin{array}{l}\text { Carbon, } \\
\text { organic } \\
\text { (percent) }\end{array}$} & \multirow{2}{*}{$\begin{array}{l}\text { Sulfur, } \\
\text { total } \\
\text { (percent) }\end{array}$} & \multirow{2}{*}{$\begin{array}{c}\text { Aluminum, } \\
\text { total } \\
\text { (percent) }\end{array}$} & \multirow{2}{*}{$\begin{array}{c}1 \mathrm{~N} \mathrm{KCl} \\
\text { Extractable } \\
\text { Aluminum } \\
(\mathrm{mg} / \mathrm{kg})\end{array}$} \\
\hline & Sand & Silt & Clay & & & & & & & & & \\
\hline
\end{tabular}

\section{Bear Branch watershed}

Depth in lysimeter pit 1

\begin{tabular}{|c|c|c|c|c|c|c|c|c|c|c|c|c|}
\hline 0.56 meter & 40.2 & 42.9 & 16.8 & 4.8 & 4.8 & 1.0 & 19.1 & 10.6 & 0.4 & 0.01 & 4.64 & 36.3 \\
\hline \multicolumn{13}{|c|}{ Depth in lysimeter pit 2} \\
\hline 0.20 meter & 44.0 & 44.8 & 11.2 & 4.5 & 4.6 & 3.7 & 11.4 & 21.2 & 1.6 & 0.01 & 3.82 & 57.4 \\
\hline 0.51 meter & 61.5 & 29.8 & 8.7 & 4.8 & 4.8 & 1.1 & 18.3 & 7.1 & 0.4 & 0.01 & 3.15 & 15.9 \\
\hline
\end{tabular}

Fishing Creek tributary watershed

Depth in lysimeter pit 1

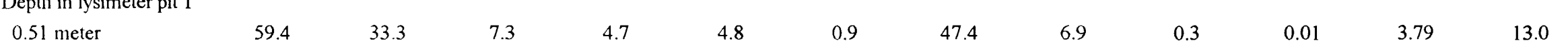

Depth in lysimeter pit 2

\begin{tabular}{|c|c|c|c|c|c|c|c|c|c|c|c|c|}
\hline 0.20 meter & 32.8 & 48.2 & 19 & 4.8 & 4.8 & 4.5 & 47.4 & 14.3 & 1.6 & 0.02 & 5.26 & 41.6 \\
\hline 0.61 meter & 41.9 & 42.0 & 16 & 4.7 & 4.8 & 1.2 & 36.4 & 10.5 & 0.4 & 0.03 & 5.26 & 34.4 \\
\hline 0.91 meter & 66.2 & 27.1 & 6.9 & 4.9 & 5.1 & 0.6 & 23.9 & 7.1 & 0.1 & 0.01 & 4.73 & 23.8 \\
\hline 1.37 meter & 67.7 & 26.5 & 5.8 & 5.0 & 5.1 & 0.7 & 22.5 & 7.0 & 0.2 & 0.02 & 4.49 & 23.0 \\
\hline
\end{tabular}




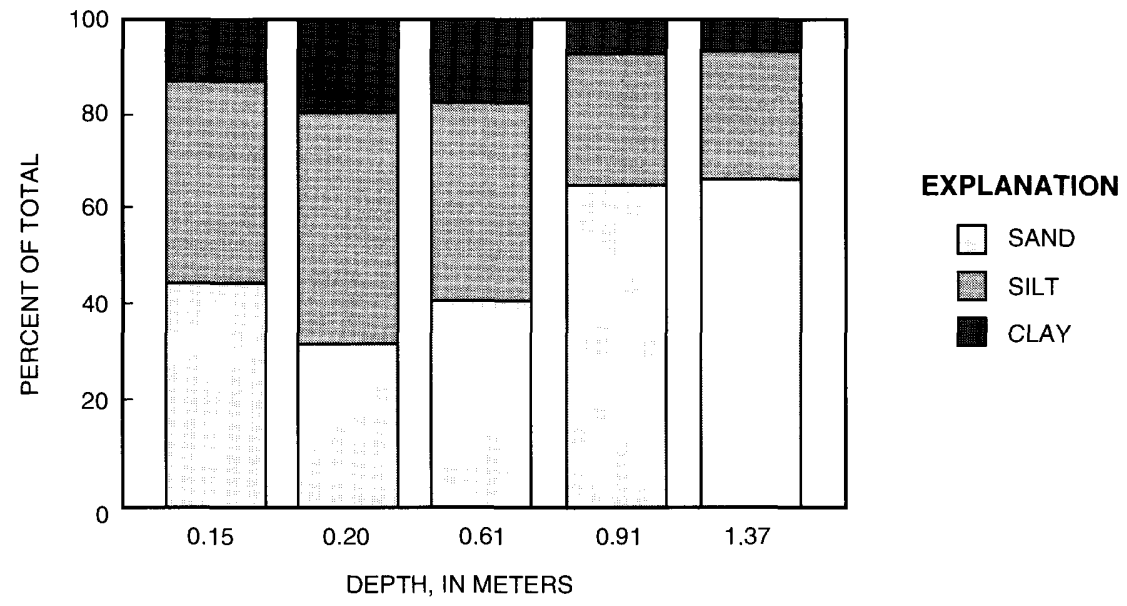

Figure 7. Grain-size fractions of soils from Fishing Creek tributary lysimeter pit 2, Catoctin Mountain, Maryland.

slightly with depth because of an increasing content of less-weathered parent material. The percentage of organic matter, percentage of organic carbon, percentage of total $\mathrm{Al}$, and exchangeable $\mathrm{SO}_{4}{ }^{2-}$, $\mathrm{CEC}$, and extractable $\mathrm{Al}$ all decrease with depth (table 4). At a depth of 0.51 to $0.61 \mathrm{~m}$ below land surface, the soils from all four lysimeter pits had an average $\mathrm{pH}$ of $4.75,1.1$-percent organic matter, 8.8 meq/100 g CEC, 0.4-percent organic carbon, 0.01percent total S, 4.2-percent total $\mathrm{Al}$, and $25 \mathrm{mg} / \mathrm{kg}$ extractable Al. The largest difference between soil samples from the Bear Branch and Fishing Creek tributary watersheds was in exchangeable $\mathrm{SO}_{4}{ }^{2-}$; the Bear Branch watershed had an average of 18.7 meq/100 g, whereas Fishing Creek tributary watershed had an average of $41.6 \mathrm{meq} / 100 \mathrm{~g}$ at depths ranging from 0.51 to $0.61 \mathrm{~m}$ below land surface.

Soil samples collected from specific depths from one soil pit in each watershed were analyzed by X-ray diffraction at the USGS mineral-water interaction laboratory in Reston, Va., to identify the dominant types of minerals present in the soils. The location of the soil pits where these samples were obtained is shown for the Bear Branch and Fishing Creek tributary watersheds on figures 3 and 4, respectively. In the Bear Branch watershed, soil samples were collected at depths of $0.10,0.15,0.33$, and $0.46 \mathrm{~m}$ below land surface. In the Fishing Creek tributary watershed, soil samples were collected at depths of $0.05,0.20,0.33$, and $0.51 \mathrm{~m}$ below land surface. The samples were first analyzed in bulk scans; that is, a subset of the soil sample as it was collected from the field was X-rayed. The results of the bulk scans indicated that the amount of plagioclase feldspar increases with depth below land surface in both watersheds. The samples then were sieved to obtain a less than $1-\mu \mathrm{m}$ fraction and analyzed by $\mathrm{X}$-ray diffraction to identify the dominant clay minerals. In both watersheds, the dominant clay mineral is hydroxy-interlayer vermiculite, whereas kaolinite and smaller amounts of gibbsite also are present (D.L. Webster, U.S. Geological Survey, written commun., 1994). 


\section{Bedrock}

Bedrock underlies the soils in a watershed and gives residual soils their original physical and chemical characteristics. As water travels through a watershed, it eventually reaches the ground-water table, which may be located in the soil zone or deeper in the bedrock. If the bedrock has primary porosity, the ground water is present in the interstitial spaces between mineral grains. If the bedrock has no primary porosity but is fractured, it is said to have secondary porosity. In this case, the ground water is present in the fractures in the bedrock.

The bedrock underlying both watersheds is the Weverton Formation of late Precambrian or Cambrian age. The Bear Branch watershed is underlain by the lower member of the Weverton Formation. The lower member is characterized by quartzose graywacke and graywacke conglomerate interbedded with dark-colored phyllites (Fauth, 1977). Fishing Creek tributary watershed is underlain by the upper member of the Weverton Formation. The upper member is characterized by interbedded protoquartzite, graywacke, and quartzite, interbedded with phyllite and quartz phyllite and overlain by ferruginous quartzite and conglomerate (Fauth, 1977). An outcrop of a phyllite, which is either the upper part of the Weverton or the lower part of the Harpers Formation, is present near the streamflowgaging station on Fishing Creek tributary (fig.4).

The Weverton Formation has little primary porosity because its individual grains are cemented with silica, which is partially the result of metamorphism. The Weverton Formation is well fractured, however, as a result of a long geologic history of tectonic processes. Therefore, ground water in the two watersheds flows through fractures in the bedrock and through the saturated, coarse regolith overlying the bedrock.

Samples of bedrock and float (isolated, displaced fragments of rock) from each of the watersheds were collected and submitted to the USGS geochemistry laboratory in Denver, Colo., for whole-rock analyses. Samples were analyzed for 10 major oxides by $\mathrm{X}$-ray fluorescence and for loss on ignition. Samples were analyzed for $\mathrm{CO}_{2}$ by ex- traction through coulometric titration and for $\mathrm{FeO}$ by potentiometric titration.

The four quartzite samples from the Bear Branch watershed submitted for whole-rock analyses ranged from 75- to 90 -percent $\mathrm{SiO}_{2}$, with the remainder of the rock composed of $\mathrm{Al}_{2} \mathrm{O}_{3}, \mathrm{Fe}_{\mathrm{T}} \mathrm{O}_{3}$ and $\mathrm{K}_{2} \mathrm{O}$. The four quartzite samples submitted from the Fishing Creek tributary watershed contained more $\mathrm{SiO}_{2}$, with the percentage ranging from 95 to 97. One sample of massive quartz (vein quartz) was submitted, which was almost pure $\mathrm{SiO}_{2}$. A sample of the phyllite, which crops out near the streamflow-gaging station on Fishing Creek tributary contained much less $\mathrm{SiO}_{2}$ than the quartzite samples submitted, with the balance of the rock consisting of $\mathrm{Al}_{2} \mathrm{O}_{3}, \mathrm{FeO}, \mathrm{Fe}_{\mathrm{T}} \mathrm{O}_{3}, \mathrm{MgO}$, and $\mathrm{K}_{2} \mathrm{O}$. The results of the whole-rock analyses are presented in tables $5 \mathrm{~A}$ and $\mathrm{B}$.

Thin sections were made from samples of bedrock and float collected from each of the watersheds. These rock samples were the same samples that were submitted for whole-rock analyses. For comparison, samples were collected from a Weverton Formation outcrop exposed by a fresh railroad cut in Thoroughfare Gap near The Plains in northern Virginia. The thin sections were subjected to petrographic analysis, cathodoluminescence, and scanning electron microscopy for determination of mineralogy. The results of the petrographic analyses are summarized in table 6.

Cathodoluminescence techniques were used specifically to examine for carbonate minerals in the thin sections. Qualitative examination by cathodoluminescence indicated no carbonate minerals but confirmed the presence of potassic feldspar. The feldspar is present as isolated grains and, at places, in thin horizons along bedding planes. The presence of potassic feldspar also was confirmed by scanning electron microscopy (SEM). SEM with qualitative energy dispersive $\mathrm{X}$-ray analysis was used to identify minerals present in the Weverton Formation and to obtain qualitative chemical compositions. In addition to the major mineral component, quartz, small amounts of epidote, ilmenite, rutile, sericite, tourmaline, and zircon were observed. Most of these minerals were 
Table 5a. Results of whole-rock analyses for Bear Branch watershed, Catoctin Mountain, Maryland

[ Values in percent; <, less than]

\section{Sample type}

\begin{tabular}{|c|c|c|c|c|}
\hline Constituent & Quartzite & Quartzite & Quartzite & Quartzite \\
\hline Silicon dioxide $\left(\mathrm{SiO}_{2}\right)$ & 87.2 & 87.1 & 74.6 & 90.1 \\
\hline Alumium oxide $\left(\mathrm{Al}_{2} \mathrm{O}_{3}\right)$ & 5.65 & 4.92 & 11.4 & 4.1 \\
\hline Ferrous oxide $(\mathrm{FeO})$ & 0.48 & 0.6 & 0.89 & 0.36 \\
\hline $\begin{array}{l}\text { Total iron, expressed as } \\
\text { ferric oxide }\left(\mathrm{Fe}_{\mathrm{T}} \mathrm{O}_{3}\right)\end{array}$ & 1.72 & 2.43 & 3.55 & 1.11 \\
\hline Magnesium oxide $(\mathrm{MgO})$ & 0.74 & 0.82 & 1.28 & 0.61 \\
\hline Calcium oxide $(\mathrm{CaO})$ & $<0.02$ & $<0.02$ & $<0.02$ & $<0.02$ \\
\hline Sodium oxide $\left(\mathrm{Na}_{2} \mathrm{O}\right)$ & $<0.15$ & $<0.15$ & $<0.15$ & $<0.15$ \\
\hline Potassium oxide $\left(\mathrm{K}_{2} \mathrm{O}\right)$ & 2.57 & 2.22 & 5.12 & 1.84 \\
\hline Titanium oxide $\left(\mathrm{TiO}_{2}\right)$ & 0.23 & 0.51 & 0.88 & 0.22 \\
\hline Phosphorous oxide $\left(\mathrm{P}_{2} \mathrm{O}_{5}\right)$ & $<0.05$ & $<0.05$ & $<0.05$ & $<0.05$ \\
\hline Manganese oxide $(\mathrm{MnO})$ & $<0.02$ & $<0.02$ & $<0.02$ & $<0.02$ \\
\hline Carbon dioxide $\left(\mathrm{CO}_{2}\right)$ & $<0.01$ & $<0.01$ & $<0.01$ & $<0.01$ \\
\hline Loss on ignition (LOI) & 1.16 & 1.06 & 1.99 & 1.03 \\
\hline
\end{tabular}

Table 5b. Results of whole-rock analyses for Fishing Creek tributary watershed, Catoctin Mountain, Maryland

[Values in percent; <, less than]

Sample type

\begin{tabular}{|c|c|c|c|c|c|c|}
\hline Constituent & Phyllite & Quartzite & Quartzite & $\begin{array}{r}\text { Massive } \\
\text { quartz }\end{array}$ & Quartzite & Quartzite \\
\hline Silicon dioxide $\left(\mathrm{SiO}_{2}\right)$ & 64.9 & 95.2 & 97.3 & 98.5 & 96.1 & 96.3 \\
\hline Alumium oxide $\mathrm{Al}_{2} \mathrm{O}_{3}$ & 18.1 & 1.58 & 0.94 & 0.29 & 1.06 & 1.06 \\
\hline Ferrous oxide $(\mathrm{FeO})$ & 3.61 & 0.23 & 0.07 & 0.02 & 0.21 & 0.06 \\
\hline $\begin{array}{l}\text { Total iron, expressed as } \\
\text { ferric oxide }\left(\mathrm{Fe}_{\mathrm{T}} \mathrm{O}_{3}\right)\end{array}$ & 5.61 & 0.59 & 0.16 & $<0.04$ & 0.72 & 0.28 \\
\hline Magnesium oxide $(\mathrm{MgO})$ & 1.47 & 0.27 & $<0.10$ & $<0.10$ & 0.2 & 0.17 \\
\hline Calcium oxide $(\mathrm{CaO})$ & 0.09 & $<0.02$ & $<0.02$ & $<0.02$ & $<0.02$ & $<0.02$ \\
\hline Sodium oxide $\left(\mathrm{Na}_{2} \mathrm{O}\right)$ & 0.92 & $<0.15$ & $<0.15$ & $<0.15$ & $<0.15$ & $<0.15$ \\
\hline Potassium oxide $\left(\mathrm{K}_{2} \mathrm{O}\right)$ & 4.11 & 0.54 & 0.4 & $<0.02$ & 0.32 & 0.32 \\
\hline Titanium oxide $\left(\mathrm{TiO}_{2}\right)$ & 0.91 & 0.18 & 0.24 & $<0.02$ & 0.17 & 0.36 \\
\hline Phosphorous oxide $\left(\mathrm{P}_{2} \mathrm{O}_{5}\right)$ & 0.13 & 0.06 & $<0.05$ & $<0.05$ & $<0.05$ & $<0.05$ \\
\hline Manganese oxide $(\mathrm{MnO})$ & 0.03 & $<0.02$ & $<0.02$ & $<0.02$ & $<0.02$ & $<0.02$ \\
\hline Carbon dioxide $\left(\mathrm{CO}_{2}\right)$ & $<0.01$ & $<0.01$ & $<0.01$ & $<0.01$ & $<0.01$ & $<0.01$ \\
\hline Loss on ignition (LOI) & 3.26 & 0.44 & 0.15 & 0.02 & 0.33 & 0.3 \\
\hline
\end{tabular}


Table 6. Results of thin-section analyses of samples collected from Catoctin Mountain, Maryland

[BB, Bear Branch watershed; FCT, Fishing Creek tributary watershed; all values given in percent; --, none detected; tr, trace]

\begin{tabular}{lccccccc}
\hline $\begin{array}{l}\text { Thin-section } \\
\text { identification } \\
\text { number }\end{array}$ & Quartz & Mica/illite & $\begin{array}{l}\text { Altered mica } \\
\text { (chlorite or } \\
\text { biotite or } \\
\text { vermiculite) }\end{array}$ & $\begin{array}{l}\text { Fresh } \\
\text { biotite }\end{array}$ & Orthoclase & $\begin{array}{l}\text { Zircon, } \\
\text { rutile, ilmenite }\end{array}$ & Opaques \\
\hline BB2 & 58 & - & 35 & 5 & 2 & - & - \\
BB3 & 43 & - & 55 & - & - & - & 2 \\
FCT2 & 78 & 15 & - & - & 7 & tr & - \\
FCT5 & 86 & 10 & - & - & 4 & tr & -- \\
\hline
\end{tabular}

present only in trace amounts and were not abundant enough to be detected in the petrographic point counts.

\section{Streambed Sediments}

Streambed sediment can give an indication of the character of the watershed components that water has passed through on its way to the stream. Usually, in high-gradient streams such as those in this study, fine-grained materials, such as soil particles, are carried from the streambed by streamflow. However, coarser-grained materials, such as rock fragments, are heavier and settle on the streambed.

Three streambed-sediment samples from each watershed were collected near and just upstream of the streamflow-gaging stations and sent to a USGS laboratory in Reston, Va., for analysis. The sediment samples were sieved, and the sediment that passed the 80-mesh screen but was retained on the 200-mesh screen was the part of the sample that was analyzed. The sieved sample then was split into two fractions: that with specific gravity greater than 2.80 (the heavy-mineral suite) and that with specific gravity less than 2.80 (the light-mineral suite). For samples with specific gravity greater than 2.80 , the sample was divided again into opaque minerals and non-opaque minerals. The types of minerals in all samples were identified by visual ob- servation with a binocular microscope and by measuring the indices of refraction with immersion oils. The results of the analyses of the streambed sediments are presented in table 7.

In the heavy-mineral suite of the samples from both watersheds, the opaque minerals identified were brown ilmenite, ilmenite, and leucoxene (altered ilmenite) (James Owens, U.S. Geological Survey, written commun., 1992). The brown ilmenite consisted mostly of iron oxides, the ilmenite was present as unusual small cubic crystals, and the leucoxene was present as acicular crystals or as light brown masses (James Owens, U.S. Geological Survey, written commun., 1992). Neither apatite nor magnetite were present in any of the samples. The non-opaque minerals identified were epidote, rutile, tourmaline, and zircon. In general, slightly more tourmaline and slightly less zircon were present in the samples from Fishing Creek tributary than from Bear Branch. The epidote was present in green crystalline form. The rutile was present as paleyellow-colored grains. The tourmaline was present as crystals with very little rounding. The zircon was mostly subrounded and present less commonly as metamict and more commonly as non metamict. 
Table 7. Results of streambed-sediment analyses of samples collected from Catoctin Mountain, Maryland

$[-$, none detected; $>$, greater than; $<$, less than $]$

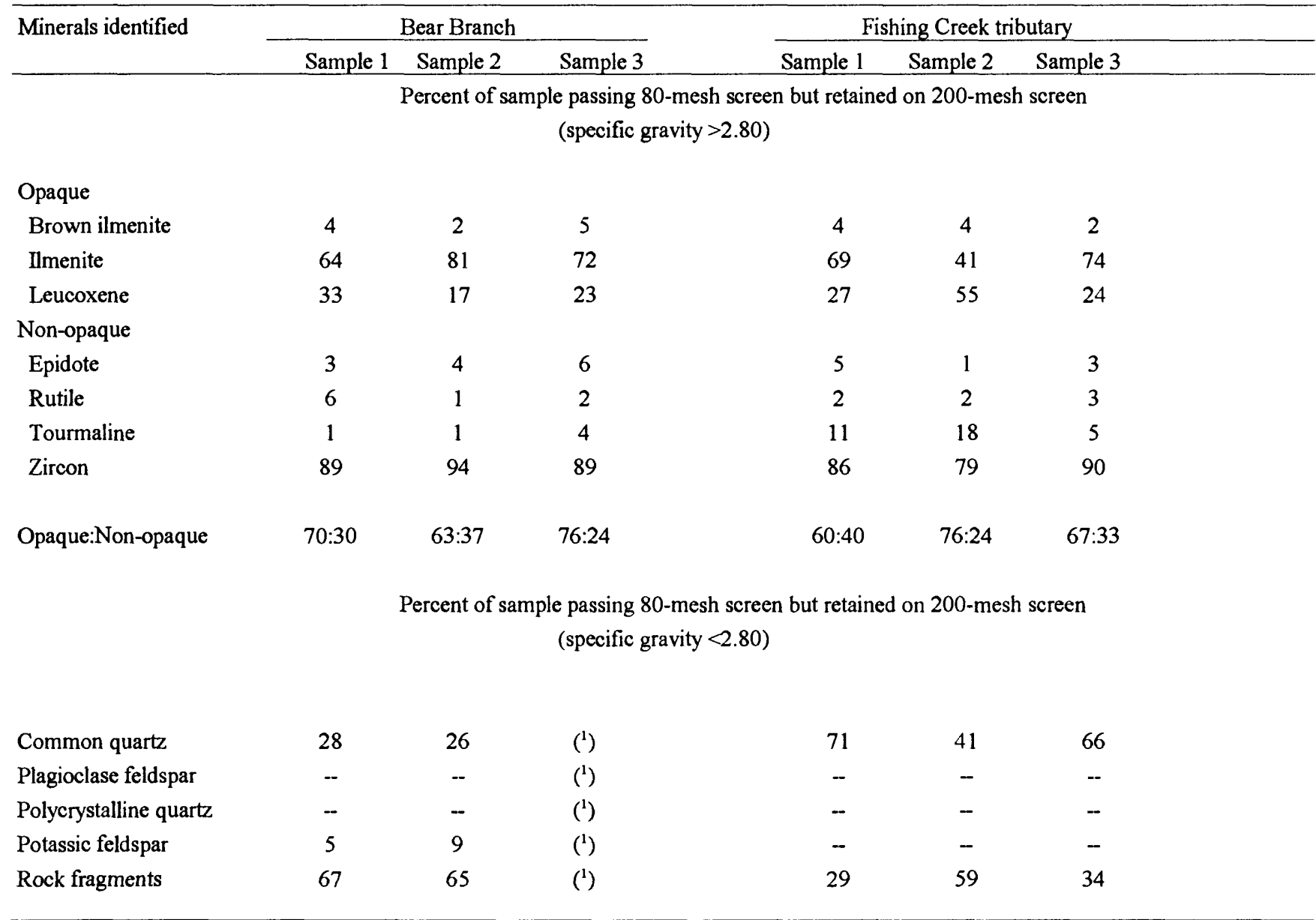

${ }^{1}$ Sample not collected

Of the light-mineral suite of the samples from both watersheds, the identified minerals were common quartz, potassic feldspar, and rock fragments. Neither polycrystalline quartz nor plagioclase feldspar were identified in any of the samples. The rock fragments were mostly a quartz-muscovite assemblage, with the muscovite content of the Bear Branch samples significantly higher than the Fishing Creek tributary samples (James Owens, U.S. Geological Survey, written commun., 1992). The Bear Branch samples also had more, though still minor amounts of, potassic feldspar than the Fishing Creek tributary samples (James Owens, U.S. Geological Survey, written commun., 1992).

\section{Precipitation}

Precipitation is the ultimate source of recharge to ground water in the small headwater watersheds studied. Therefore, the quantity and quality of the precipitation entering a watershed have significant effects on the hydrologic and geochemical responses of the streams. This section of the report describes the long-term (1982-93) quantity and quality of precipitation on Catoctin Mountain, as well as information specific to the period of study (1990-93). Detailed precipitation quantity and chemistry data collected from the USGS Catoctin Mountain precipitation-collection station for 
1982-91 are given in Rice and others (1993), and for 1987-93 in Rice and others (1996, in press).

From 1982 through 1993, the average annual amount of precipitation on Catoctin Mountain was $1,145 \mathrm{~mm}$. This 12-year average compares favorably with the long-term average (1931-80) for north-central Maryland, which was $1,110 \mathrm{~mm}(\mathrm{Na}-$ tional Oceanic and Atmospheric Administration, 1981). For the 12-year period of record on Catoctin Mountain, the variability in the annual amount of precipitation ranged from a minimum of $937 \mathrm{~mm}$ in 1982 to a maximum of $1,485 \mathrm{~mm}$ in 1984 (table 8 ). For the period of this study, 1990-93, the annual amounts of precipitation ranged from a minimum of $964 \mathrm{~mm}$ in 1991 to a maximum of $1,243 \mathrm{~mm}$ in 1990 , values that bracket the long-term average amount of precipitation for the region.

Precipitation falling on Catoctin Mountain is some of the most acidic in the United States (Rice and Bricker, 1992b). The relations among $\mathrm{SO}_{4}{ }^{2-}$ and $\mathrm{NO}_{3}{ }^{-}$concentrations and $\mathrm{pH}$ in precipitation are shown graphically in figure 8 . Annual volumeweighted concentrations of chemical constituents for the 12-year period of record of precipitation (1982-93) are shown in table 9. For the 12-year period of record, the volume-weighted average fieldmeasured $\mathrm{pH}$ was 4.16 , and the volume-weighted average concentrations of $\mathrm{SO}_{4}{ }^{2-}$ and $\mathrm{NO}_{3}{ }^{-}$were 51.3 and $23.6 \mu \mathrm{eq} / \mathrm{L}$, respectively (table 9). Examination of the volume-weighted average concentrations in table 9 reveals the annual variability of precipitation constituents. No seasonal pattern in variability has been observed in base-cation concentrations; however, $\mathrm{H}^{+}$ion, $\mathrm{SO}_{4}{ }^{2-}$ and $\mathrm{NO}_{3}{ }^{-}$concentrations do show a seasonal pattern, with the higher concentrations during the summer months. Precipitation chemistry data are shown on box plots for 1990-93 (fig. 5). The plots indicate that the $\mathrm{H}^{+}$ion and $\mathrm{SO}_{4}{ }^{2-}$ have the greatest variability for the period.

Atmospheric wet-deposition loadings were calculated for each year for the period of record from the USGS Catoctin Mountain precipitationcollection station (1982-93). The wet-precipitation loadings, in moles per hectare per year, are shown in table 10 .
Table 8. Annual amount of precipitation recorded on Catoctin Mountain, Maryland, 1982-93

[Data from Rice and others $(1993,1996)]$

\begin{tabular}{|c|c|}
\hline Year & $\begin{array}{c}\text { Annual precipitation } \\
\text { (millimeters) }\end{array}$ \\
\hline 1982 & 937 \\
\hline 1983 & 1,468 \\
\hline 1984 & 1,485 \\
\hline 1985 & 1,119 \\
\hline 1986 & 944 \\
\hline 1987 & 1,095 \\
\hline 1988 & 951 \\
\hline 1989 & 1,082 \\
\hline 1990 & 1,243 \\
\hline 1991 & 964 \\
\hline 1992 & 1,232 \\
\hline 1993 & 1,217 \\
\hline Annua & rd is 1,145 millimeters \\
\hline
\end{tabular}

Freshwater (streams, lakes, ground water) originates entirely from precipitation. Hydrogen and oxygen combine to form the water molecule, and their isotopic fractionations are usually covariant. Thus, the spatial and temporal variations in isotopic composition of precipitation can be used to investigate ground-water recharge and the sources of water contributing to streamflow. A number of factors affect the isotopic composition of precipitation. Dansgaard (1964) found that the delta deuterium $(\delta \mathrm{D})$ and delta $\mathrm{O}-18\left(\delta^{18} \mathrm{O}\right)$ contents of precipitation are affected by altitude, latitude, distance inland 

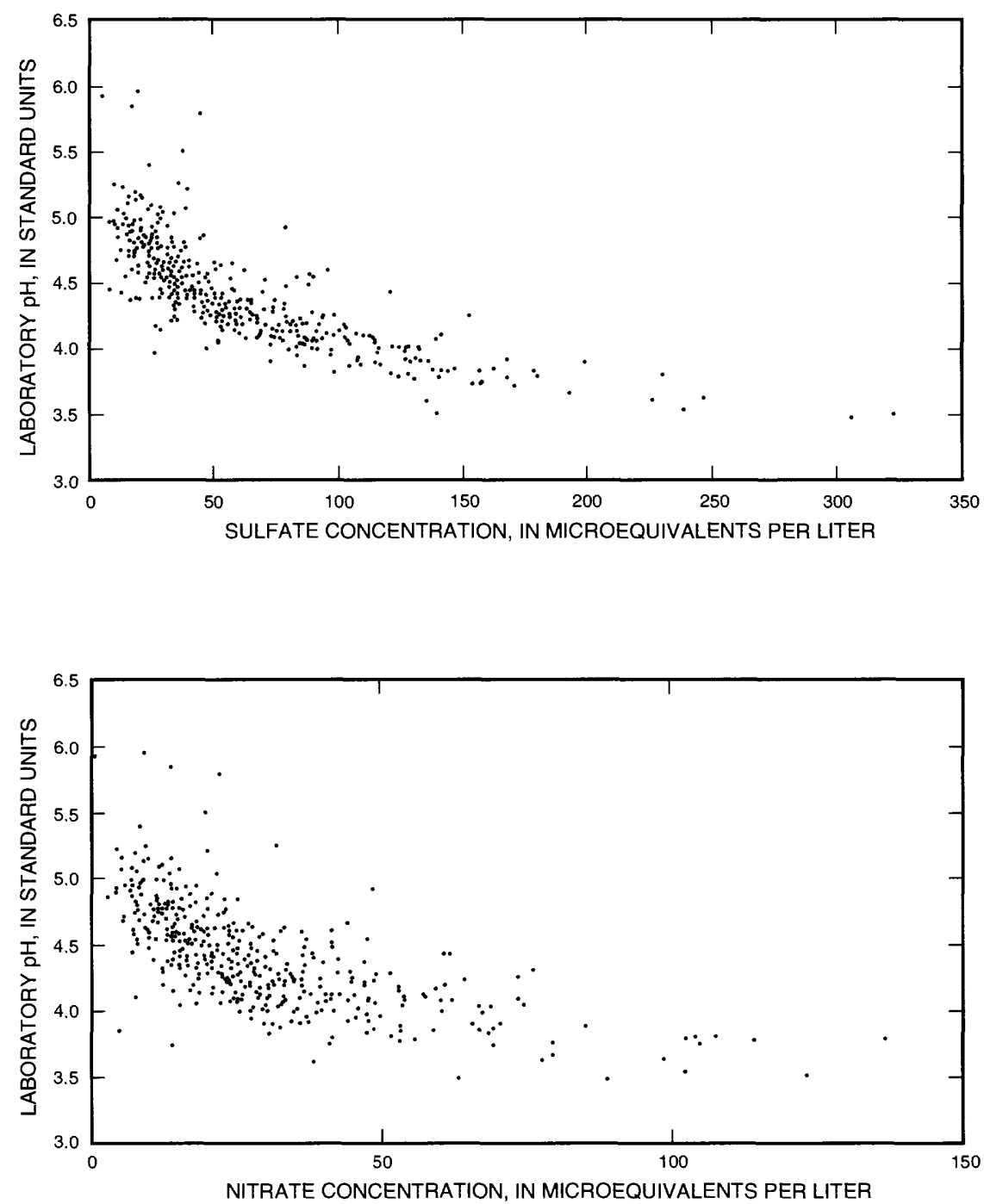

Figure 8. Variation in laboratory $\mathrm{pH}$ of precipitation collected from 1982-93 and sulfate and nitrate concentrations, Catoctin Mountain, Maryland. 
Table 9. Volume-weighted average concentrations of chemical constituents in precipitation on Catoctin Mountain, Maryland, 1982-93

[All concentrations in microequivalents per liter; $\mathrm{pH}$ in standard units; delta values in per mil (\%o); n.d., no data; mm, millimeters]

\begin{tabular}{|c|c|c|c|c|c|c|c|c|c|c|c|c|c|}
\hline \multirow[b]{2}{*}{ Year } & \multirow[b]{2}{*}{$\begin{array}{l}\text { Amount of } \\
\text { precipitation } \\
\text { used to } \\
\text { volume } \\
\text { weight } \\
\text { (mm) }\end{array}$} & \multirow[b]{2}{*}{$\begin{array}{c}\text { Field } \\
\text { hydrogen } \\
\text { ion } \\
(\mathrm{pH})\end{array}$} & \multirow[b]{2}{*}{$\begin{array}{l}\text { Laboratory } \\
\text { hydrogen } \\
\text { ion } \\
(\mathrm{pH})\end{array}$} & \multicolumn{7}{|c|}{ Volume-weighted average concentrations } & \multirow[b]{2}{*}{ Sulfate } & \multirow[b]{2}{*}{$\begin{array}{c}\text { Delta } \\
\text { D } \\
(\% 0)\end{array}$} & \multirow[b]{2}{*}{$\begin{array}{l}\text { Delta } \\
{ }^{18} \mathrm{O} \\
(\% 0)\end{array}$} \\
\hline & & & & Calcium & Magnesium & Sodium & Potassium & Ammonium & Chloride & Nitrate & & & \\
\hline 1982 & 834 & $\begin{array}{l}79.07 \\
(4.10)\end{array}$ & $\begin{array}{l}44.82 \\
(4.35)\end{array}$ & 8.52 & 2.10 & 9.96 & 2.69 & n.d. & 11.2 & 23.5 & 45.2 & n.d. & n.d. \\
\hline 1983 & 1,391 & $\begin{array}{l}75.41 \\
(4.12)\end{array}$ & $\begin{array}{l}48.75 \\
(4.31)\end{array}$ & 11.9 & 3.40 & 7.88 & 1.02 & n.d. & 16.5 & 23.0 & 51.2 & n.d. & n.d. \\
\hline 1984 & 1,439 & $\begin{array}{l}63.39 \\
(4.20)\end{array}$ & $\begin{array}{l}42.14 \\
(4.38)\end{array}$ & 13.2 & 2.39 & 11.0 & 1.88 & n.d. & 10.4 & 21.7 & 58.8 & n.d. & n.d. \\
\hline 1985 & 1,026 & $\begin{array}{l}47.71 \\
(4.32)\end{array}$ & $\begin{array}{l}35.70 \\
(4.45)\end{array}$ & 6.92 & 3.37 & 8.90 & 3.51 & n.d. & 10.2 & 19.1 & 43.2 & n.d. & n.d. \\
\hline 1986 & 933 & $\begin{array}{l}71.52 \\
(4.15)\end{array}$ & $\begin{array}{l}52.53 \\
(4.28)\end{array}$ & 10.7 & 2.22 & 6.01 & 1.85 & n.d. & 10.8 & 26.6 & 54.8 & n.d. & n.d. \\
\hline 1987 & 1,086 & $\begin{array}{l}54.18 \\
(4.27)\end{array}$ & $\begin{array}{l}47.32 \\
(4.32)\end{array}$ & 8.06 & 2.12 & 7.14 & 2.61 & n.d. & 14.8 & 27.6 & 60.7 & n.d. & n.d. \\
\hline 1988 & 922 & $\begin{array}{l}92.70 \\
(4.03)\end{array}$ & $\begin{array}{l}58.07 \\
(4.24)\end{array}$ & 8.67 & 2.51 & 5.24 & 2.28 & n.d. & 9.99 & 25.3 & 61.7 & n.d. & n.d. \\
\hline 1989 & 1,038 & $\begin{array}{l}50.67 \\
(4.30)\end{array}$ & $\begin{array}{l}44.86 \\
(4.35)\end{array}$ & 3.51 & 1.04 & 1.37 & 1.35 & n.d. & 4.89 & 20.0 & 44.0 & n.d. & n.d. \\
\hline 1990 & 1,261 & $\begin{array}{l}59.83 \\
(4.22)\end{array}$ & $\begin{array}{l}44.79 \\
(4.35)\end{array}$ & 7.33 & 2.71 & 6.93 & 2.35 & n.d. & 10.8 & 23.2 & 49.6 & n.d. & n.d. \\
\hline 1991 & 958 & $\begin{array}{l}77.31 \\
(4.11)\end{array}$ & $\begin{array}{l}42.83 \\
(4.37)\end{array}$ & 9.78 & 4.31 & 2.28 & 0.71 & n.d. & 9.79 & 25.4 & 56.5 & -47.9 & -8.03 \\
\hline 1992 & 1,199 & $\begin{array}{l}57.15 \\
(4.24)\end{array}$ & $\begin{array}{l}31.01 \\
(4.51)\end{array}$ & 7.70 & 2.83 & 2.65 & 0.41 & 13.3 & 7.53 & 19.5 & 40.8 & -45.0 & -7.63 \\
\hline 1993 & 1,116 & $\begin{array}{l}79.46 \\
(4.10)\end{array}$ & $\begin{array}{l}35.73 \\
(4.45)\end{array}$ & 5.13 & 5.71 & 3.82 & 0.86 & 14.7 & 7.13 & 21.1 & 44.2 & -51.3 & -8.27 \\
\hline $\begin{array}{l}\text { Volume-w } \\
\text { average for } \\
\text { 12-year } \\
\text { period of } \\
\text { record }\end{array}$ & 1,100 & $\begin{array}{l}68.67 \\
(4.16)\end{array}$ & $\begin{array}{l}45.49 \\
(4.34)\end{array}$ & 8.80 & 3.06 & 6.95 & 2.00 & n.d. & 11.8 & 23.6 & 51.3 & n.d. & n.d. \\
\hline
\end{tabular}


Table 10. Precipitation (wet deposition) loadings at Catoctin Mountain, Maryland, 1982-93

[All loading values in moles per hectare per year, n.a., not analyzed]

\begin{tabular}{|c|c|c|c|c|c|c|c|c|c|c|c|}
\hline \multirow[b]{2}{*}{ Year } & \multirow[b]{2}{*}{$\begin{array}{l}\text { Amount of } \\
\text { Precipitation } \\
\text { (millimeters) }\end{array}$} & \multicolumn{9}{|c|}{ Precipitation loadings } & \multirow[b]{2}{*}{ Sulfate } \\
\hline & & $\begin{array}{l}\text { Laboratory } \\
\text { hydrogen } \\
\text { ion }\end{array}$ & $\begin{array}{l}\text { Field } \\
\text { hydrogen } \\
\text { ion }\end{array}$ & Calcium & Magnesium & Sodium & Potassium & Ammonium & Chloride & Nitrate & \\
\hline 1982 & 937 & 440.72 & 767.88 & 40.10 & 9.90 & 91.97 & 25.11 & n.a. & 102.62 & 224.80 & 220.06 \\
\hline 1983 & 1,468 & 721.20 & $1,115.8$ & 87.37 & 24.95 & 116.25 & 15.09 & n.a. & 245.08 & 338.94 & 377.29 \\
\hline 1984 & 1,485 & 615.94 & 929.45 & 96.98 & 17.83 & 165.12 & 27.81 & n.a. & 157.85 & 320.43 & 430.90 \\
\hline 1985 & 1,119 & 393.04 & 523.62 & 38.18 & 19.33 & 104.84 & 40.63 & n.a. & 118.98 & 211.23 & 238.75 \\
\hline 1986 & 944 & 496.03 & 675.98 & 50.66 & 10.52 & 56.82 & 17.47 & n.a. & 101.91 & 232.66 & 258.76 \\
\hline 1987 & 1,095 & 517.02 & 592.26 & 44.12 & 11.58 & 78.32 & 28.61 & n.a. & 161.75 & 301.40 & 331.58 \\
\hline 1988 & 951 & 549.81 & 876.62 & 40.94 & 11.87 & 49.68 & 21.57 & n.a. & 94.77 & 239.47 & 291.82 \\
\hline 1989 & 1,082 & 478.26 & 539.09 & 18.64 & 5.54 & 14.39 & 14.65 & n.a. & 52.02 & 213.39 & 233.84 \\
\hline 1990 & 1,243 & 555.73 & 744.36 & 45.52 & 16.86 & 86.70 & 29.10 & n.a. & 134.14 & 288.25 & 307.88 \\
\hline 1991 & 964 & 413.38 & 745.85 & 47.15 & 20.82 & 21.94 & 6.81 & n.a. & 94.45 & 244.74 & 272.80 \\
\hline 1992 & 1,232 & 382.13 & 704.73 & 94.95 & 35.67 & 32.50 & 5.04 & 163.86 & 93.62 & 240.49 & 503.39 \\
\hline 1993 & 1,217 & 445.16 & 971.01 & 62.55 & 71.72 & 46.66 & 10.53 & 176.85 & 87.53 & 256.57 & 534.34 \\
\hline
\end{tabular}


from the coast, temperature, season, and the amount of precipitation. The linear relation between $\delta \mathrm{D}$ and $\delta^{18} \mathrm{O}$ in meteoric water is expressed by the equation $\delta D=m \delta^{18} O+d$, where $m$ is the slope and $d$ is the deuterium excess parameter. The global mean value of $d$ for freshwater is 10 (Craig, 1961); however, the value of $d$ may differ appreciably from area to area. In the Catoctin Mountain area of Maryland, the value of $d$ is 14.4, and the equation of the local meteoric water line (calculated using precipitation data collected from April 1990 through December 1993) is $\delta D=7.9 \delta^{18} O+14.4$.

The slope of any meteoric water line is a function of humidity; temperature, salt concentration, and other factors (Coplen, 1993). Two major processes that can affect the slope of a meteoric water line are evaporation and water-rock interaction. Evaporation enriches $\mathrm{D}$ and ${ }^{18} \mathrm{O}$ in the water and decreases the slope of the line. Therefore, waters that have evaporated will plot to the right of the meteoric water line on a graph showing the relation between $\delta \mathrm{D}$ and $\delta^{18} \mathrm{O}$. Water-rock interaction at earth-surface temperatures may increase the ${ }^{18} \mathrm{O}$ content of the rock, decrease the ${ }^{18} \mathrm{O}$ content of the water, and increase the D content of the water if hydrated secondary minerals are formed. Waters that have undergone extensive rock interactions will plot to the left of the meteoric water line on a graph showing the relation between $\delta \mathrm{D}$ and $\delta^{18} \mathrm{O}$.

The Catoctin meteoric water line (CMWL) and representative samples of the types of waters collected from the watersheds are shown in figure 9.

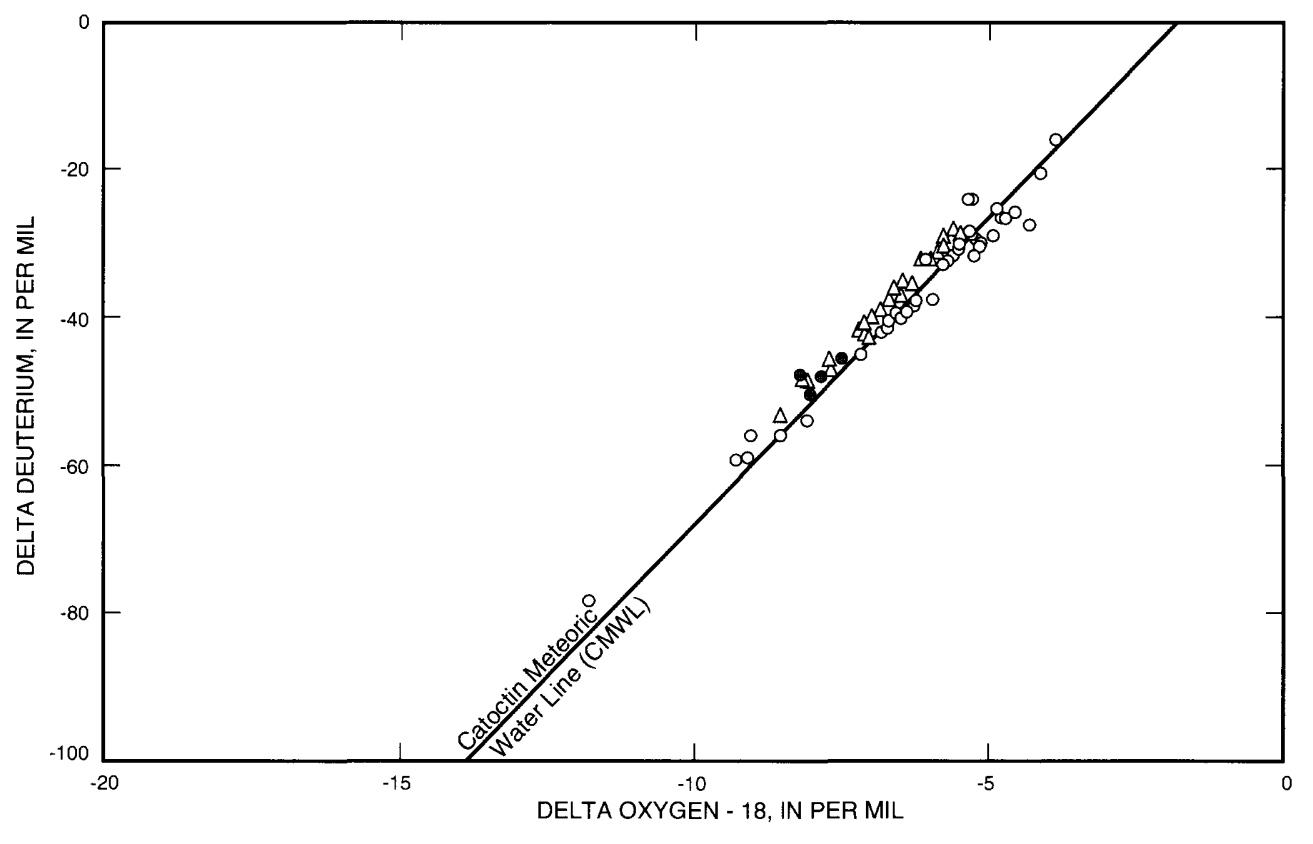

\section{EXPLANATION}

- SOIL WATER

- GROUND WATER

$\triangle$ STREAMWATER

Figure 9. The Catoctin meteoric water line (CMWL) and representative waters collected from the Bear Branch and Fishing Creek tributary watersheds, Catoctin Mountain, Maryland, 1991-93. 
The data collected from the watersheds plot on and in close proximity to the CMWL, which indicates that evaporation does not significantly affect the $\delta \mathrm{D}$ and $\delta^{18} \mathrm{O}$ content of the waters entering these watersheds. The small amount of water-rock interaction in these watersheds is overwhelmed by the large amount of water passing through the watershed, so that water-rock interactions do not significantly affect the $\delta \mathrm{D}$ and $\delta^{18} \mathrm{O}$ content of the waters. Thus, the major variations in $\delta \mathrm{D}$ and $\delta^{18} \mathrm{O}$ in the samples arise from differences in their compositions in atmospheric deposition.

Stable-isotope values of precipitation collected from the Catoctin Mountain precipitationcollection station show a seasonal pattern with the isotopically lightest (most negative) values from November to May and the heavier (least negative) values from June to October. For April 1990 through December 1993, $\delta \mathrm{D}$ and $\delta^{18} \mathrm{O}$ ranged from -141.6 to $+4.5 \%$ and -19.45 to $-0.7 \%$ o, respectively. Volume-weighted average values of $\delta \mathrm{D}$ and $\delta^{18} \mathrm{O}$ in precipitation for $1991-93$ are given in table 9.

\section{Throughfall}

Throughfall--precipitation that has contacted the forest canopy--is the next type of water that affects the hydrologic and geochemical responses of a watershed. The quantity of throughfall was spatially variable during individual rainstorms in both watersheds. For almost every rainstorm, more throughfall was recorded under the deciduous canopies than under the coniferous canopies, and as expected, as a result of canopy interception, the measured quantity of throughfall in the watersheds was less than the quantity of precipitation that was recorded at the precipitation-collection station.

Individual samples from each throughfall collector were not analyzed for water chemistry or isotopic composition due to limited resources.

However, it is suspected that had individual samples been analyzed, a large variability in water quality among the samples would have been observed (Puckett, 1991). A large variability in the chemistry of the composite samples was observed from storm to storm, and a difference in chemistry was ob- served between samples collected beneath deciduous and coniferous canopies. In general, both deciduous and coniferous throughfall was more concentrated than precipitation in all constituents analyzed, except for $\mathrm{H}^{+}$ion. Coniferous throughfall at the Bear Branch study site was slightly more concentrated than deciduous throughfall, except for $\mathrm{K}^{+}$ and the ANC, which were slightly less in coniferous throughfall, and $\mathrm{Na}^{+}$and $\mathrm{SiO}_{2}$, which were about equal in throughfall collected under both types of canopies (fig. 5).

Throughfall deposition loadings were calculated for each full year that data were collected for this study (1991-93). However, for 1991 and 1992, throughfall samples were not collected during the winter months. For the periods of missing throughfall data, concentrations of ions in precipitation were used to calculate the loadings. The throughfall loadings for the Bear Branch and Fishing Creek tributary watersheds, in moles per hectare per year, are shown in table 11. The throughfall loadings must be considered as maximum loadings because no attempt was made to quantify the amount of internal recycling of nutrients through the biomass in these watersheds.

\section{Soil Water}

Soil water--water that has drained by gravity through a portion of the unsaturated zone in the soil horizon--is another water type that affects the hydrologic and geochemical responses of a watershed. The quantity of soil water collected from each lysimeter was not accurately measured; only an approximation of the amount of water collected in the 3.8-L jug was recorded. For that reason, no rigorous comparisons between the amount of precipitation and the amount of water collected in the lysimeters can be made. However, some generalizations can be made about the amount of soil water collected.

In the Bear Branch watershed, more soil water usually was collected from the upper pans in lysimter pit 1 than from the upper pans in lysimeter pit 2. Pit 1 is located on a much steeper slope than pit 2. This suggests that additional water, perhaps flowing from upslope more or less parallel to land 
Table 11. Throughfall loadings in the Bear Branch and Fishing Creek tributary watersheds, Catoctin Mountain, Maryland, $1991-93$

[All loading values in moles per hectare per year, n.a., not analyzed]

\begin{tabular}{|c|c|c|c|c|c|c|c|c|c|c|c|c|}
\hline \multirow[b]{2}{*}{ Year } & \multirow{2}{*}{$\begin{array}{l}\text { Amount of } \\
\text { precipitation } \\
\text { (millimeters) }\end{array}$} & \multicolumn{10}{|c|}{ Throughfall loadings } & \multirow[b]{2}{*}{ Silica } \\
\hline & & $\begin{array}{c}\text { Laboratory } \\
\text { hydrogen ion }\end{array}$ & $\begin{array}{c}\text { Field } \\
\text { hydrogen ion }\end{array}$ & Calcium & Magnesium & Sodium & Potassium & Chloride & Nitrate & Sulfate & $\begin{array}{c}\text { Acid-neutralizing } \\
\text { capacity }\end{array}$ & \\
\hline \multicolumn{13}{|c|}{ Bear Branch coniferous throughfall } \\
\hline 1991 & 887 & 259.53 & 510.54 & 152.14 & 65.92 & 35.49 & 415.85 & 135.65 & 349.23 & 390.0 & n.a. & 4.58 \\
\hline 1992 & 1,164 & 348.75 & 509.40 & 314.88 & 135.59 & 91.55 & 548.21 & 262.99 & 580.42 & 619.66 & 16.37 & n.a. \\
\hline 1993 & 953 & 718.83 & $1,142.97$ & 303.52 & 96.14 & 242.12 & 361.78 & 358.85 & 821.58 & 531.64 & 55.02 & 6.13 \\
\hline \multicolumn{13}{|c|}{ Bear Branch deciduous throughfall } \\
\hline 1991 & 903 & 305.18 & 534.55 & 143.40 & 63.57 & 32.50 & 382.14 & 103.84 & 259.35 & 332.67 & n.a. & 7.66 \\
\hline 1992 & 1,164 & 220.68 & 301.96 & 281.24 & 134.71 & 79.77 & 784.49 & 186.49 & 206.01 & 448.98 & 447.97 & n.a. \\
\hline 1993 & 1,075 & 400.73 & 545.08 & 292.56 & 120.59 & 157.86 & 670.62 & 242.29 & 421.08 & 455.7 & 286.93 & 10.11 \\
\hline \multicolumn{13}{|c|}{ Fishing Creek tributary deciduous throughfall } \\
\hline 1991 & 844 & 242.23 & 480.51 & 112.81 & 52.82 & 30.99 & 138.16 & 108.64 & 237.93 & 256.82 & 14.46 & 4.32 \\
\hline 1992 & 1,236 & 281.64 & 416.06 & 175.10 & 116.99 & 75.87 & 485.66 & 202.25 & 269.02 & 396.97 & 182.29 & n.a. \\
\hline 1993 & 814 & 314.82 & 448.83 & 166.56 & 88.59 & 74.7 & 270.7 & 130.82 & 321.98 & 299.27 & 108.89 & n.a. \\
\hline
\end{tabular}


surface, may have been intercepted by the pit 1 lysimeter. Additional evidence that this may be the case is that no samples were ever collected from the lower pans in pit 1 . The upper pans in pit 2 usually collected more water than the lower pans but not always. This suggests that precipitation that fell prior to the week preceding lysimeter sample collection may have drained by gravity more slowly and contributed to the amount of sample collected.

In the Fishing Creek tributary watershed, more soil water was usually collected from the upper pans in lysimeter pit 1 than from the upper pans in pit 2. Pit 2 is located on a steeper slope than pit 1 . The amount of soil water collected from the lysimeter on the steeper slope in the Fishing Creek tributary watershed is opposite to that collected in the Bear Branch watershed, where the upper lysimeter on the steeper slope appeared to intercept more water than the upper lysimeter on the less-steep slope. The upper pans in pit 2 of the Fishing Creek tributary watershed usually collected more soil water than the middle pans of pit 2, but like in the Bear Branch watershed, this was not always the case. No samples were ever collected from the lower pans of the Fishing Creek tributary pit 2 lysimeter. The only conclusion that can be drawn from the amounts of soil water collected from each of the lysimeters is that the quantity collected was spatially variable--from pit to pit and with depth in an individual pit. This spatial variability probably reflects an uneven distribution of macropores in the soil profile.

Individual samples from each lysimeter pit and depth were collected and analyzed. In general, the upper soil waters were more acidic and more concentrated in $\mathrm{NO}_{3}{ }^{-}$and less concentrated in $\mathrm{Mg}^{2+}$, $\mathrm{Na}^{+}, \mathrm{Cl}^{-}, \mathrm{SO}_{4}{ }^{2-}, \mathrm{ANC}$, and $\mathrm{SiO}_{2}$ than the lower soil waters. Concentrations of $\mathrm{Ca}^{2+}, \mathrm{K}^{+}$, and $\mathrm{Al}^{3+}$ were variable at different depths in all of the lysimeter pits. Box plots showing major constituent concentrations in the upper and lower soil waters from the two lysimeter pits in each watershed are shown in figures 10 and 11, respectively. For Fishing Creek tributary pit 2 , samples collected from the middle set of pans are shown as lower soil waters in figure 11.

\section{Ground Water}

Ground water--water below the water table and in the zone of saturation--is the final type of water that can affect the hydrologic and geochemical responses of a watershed discussed in this report. Depth to the ground-water table near the streams in the two watersheds is generally shallow (fig. 6). The depth to the water table fluctuates seasonally in response to changes in rates of evapotranspiration that affect recharge (fig. 12). In the Bear Branch watershed, the water table annually ranges from $0.48 \mathrm{~m}$ below land surface in well point 2 to more than $2.80 \mathrm{~m}$ below land surface in well point 3 . Short-term fluctuations in the ground-water table in response to individual storms in each of the watersheds also were observed (fig. 12).

The ground-water system underlying the watersheds described in this report is considered to be unconfined. In two other watersheds on Catoctin Mountain, there appears to be hydraulic connection between the fractured bedrock aquifer and the overlying regolith (Rice and Bricker, 1995a). The regional direction of ground-water flow is toward larger streams in the area, which represent base level for the region. For the Bear Branch watershed, base level for the deeper ground water is Hunting Creek (fig. 2), which causes most of the ground water to flow parallel to Bear Branch and discharge into Hunting Creek.

Superimposed on the regional pattern of ground-water flow is the local pattern of groundwater flow in the watersheds. Ground-water levels in the near-stream wells (fig. 12) indicate that the ground water that supplies base flow to Bear Branch is the near-stream shallow ground water, which follows local flow paths. Ground-water flow in the Bear Branch watershed is probably similar to the Fishing Creek tributary watershed, where base level for deep ground water is Fishing Creek (fig. 2). Just upstream of the streamflow-gaging station on Fishing Creek tributary, the topography is relatively flat, and the area is filled with boulders. Beneath this broad, flat flood plain, near-surface ground water flows parallel to the stream valley. Where the shallow ground water intersects the stream channel, it contributes to streamflow. 

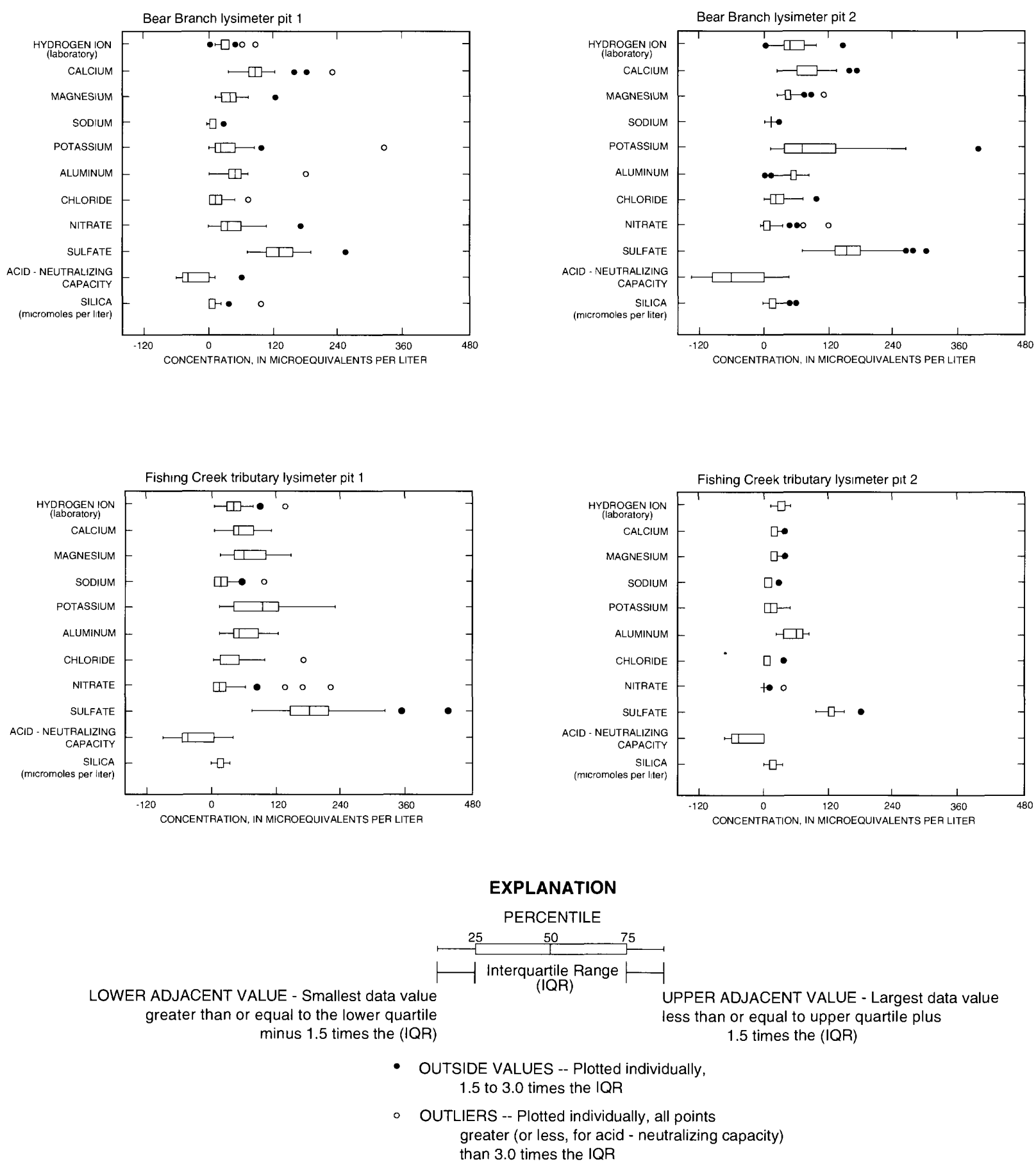

Figure 10. Major inorganic constituent concentrations in upper soil water from lysimeter pits in the Bear Branch and Fishing Creek tributary watersheds, Catoctin Mountain, Maryland, 1991-93. 

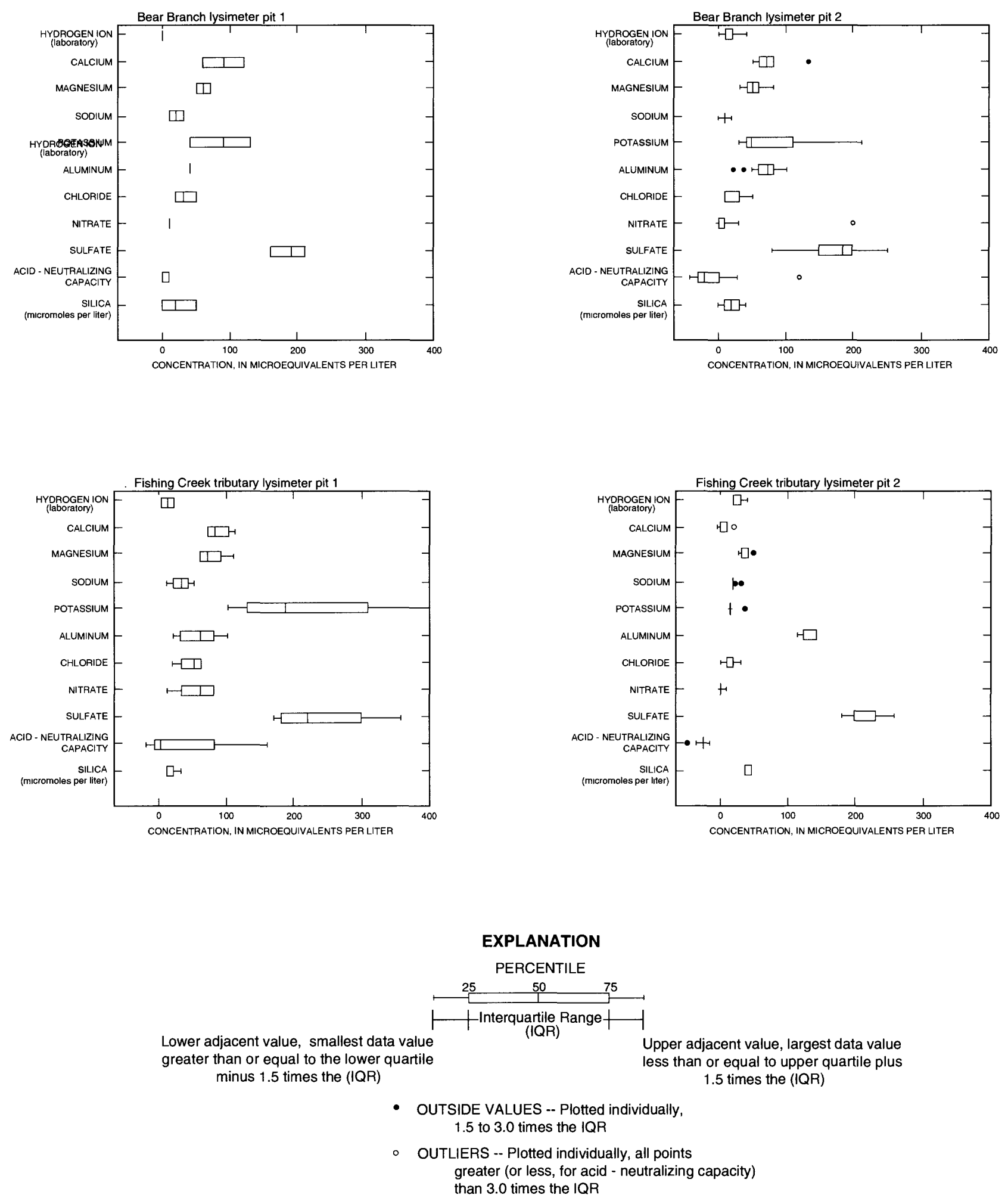

Figure 11. Major inorganic constituent concentrations in lower soil water from lysimeter pits in the Bear Branch and Fishing Creek tributary watersheds, Catoctin Mountain, Maryland, 1991-93. 


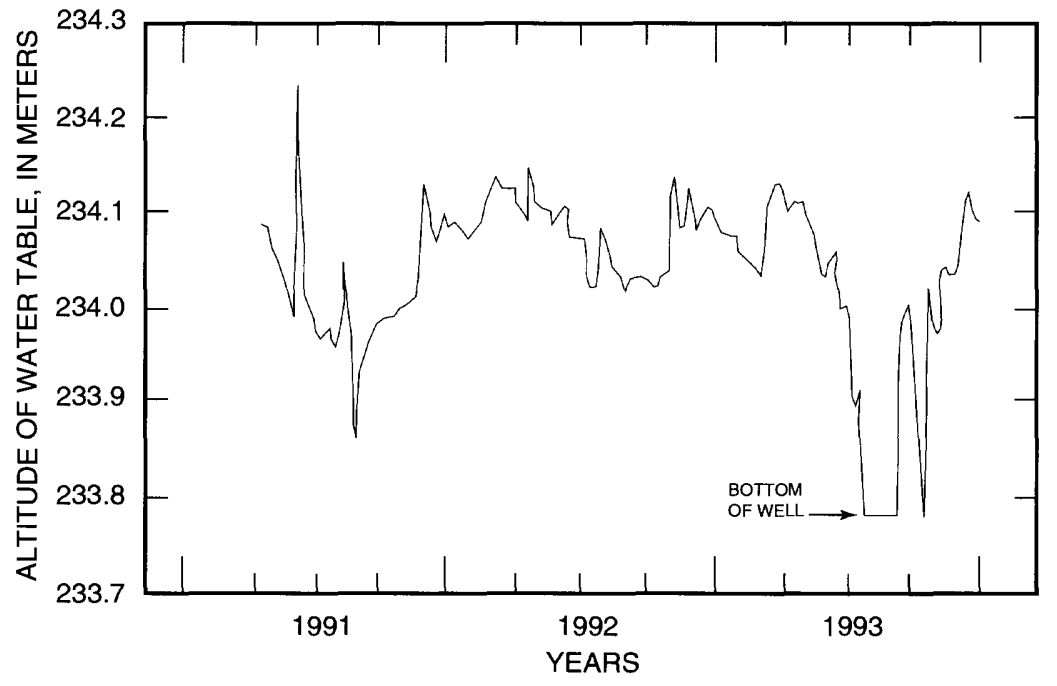

Figure 12. Seasonal fluctuations in altitude of water table in Bear Branch well point 4, Catoctin Mountain, Maryland, April 1991 through December 1993.

The chemistry of near-stream shallow ground water in the two watersheds is relatively stable throughout the year and is similar in concentration and composition, with the exception of the ANC and the concentration of $\mathrm{SiO}_{2}$. The $\mathrm{ANC}$ and the concentration of $\mathrm{SiO}_{2}$ in shallow ground water in the Bear Branch watershed are less than those in near-stream shallow ground water in the Fishing Creek tributary watershed (fig. 5).

\section{Streamwater}

For the period of record for Bear Branch (1991-93), the annual runoff to rainfall ratio ranged from a low of 0.42 in 1991 to a high of 0.63 in 1993. For the period of record for Fishing Creek tributary (1988-93), the annual runoff to rainfall ratio ranged from a low of 0.35 in 1990 to a high of 0.62 in 1993. For the period of record common for the two watersheds (1991-93), the annual runoff to rainfall ratio was very similar between the two watersheds (for 1991, Bear Branch was 0.42, Fishing Creek tributary was 0.41 ; for 1992 , Bear Branch was 0.52 , Fishing Creek tributary was 0.50 ; for 1993 , Bear Branch was 0.63, Fishing Creek tributary was 0.62).
The ratios for the period of record (1988-93) for Fishing Creek tributary indicate that, on an average annual basis, approximately 46 percent of the incoming precipitation runs off as streamflow, whereas part of the other 54 percent of the precipitation is evapotranspired and part of it recharged the groundwater system.

The response of the streams to rainfall is rapid, with a rise in stage recorded within the first 30 minutes after the inception of rainfall. Snowmelt usually does not produce as dramatic a rise in streamflow as does rainfall; some snowpacks melted without producing any rise in stage. This indicates that recharge to the soil-water deficit or to ground water may occur during these times. The response of these streams to snowmelt is in contrast to that of streams farther to the north where a deeper snowpack is present that, when melted, causes a spring "flush out" of water and $\mathrm{NO}_{3}{ }^{-}$from the watershed (Murdoch, 1991).

Annual exports of the constituents analyzed were calculated for both watersheds for the appropriate periods of record. The exports were calculat- 
ed on the basis of the period-weighted method of summing discharge. For example, when samples were collected weekly, the mean daily discharges for the 3 days prior to the sample date, the 3 days after the sample date, and the discharge on the sample date were summed to give a total discharge that was then multiplied by the concentrations of each constituent. The products of the discharges and concentrations then were summed and multiplied by a conversion factor to determine the annual export of each constituent. The export calculations for both watersheds for the periods of record are given in table 12.

\section{Base Flow}

Base flow, which is the amount of streamflow provided by discharging ground water, in both streams shows strong seasonal fluctuations (fig. 13). Base flow is highest during the winter and spring and gradually declines throughout the summer and fall. Short periods of increased discharge from storm-runoff episodes are superimposed on the annual seasonal pattern of base flow. The strong seasonal pattern of base flow is related to seasonal fluctuations in the ground-water table, which are related to evapotranspiration rates. Evapotranspiration rates are highest in late spring and summer and cause a decrease in the amount of base flow in the stream during that time.

Base flow of the two streams was estimated using a graphical hydrograph-separation technique. On a hydrograph of the stream, a continuous line was drawn that coincided with the lowest flows and that included part of the stormflow peaks. The mean daily discharge on the sample date then was compared with the continuous line drawn on the hydrograph. If the discharge on the sample date was equal to the discharge that the line represented, the sample was considered to have been collected during base-flow conditions. If the discharge on the sample date was greater than the discharge that the line represented, the sample was considered to have been collected during stormflow conditions. An example of the hydrograph-separation line for the first year of Fishing Creek tributary streamflow record is shown on figure 13.
On the average, approximately 69 percent of total annual streamflow in both watersheds consisted of base flow. Trainer and Watkins (1975) reported that the base-flow contribution to total streamflow in streams draining fracture-flow terrain in the upper Potomac River Basin ranged from 39 to 61 percent. Box plots of major constituent concentrations in streamwater base flow collected from Bear Branch and Fishing Creek tributary are shown in figure 5.

\section{Stormflow}

Stormflow of the two streams was considered as any flow not defined as base flow and that caused a peak in the hydrograph. On the average, approximately 31 percent of total annual streamflow in both watersheds consisted of stormflow.

The stormflow parts of the hydrographs indicate that both streams have broader peaks during the nongrowing season (mid-October to mid-May) than during the growing season (mid-May to midOctober). During the growing season, the stormflow parts of the hydrographs for both streams tend to have sharp peaks and rapid recessions. Bear Branch had a wider range in annual fluctuations in mean daily streamflow than Fishing Creek tributary (for 1991, Bear Branch was 1 to $102 \mathrm{~L} / \mathrm{s}$ and Fishing Creek tributary was 1 to $54 \mathrm{~L} / \mathrm{s}$; for 1992 , Bear Branch was 3 to $266 \mathrm{~L} / \mathrm{s}$ and Fishing Creek tributary was 2 to $226 \mathrm{~L} / \mathrm{s}$; for 1993, Bear Branch was 1 to $510 \mathrm{~L} / \mathrm{s}$ and Fishing Creek tributary was 1 to 158 $\mathrm{L} / \mathrm{s}$ ). Bear Branch maintained a slightly higher mean daily streamflow during the nongrowing season (1991 was $21 \mathrm{~L} / \mathrm{s} ; 1992$ was $29 \mathrm{~L} / \mathrm{s}$; 1993 was $41 \mathrm{~L} / \mathrm{s}$ ) than did Fishing Creek tributary (1991 was $20 \mathrm{~L} / \mathrm{s} ; 1992$ was $25 \mathrm{~L} / \mathrm{s} ; 1993$ was $41 \mathrm{~L} / \mathrm{s}$ ). However, during the growing season, Fishing Creek tributary maintained a slightly higher mean daily streamflow (1991 was $6 \mathrm{~L} / \mathrm{s} ; 1992$ was $15 \mathrm{~L} / \mathrm{s} ; 1993$ was $8 \mathrm{~L} / \mathrm{s}$ ) than did Bear Branch (1991was $4 \mathrm{~L} / \mathrm{s}$; 1992 was $11 \mathrm{~L} / \mathrm{s} ; 1993$ was $7 \mathrm{~L} / \mathrm{s}$ ). In general, both streams discharge a greater amount of water for a given rainstorm during the nongrowing season because the water table and, as a consequence, base flow, is higher during the nongrowing season than during the growing season. Less evapotranspiration during the winter, when vegetation is dormant 
Table 12. Annual export of chemical constituents in streamwater of Bear Branch (1991-93) and Fishing Creek tributary (1988-93), Catoctin Mountain, Maryland

[Annual discharge in liters per second; chemical constituent data in moles per hectare per year; n.d., not determined; annual discharge in liters per second]

\begin{tabular}{|c|c|c|c|c|c|c|c|c|c|c|c|c|c|c|}
\hline \multirow[b]{2}{*}{ Year } & \multicolumn{14}{|c|}{ Annual export of chemical constituents } \\
\hline & $\begin{array}{c}\text { Annual } \\
\text { discharge }\end{array}$ & $\begin{array}{c}\text { Laboratory } \\
\text { hydrogen } \\
\text { ion }\end{array}$ & $\begin{array}{c}\text { Field } \\
\text { hydrogen } \\
\text { ion }\end{array}$ & Calcium & Magnesium & Sodium & Potassium & Aluminum & Iron & Chloride & Nitrate & Sulfate & $\begin{array}{c}\text { Acid-neutralizing } \\
\text { capacity }\end{array}$ & Silica \\
\hline \multicolumn{15}{|c|}{ Bear Branch } \\
\hline 1991 & 4,632 & 12.3 & 14.4 & 112 & 129 & 130 & 102 & 6.59 & 0.42 & 161 & 164 & 205 & 12 & 340 \\
\hline 1992 & 7,380 & 35.3 & 35.5 & 179 & 208 & 199 & 156 & 16.5 & 1.41 & 245 & 179 & 361 & 11.6 & 535 \\
\hline 1993 & 8,771 & 43.8 & 62.8 & 207 & 252 & 220 & 196 & 24.4 & 0.74 & 257 & 208 & 471 & 6 & 604 \\
\hline \multicolumn{15}{|c|}{ Fishing Creek tributary } \\
\hline 1988 & 5,510 & 2.11 & 4.10 & 66.3 & 98.9 & 198 & 106 & n.d. & n.d. & 201 & 28.7 & 105 & 203 & 501 \\
\hline 1989 & 5,355 & 3.15 & 3.20 & 61.7 & 98.8 & 174 & 100 & n.d. & n.d. & 155 & 36.7 & 118 & 156 & 468 \\
\hline 1990 & 5,263 & 2.20 & 2.51 & 66.9 & 102 & 177 & 100 & n.d. & n.d. & 164 & 46.8 & 111 & 177 & 489 \\
\hline 1991 & 4,733 & 2.99 & 1.81 & 57.7 & 85.0 & 166 & 87.6 & n.d. & n.d. & 147 & 50.9 & 85.2 & 165 & 439 \\
\hline 1992 & 7,396 & 6.28 & 3.87 & 88.0 & 133 & 256 & 138 & n.d. & n.d. & 217 & 56.1 & 144 & 263 & 699 \\
\hline 1993 & 8,989 & 6.57 & 6.17 & 107 & 174 & 303 & 176 & 21.4 & n.d. & 266 & 97.3 & 188 & 294 & 771 \\
\hline
\end{tabular}



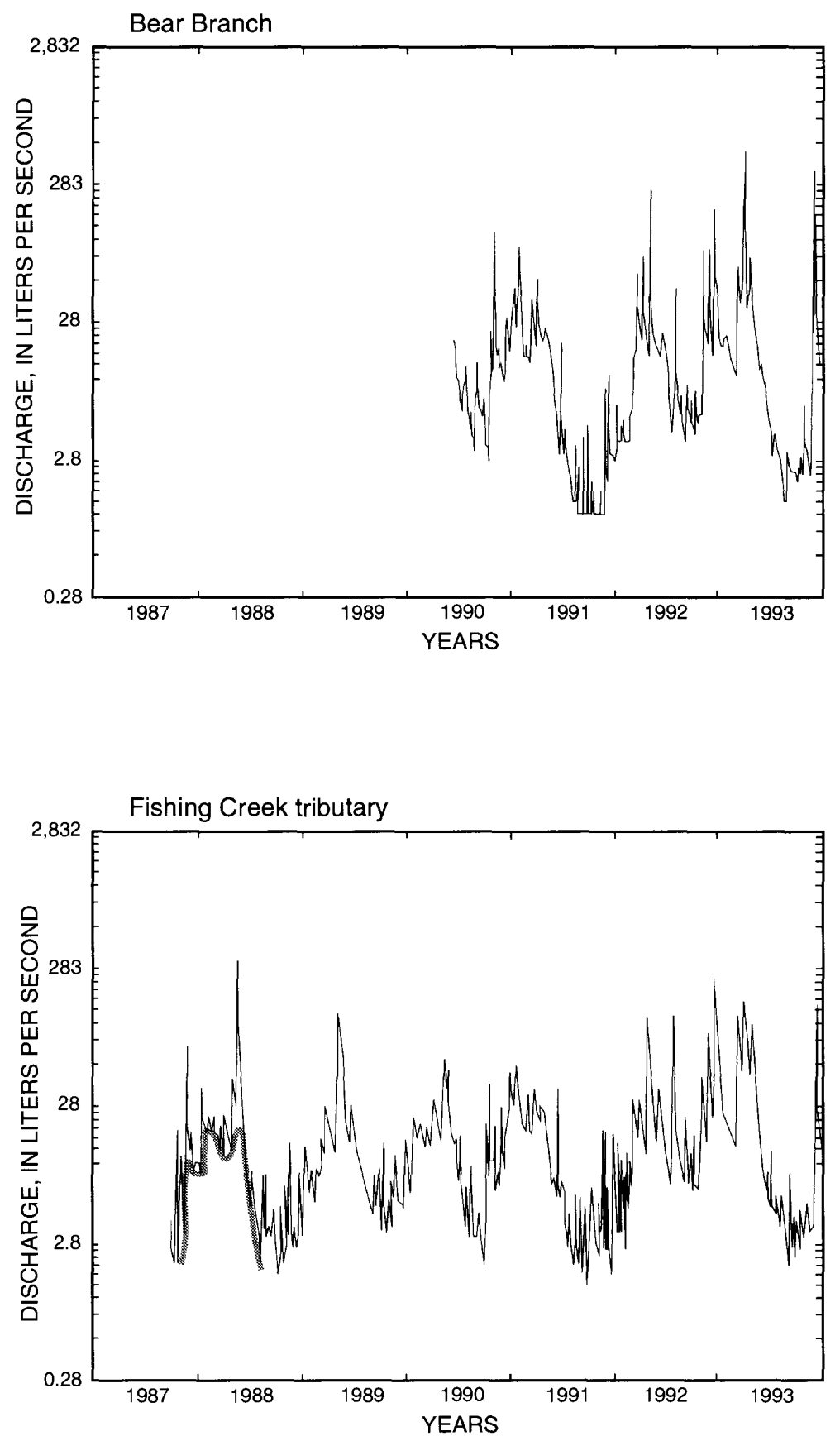

EXPLANATION

EXAMPLE OF BASE-FLOW - STORMFLOW HYDROGRAPH SEPARATION LINE

Figure 13. Mean daily discharge of Bear Branch, 1990-93, and Fishing Creek tributary, 1987-93, Catoctin Mountain, Maryland, and example of graphical hydrograph separation into base-flow and stormflow conditions. 
and the temperature is cooler, results in a higher water table than during the growing season.

Comparison of the data in figure 5 shows that the chemical composition of stormflow in these streams changes relative to that of base flow. In general, concentrations of $\mathrm{Ca}^{2+}, \mathrm{Mg}^{2+}, \mathrm{K}^{+}, \mathrm{H}^{+}$, $\mathrm{SO}_{4}{ }^{2-}, \mathrm{NO}_{3}{ }^{-}$, and $\mathrm{Al}^{3+}$ increase during stormflow, whereas the ANC and the concentration of $\mathrm{SiO}_{2}$ decrease.

\section{Comparison of Water Chemistry in the Two Watersheds}

The chemistry of all the types of waters sampled in the two watersheds from 1990 to 1993 can be compared by referring to figure 5 . The box plots for soil waters in figure 5 were created by incorporating all of the soil-water data from each level at each site into one box plot in contrast to figures 10 and 11 , which show the soil-water data divided into separate box plots for each level in each lysimeter pit.

All types of waters in both watersheds are acidic but generally become more buffered as they move through the watersheds, from precipitation to throughfall, through the soil zone, to shallow ground water, and finally to streamwater. The changes observed in the chemistry of stormflow in both catchments are similar, but a higher variability in concentrations was found in Fishing Creek tributary than Bear Branch. The "buffering" of the acidic precipitation input to these watersheds, largely due to weathering reactions, results in decreased $\mathrm{H}^{+}$-ion concentration and an increase in the ANC and concentrations of base cations and dissolved $\mathrm{SiO}_{2}$ by the time the water reaches the stream. The "increased concentrations" of base cations, the $\mathrm{ANC}$, and $\mathrm{SiO}_{2}$ in streamwater, although greater than concentrations in the acidic input water to these watersheds, are relatively small compared to the increases observed in other forested watersheds on Catoctin Mountain. This difference is directly related to the various types of bedrock that underlie the watersheds on Catoctin Mountain and reflects the low reactivity of minerals in the Weverton Formation (Bricker and Rice, 1989).
Aluminum concentrations are higher in the soil water in both watersheds and lower in ground water and streamwater. Increases in $\mathrm{Cl}^{-}$concentrations as the water moves through the watersheds indicate a concentration factor from evaporation of two to three times; therefore, evaporation does not greatly affect these systems (also see fig. 9). Nitrate concentrations in the waters are variable as a result of the role of $\mathrm{NO}_{3}{ }^{-}$in the biological cycle. Sulfate concentrations progressively increase from precipitation to throughfall through the soil zone. The increase in $\mathrm{SO}_{4}{ }^{2-}$ concentration in throughfall relative to precipitation suggests that the tree canopies act as receptors for dry deposition of acidic particles. Sulfate concentrations in the water increase even more as water travels through the unsaturated zone, indicating that a source of $\mathrm{SO}_{4}{ }^{2-}$ may be present. The large decrease in $\mathrm{SO}_{4}{ }^{2-}$ concentration from lower soil water to shallow ground water suggests that $\mathrm{SO}_{4}{ }^{2-}$ either (1) becomes immobilized in the soil zone through adsorption or precipitation as $\mathrm{SO}_{4}{ }^{2-}$ salts between storms or (2) becomes reduced in the zone between deep soil water and shallow ground water. The fate of $\mathrm{SO}_{4}{ }^{2-}$ in these watersheds is discussed in more detail in the section entitled "Geochemical Factors."

The ranges in stable-isotope concentrations of the input waters decrease as the waters move through the watersheds. Precipitation shows the widest range in stable-isotope concentration, followed by throughfall, upper soil water, lower soil water, and ground water. The isotopic composition of base flow is nearly identical to that of nearstream shallow ground water. The isotopic composition of stormflow, however, shows a much wider range of concentrations than the composition of base flow.

\section{HYDROLOGIC AND GEOCHEMICAL FACTORS AFFECTING CHEMISTRY OF HEADWATER STREAMS}

Acidic deposition and its effects on small watersheds in general and specifically on the Catoctin Mountain study sites are addressed in the following sections. Interpretation of the hydrologic and geochemical factors that affect the chemistry of the headwater streams, the storm hydrograph separa- 
tions, and a comparison of storm data are given. A discussion of the transferability and limitations of the results of this study is included.

\section{General Effects of Acidic Deposition}

Acidic deposition affects watershed systems in two ways. First, long-term continuing acidic deposition depletes the buffer capacity of the watershed and can cause chronic acidification of the watershed. Depending upon the characteristics of the particular watershed, this process may take many years but eventually can lead to the loss of aquatic biota from streams and lakes. Second, in addition to chronic acidification, streams can acidify episodically. Episodic acidification occurs as an immediate result of acidic rainfall or, in regions that develop a snowpack in winter, from spring snowmelt. During episodic acidification, which may have a duration of hours to weeks, stream $\mathrm{pH}$ and ANC decrease; the decrease in $\mathrm{pH}$ can be accompanied by an increase in dissolved $\mathrm{Al}^{3+}$ (fig. 14). The combination of decreased $\mathrm{pH}$ and increased $\mathrm{Al}^{3+}$ is toxic to aquatic organisms, and if severe, can result in fish kills. A stream that has generally suitable water quality throughout most of the year may be devoid of fish or exhibit a depauperate community if short-duration episodic acidification occurs in the stream. In some streams, the repetition of episodic acidification over a period of time can lead to chronic acidification. Thus, sampling of streams during stormflow and snowmelt, as well as during base flow, is necessary to assess the effects of acidic deposition on streamwater chemistry and aquatic biota.

One of the underlying causes of acidification in watersheds is the contribution of large amounts of sulfate (in the form of $\mathrm{H}_{2} \mathrm{SO}_{4}$ ) to watersheds by way of acidic deposition. Streams draining watersheds with elevated $\mathrm{H}_{2} \mathrm{SO}_{4}$ loadings from acidic deposition usually have elevated $\mathrm{SO}_{4}{ }^{2-}$ concentrations, even if the watershed has no internal source of $\mathrm{S}$. As the $\mathrm{H}_{2} \mathrm{SO}_{4}$ loading continues and acidification progresses, $\mathrm{SO}_{4}{ }^{2-}$ concentrations in streamwater become higher than the ANC. In some watersheds with large soil anion-sorption capacities, acidification of the streamwaters may be delayed by storage of $\mathrm{SO}_{4}{ }^{2-}$ on sorption sites. When the sorption capac- ity is exceeded, $\mathrm{SO}_{4}{ }^{2-}$ passes directly through the watershed system, at first balanced by base cations $\left(\mathrm{Ca}^{2+}, \mathrm{Mg}^{2+}, \mathrm{Na}^{+}, \mathrm{K}^{+}\right) . \mathrm{As}_{2} \mathrm{SO}_{4}$ loading continues, the watershed becomes depleted of the base cations, and the $\mathrm{SO}_{4}{ }^{2-}$ in streamwater is balanced by $\mathrm{H}^{+}$and $\mathrm{Al}^{3+}$. When the base cations are depleted, the waters become acidic and usually contain elevated concentrations of dissolved $\mathrm{Al}^{3+}$. This is also observed over short time periods when storms deposit more water than can infiltrate into the deep regolith and bedrock aquifer. The excess water is routed through the shallow subsurface, where little anionsorption capacity is left, directly to the streamwaters. This causes episodic acidification. Both the Bear Branch and Fishing Creek tributary watersheds currently receive larger $\mathrm{SO}_{4}{ }^{2-}$ inputs from atmospheric deposition than are exported in stream discharge. This means that the $\mathrm{SO}_{4}{ }^{2-}$ sorption capacity has not yet been exceeded in these watersheds. However, episodic acidification is indicated in both streams.

Ground water and streamwater in watersheds receiving the same atmospheric deposition may indicate quite different chemical responses depending upon specific watershed characteristics. Two of the most important factors governing the effects of atmospheric deposition on water chemistry are: (1) the type of bedrock underlying the watershed (for example, Meybeck, 1984; Bricker and Rice, 1989), and (2) the hydrologic pathways (shallow or deep) along which water moves through the system (for example, Pilgrim and others, 1979; Turk and Campbell, 1984; Rice and Bricker, 1995a). The reactivity of the minerals in the bedrock determines the capacity of the watershed system to neutralize acidic inputs, and the pathways along which water moves affects both the minerals the water contacts and the residence time of the water in contact with the minerals. In most watersheds, even those that have been subjected to severe weathering, usually some reactive minerals are distributed through the regolith (Velbel, 1992). Therefore, some weathering and neutralization of acids may occur in the regolith. The paucity of reactive minerals in the regolith relative to those in the bedrock and the shorter residence time of water indicate that the regolith is less important than the bedrock with respect to neutralization of acidic inputs. 

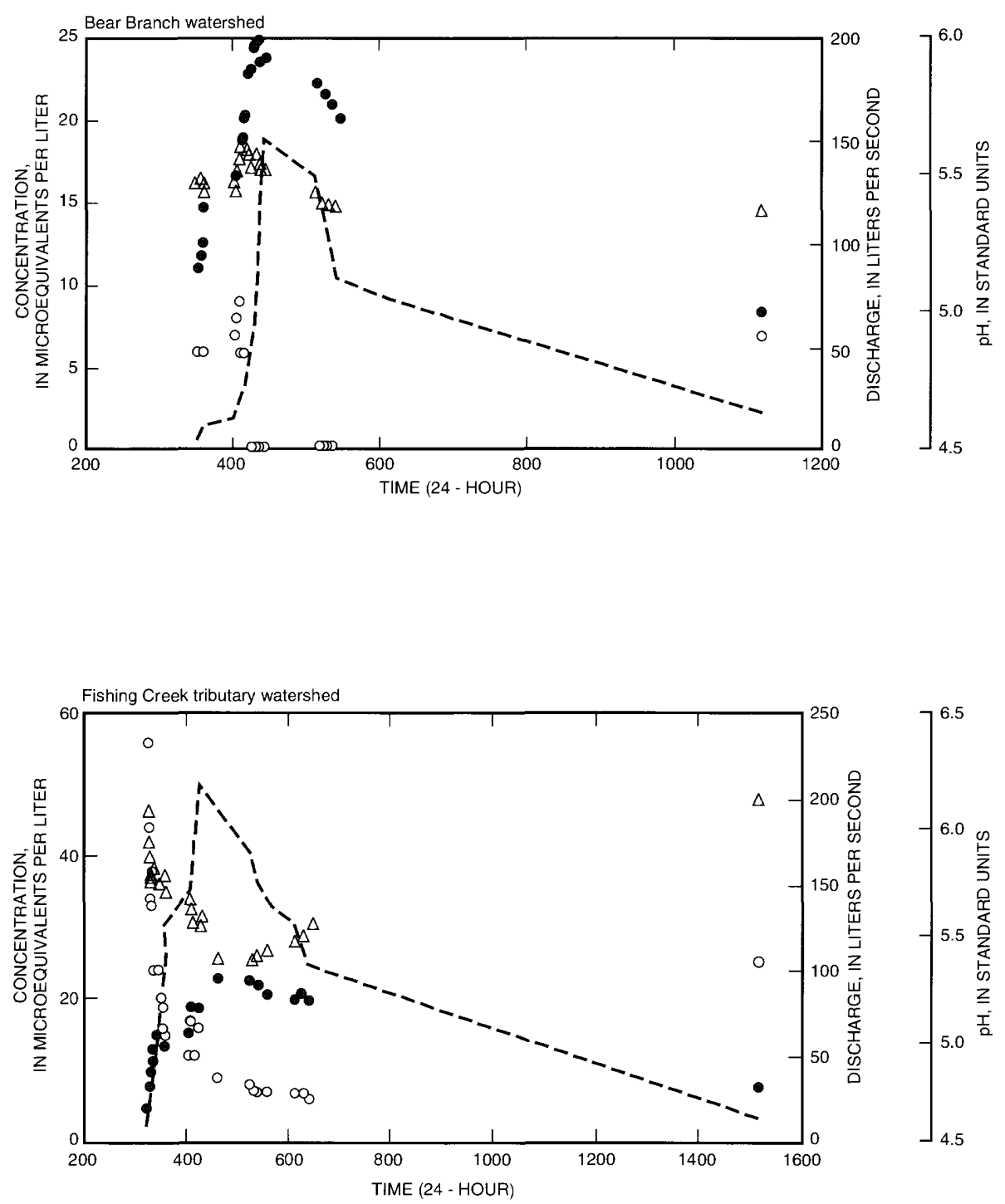

\section{EXPLANATION}

- - DISCHARGE, IN LITERS PER SECOND

$\triangle \quad$ PH, IN STANDARD UNITS

- ACID - NEUTRALIZING CAPACITY, IN MICROEQUIVALENTS PER LITER

- $\quad$ ALUMINUM CONCENTRATION, IN MICROEQUIVALENTS PER LITER

Figure 14. Episodic acidification in streamwater and Bear Branch and Fishing Creek tributary watersheds, Catoctin Mountain, Maryland, June 18, 1991. 
Bedrock containing carbonate minerals (for example, limestone and dolomite) or ultramafic minerals (for example, serpentine, dunite, and gabbro) is quite reactive because the kinetics of dissolution of these minerals is rapid. Ground water and streamwater associated with these types of bedrock generally are neutral or alkaline, and watersheds on these rock types will not become acidified by acidic deposition.

Other bedrock types are silicic (for example, quartzite and granite), which contain few reactive minerals. Ground water and streamwater associated with silicic rock types generally have low alkalinity and a $\mathrm{pH}$ near 6.0 under natural weathering conditions. When this type of watershed is stressed by acidic deposition, the waters commonly become more acidic because few reactive minerals are present to neutralize the acidity and because the reactive minerals present exhibit slow dissolution kinetics. When the only reactive minerals present in a watershed have slow dissolution kinetics, a long contact time between water and mineral is required for a significant amount of reaction to take place. The effect of water flow paths is particularly important in watersheds developed on these rock types because they determine the residence time of water and, therefore, the degree of reaction between the water and the kinetically slow-reacting minerals.

In Eastern United States, stream base flow varies seasonally, with higher flows in the winter and early spring and lower flows in the summer and early fall. Superimposed on the base flow is the short duration high flow associated with storms and with snowmelt in regions where a snowpack develops during the winter. Summer and fall base flow is usually derived entirely from the aquifer during the period that the top of the water table is located within the bedrock beneath the regolith-bedrock contact. This water has undergone extensive reaction with primary bedrock minerals and reflects these reactions in the ANC and base-cation concentrations. During winter and spring, the water table is usually nearer the land surface and may be above the regolith-bedrock contact. Under these conditions, the water contacts fewer of the primary bedrock minerals, and because of the higher water table, discharge to streams is generally greater and the residence time of water is shorter. Winter/ spring base flow is, therefore, less concentrated with respect to most constituents than summer/fall base flow.

Stormflow and snowmelt have minimal residence time in the watershed, and because of the shallow flow paths, there is also minimal contact with reactive minerals. This stormflow, therefore, is commonly acidic and causes episodic acidification of streams. The largest changes in $\mathrm{pH}$ and ANC during such episodes occur in streams draining watersheds developed on reactive bedrock because these streams have both high $\mathrm{pH}$ and ANC under normal flow conditions. However, even though the $\mathrm{pH}$ and ANC values change, seldom do streams of this type show a depression of $\mathrm{pH}$ or a reduction of the ANC sufficient to threaten aquatic organisms. A depression of $\mathrm{pH}$ or a reduction of the ANC in streams draining watersheds developed on some bedrock types, however, can be severe enough to affect the health of aquatic organisms. Watersheds most vulnerable to acidification by acidic deposition are those underlain by rock types that contain few reactive minerals and in which water moves through shallow flow paths, providing a short residence time for water-rock interaction.

Several watersheds in the Appalachian Highlands that are situated on bedrock types susceptible to acidic deposition have shown decreasing ANC for 1980-93. Mill Run watershed on Massanutten Mountain in north-central Virginia has been investigated by the USGS since 1982 (unpublished data at the U.S. Geological Survey in Reston, Va.). During 1982-88, seasonal cycles in ANC, base cations, and $\mathrm{SO}_{4}{ }^{2-}$ were indicated in Mill Run. In winter and spring, ANC and base-cation concentrations were low, and the concentration of $\mathrm{SO}_{4}{ }^{2-}$ was high. During summer and fall, ANC was positive, base-cation concentrations increased, and $\mathrm{SO}_{4}{ }^{2-}$ concentration decreased in Mill Run. In 1988, the ANC was negative, and the concentrations of base cations and $\mathrm{SO}_{4}{ }^{2-}$ remained essentially constant throughout the year. These conditions have persisted since 1988, except for the slightly positive ANC in 1991, a dry year with little rainfall and low stream discharge (unpublished data at the U.S. Geological Survey in Reston, Va.). 
During 1980-88, two watersheds on rock types susceptible to acidic deposition in the Shenandoah National Park in north-central Virginia were investigated by researchers at the University of Virginia (Ryan and others, 1989). These watersheds showed a consistent decrease in the ANC and an increase in $\mathrm{SO}_{4}{ }^{2-}$ during that period. All of these watersheds are retaining $\mathrm{SO}_{4}{ }^{2-}$; that is, more $\mathrm{SO}_{4}{ }^{2-}$ is entering in atmospheric deposition than is leaving in stream discharge. No trends in the concentration of $\mathrm{SO}_{4}{ }^{2-}$ in atmospheric deposition contributing to any of these watersheds have been observed during this period. The increases in $\mathrm{SO}_{4}{ }^{2-}$ concentration must result from internal watershed processes. No sources of $S$ are known in the watersheds (for example, sulfide mineralization or gypsum). Increases in $\mathrm{SO}_{4}{ }^{2-}$ concentrations in streamwater likely result from a decrease in the ability of the watershed soils to retain $\mathrm{SO}_{4}{ }^{2-}$ as an increasing number of sorption sites become saturated because of the substantial loadings of $\mathrm{SO}_{4}{ }^{2-}$ resulting from atmospheric deposition. If all of the sorption sites become saturated, the flux of $\mathrm{SO}_{4}^{2-}$ leaving the watershed in stream discharge will equal the flux of $\mathrm{SO}_{4}{ }^{2-}$ entering the watershed by way of atmospheric pathways, and no net retention of $\mathrm{SO}_{4}{ }^{2-}$ will result.

Streams in the Catoctin Mountain area of northcentral Maryland have been receiving acidic deposition (annual volume-weighted field measured $\mathrm{pH}=4.2$ ) since at least 1982, when the USGS began sampling in the area. It is not known when acidic deposition began to affect the Catoctin Mountain area; however, on the basis of investigations in the northeastern United States, deposition was probably quite acidic for at least two decades prior to 1982 (Likens and others, 1977).

Streams in the Catoctin Mountain area respond differently to acidic deposition depending upon the type of bedrock underlying the watershed. Streams draining watersheds underlain by greenstone, a moderately reactive rock type, maintain circumneutral $\mathrm{pH}$ in base flow year round, whereas streams draining watersheds on phyllite and quartzite (lessreactive rock types) usually have slightly acidic base flow (Bricker and Rice, 1989). In contrast, the well-buffered streams on the greenstone have the largest decreases in $\mathrm{pH}$ and in the ANC during storm runoff, although $\mathrm{pH}$ has not decreased below 6.0 nor has there been a complete loss of the ANC during the period of observation. Although the magnitude of $\mathrm{pH}$ depressions during storms is less in streams on phyllite and quartzite where base flow is slightly acidic than in streams on greenstone, the ANC commonly is reduced to near or below zero in streams on phyllite and quartzite (O'Brien and others, 1993).

\section{Bear Branch and Fishing Creek Tributary Watersheds}

The two watersheds investigated in this study are situated on one of the bedrock types most sensitive to acidic deposition. Interpretation of the hydrologic factors affecting the watersheds, the sources of stormflow, the geochemical factors affecting the watersheds, and the effects of these factors on the chemistry of the streamwater are discussed in the following sections.

\section{Hydrologic Factors}

Flow paths are difficult to identify because they are so numerous and spatially variable. However, some generalizations about the relative depths of flow paths can be made. Hydrologic and geochemical data indicate that base flow of the streams is provided by deeper ground-water flow paths than paths supplying stormflow in the two watersheds. Altitudes of near-stream ground-water levels are higher than altitudes of the stream levels for most of the year, indicating that ground water discharges to the streams and constitutes base flow. The hydrologic data are supported by the geochemical and isotopic data, which indicate that near-stream ground water is very similar in both geochemical and isotopic compositions to streamwater during base flow.

Flow paths that provide water to the streams during stormflow differ from the flow paths that provide streamwater during base flow. Measurements of altitudes of the near-stream water table during storms indicate that the water table rises rapidly relative to its pre-storm position (when it provided base flow to the stream). This change in altitude of the water table provides the opportunity 
for ground water to come into contact with parts of the soil horizon that had not been previously saturated, which can cause a change in chemical composition of the shallow ground water. This change in altitude of the water table also increases the hydraulic gradient of the near-stream ground water. At the same time, water that is entering the watersheds by way of throughfall infiltrates the ground surface and percolates through the soil horizon. During storms, downward-flowing water in the unsaturated zone intersects the water table and becomes incorporated into the ground-water system as shallow ground water. These changes in the physical locations of flow paths and increased hydraulic gradients cause stream discharge to increase during storms and cause the chemistry of stormflow to change relative to the chemistry of base flow.

\section{Sources of Stormflow}

Stormflow is commonly thought to be a combination of water that enters the basin during a storm ("event" water) and water that was present in the basin prior to the storm ("pre-event" water). Event water includes precipitation and throughfall. Preevent water consists of ground water, soil water, and water in surface storage. The specific types of event and pre-event waters are called "components" of storm runoff. The fractions of the two types of water contributing to stormflow, event and preevent, can be calculated by a storm hydrographseparation technique whereby a series of flow and mass-balance equations are solved simultaneously. These equations are of the form

$$
\begin{aligned}
Q_{t} & =Q_{p}+Q_{e}, \text { and } \\
C_{t} Q_{t} & =C_{p} Q_{p}+C_{e} Q_{e},
\end{aligned}
$$

where $Q$ is the discharge (volume/time), $C$ is the composition of the tracer (mass/volume), and the subscripts $t, p$, and $e$ refer to the total stream discharge, pre-event component, and event component, respectively. $Q_{t}$ is known because it is measured at the streamflow-gaging station; all of the $C$ terms are known because samples of the components are collected from the watershed and are analyzed in the laboratory. The fractions of $Q_{p}$ and $Q_{e}$ are the unknowns and can be determined if a number of assumptions are satisfied, as discussed below.

Sklash and Farvolden (1979) originally used a two-component, one-tracer model to evaluate the components of stormflow. Since then, the storm hydrograph-separation technique has evolved into three-component models because it was found that soil water can be an important component of stormflow (for example, Kennedy and others, 1986; DeWalle and others, 1988). These more complex models are still solved on the basis of flow and mass-balance equations, but there are more terms in the equations. For this study, a three-component, two-tracer spreadsheet model, called Separé (Sklash and others, in press), was used to perform the hydrograph separations. Two of the three components are considered pre-event water, and the third component is considered event water. The two pre-event waters are ground water and soil water, and the event-water component is throughfall. The assumptions inherent to performing stormhydrograph separations using this model are that: (1) the compositions of the pre-event components (ground water and soil water) must be significantly different from each other and from that of the event component (throughfall); (2) the compositions of all components are "conservative" (that is, the composition does not change as the water travels through the watershed to become stormflow), but mixing of event and pre-event waters can occur anywhere in the watershed; and (3) water in surface storage is not a significant contributor to stormflow.

The stable-isotope values of the various waters collected in the watersheds are useful in determining the water sources contributing to stormflow. The range of $\delta \mathrm{D}$ and $\delta^{18} \mathrm{O}$ becomes successively smaller as precipitation passes through various compartments of the watershed (fig.15). By the time the water reaches the water table, the isotopic composition is relatively uniform (fig. 15), which causes the isotope values in base flow to remain relatively stable throughout the year (fig. 16). Because the ground-water isotopic composition in these watersheds is uniform and different than that of soil water, when the isotopic composition of precipitation during an individual storm is significantly different from that of both pre-event waters, the hy- 

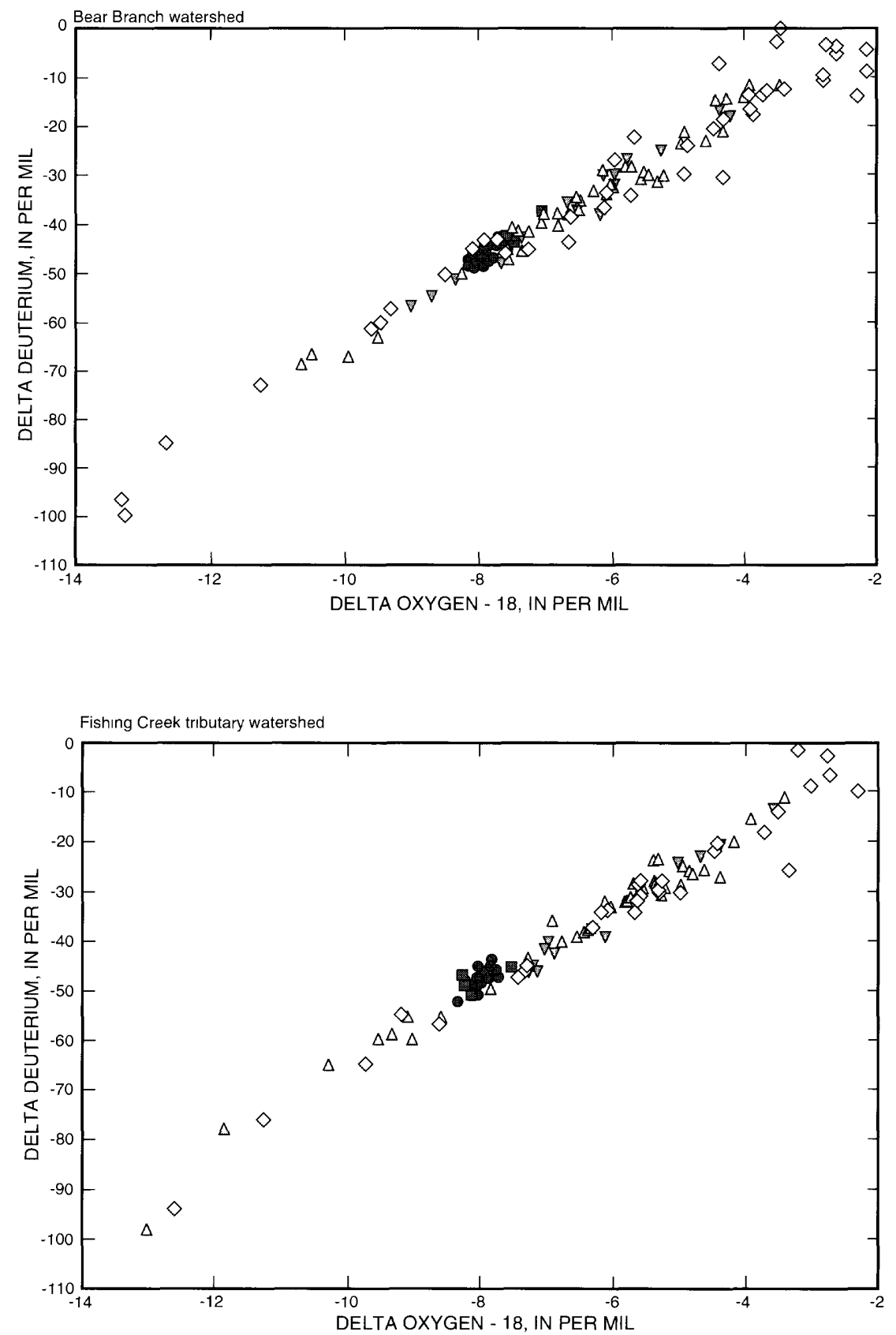

Figure 15. Isotopic variation of different types of water in Bear Branch and Fishing Creek tributary watersheds, Catoctin Mountain, Maryland, 1991-93. 

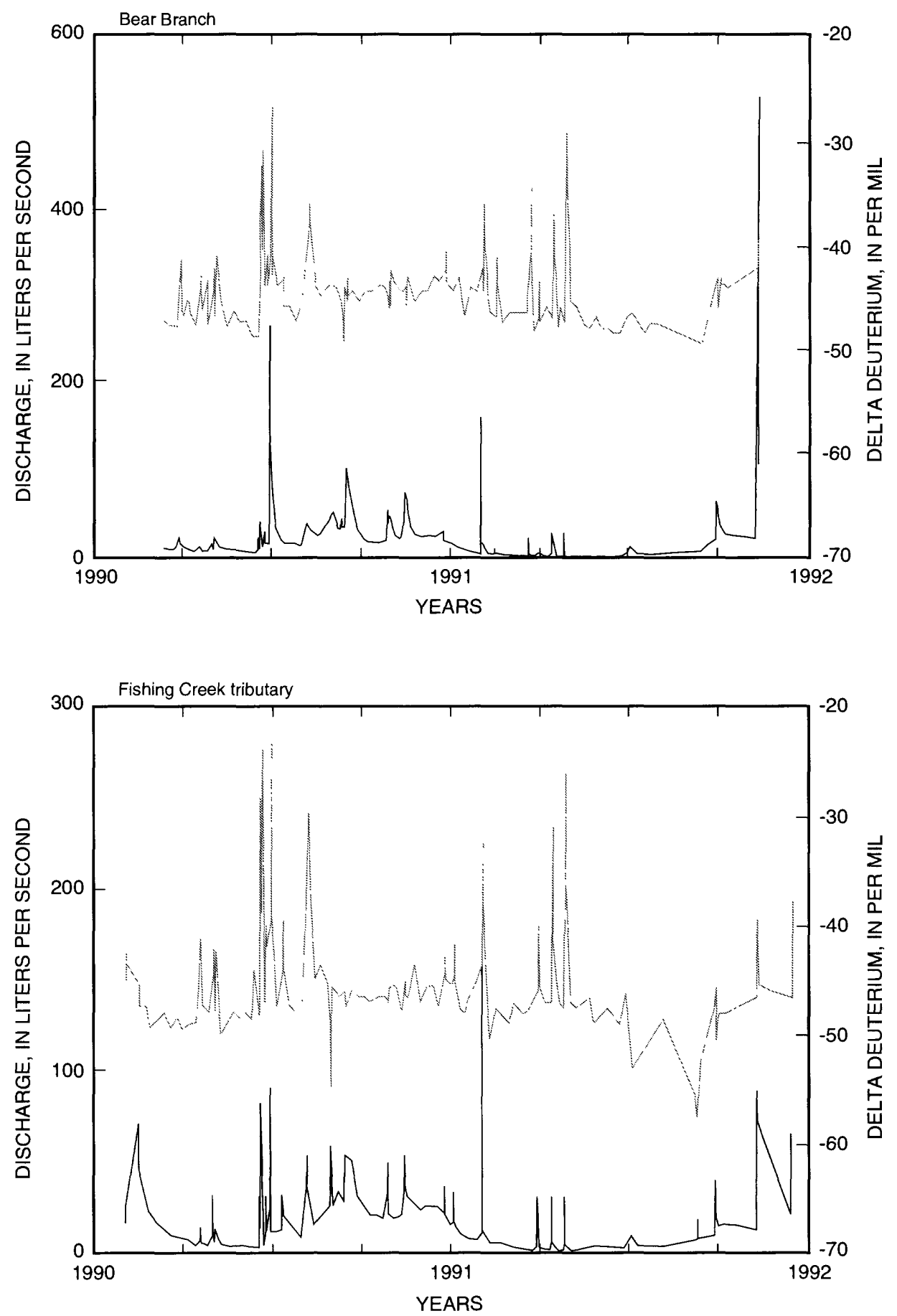

EXPLANATION

DELTA DEUTERIUM, IN PER MIL

DISCHARGE, IN LITERS PER SECOND

Figure 16. Stream discharge and isotopic variation in streamwater in Bear Branch, June 1990 through April 1992, and Fishing Creek tributary, May 1990 through May 1992, Catoctin Mountain, Maryland. 
drograph-separation model can be successfully applied. The tracers for the components of stormflow used in the model are $\delta \mathrm{D}$ and $\mathrm{Cl}^{-} . \delta \mathrm{D}$ is considered to be a conservative tracer because it is actually part of the water molecule and moves through the watershed in the molecule. Chloride also is generally considered to be a conservative tracer because it is not biologically reactive; there are usually no internal sources of it in the watershed, and it tends to be nonreactive with other ions in the water. The third assumption for successful hydrograph separation-that storage of water in surface depressions is an insignificant component of stormflow--is considered to be a valid assumption for these watersheds.

Stormflow-hydrograph separations were performed for the storms collected in each watershed throughout the period of study for which the assumptions of hydrograph separation could be satisfied. The tracer values of the throughfall component of storm runoff for each storm were obtained from the weekly sample of deciduous throughfall that included the storm. The tracer values of the soil-water component of storm runoff for each storm were obtained from the means of the data collected from the upper and lower pans of both lysimeter pits after the storm. If no lower pan soil-water data were available for a particular storm, the means of only the upper pans were used. In order to determine the tracer values of the ground-water component of storm runoff, all weekly and biweekly streamwater samples were categorized as either base flow or storm runoff on the basis of a visual determination from the annual hydrograph (fig. 13). The chemistry of the categorized base-flow samples was compared to that of shallow ground-water samples collected during base flow to ensure that the categorized samples were actual base-flow samples. Of the base-flow samples in Bear Branch, the mean value of $\delta \mathrm{D}$ was $-46.5 \% \circ(\mathrm{n}=66)$ and the mean value of $\mathrm{Cl}^{-}$was 37.6 $\mu \mathrm{eq} / \mathrm{L}(\mathrm{n}=85$ ); for Fishing Creek tributary, the mean value of $\delta D$ was $-47.7 \%$ o $(n=58)$, and the mean value of $\mathrm{Cl}^{-}$was $37.9 \mu \mathrm{eq} / \mathrm{L}(\mathrm{n}=191)$. Unlike precipitation, the isotopic signature of base flow shows no seasonal variation. Results of the stormflow-hydrograph separations at the peak of the hydrograph of each storm based on $\delta \mathrm{D}$ and $\mathrm{Cl}^{-}$are given in table 13.
Results of the stormflow-hydrograph separations are variable. A single component was considered to dominate stormflow if the hydrograph separation indicated that it was equal to or greater than 50 percent, provided that neither of the two other components was equal to 50 percent. These criteria were used to quantify the percentage of storms where a specific component dominated the flow at the peak of the hydrograph. For Bear Branch, the percentage of ground water contributing to the peak of the hydrograph ranged from 20 to 90 percent, soil water ranged from 0 to 80 percent, and throughfall ranged from 0 to 50 percent. For all of the 17 storms in the Bear Branch watershed during the period, ground water dominated stormflow at the peak of the hydrograph in 53 percent of the storms, soil water dominated in 24 percent of the storms, and throughfall dominated in 18 percent of the storms. For Fishing Creek tributary, the percentage of ground water contributing to the peak of the hydrograph ranged from 20 to 70 percent, soil water ranged from 0 to 80 percent, and throughfall ranged from 0 to 40 percent. For all of the 11 storms in the Fishing Creek tributary watershed during the period, ground water dominated stormflow at the peak of the hydrograph in 73 percent of the storms, soil water dominated in 27 percent of the storms, and throughfall dominated in none of the storms.

For some storms in both watersheds, results from the stormflow-separation model indicated that soil water contributed 0 percent of stormflow (table 13). This is very unlikely and indicates that the soil water that contributed to stormflow may not have been adequately characterized by the samples that were collected. Some storms had very high percentages ( 50 percent) of throughfall contributing to stormflow. This could occur if throughfall traveled through the soil zone along very shallow, short flow paths. The short transit time would prevent much mixing of the throughfall with soil waters and allow the throughfall to retain its isotopic signature.

The results of the stormflow-separation models suggest that Bear Branch is supplied, in general, by shallower flow paths than is Fishing Creek tributary, with flow paths that become even more shallow during stormflow. A comparison of the seven 
Table 13. Results of stormflow-hydrograph separations for selected storms, Bear Branch and Fishing Creek tributary watersheds, Catoctin Mountain, Maryland, October 1990 through December 1992

[Values given in percent]

\begin{tabular}{|c|c|c|c|}
\hline $\begin{array}{c}\text { Date of } \\
\text { storm } \\
\text { (month/day/yr) }\end{array}$ & Ground water & Soil water & Throughfall \\
\hline & \multicolumn{3}{|c|}{ Bear Branch } \\
\hline $10 / 11 / 90$ & 40 & 60 & 0 \\
\hline $10 / 13 / 90$ & 70 & 0 & 30 \\
\hline $10 / 18 / 90$ & 90 & 5 & 5 \\
\hline $10 / 23 / 90$ & 40 & 10 & 50 \\
\hline $11 / 05 / 90$ & 90 & 10 & 0 \\
\hline $03 / 04 / 91$ & 60 & 20 & 20 \\
\hline $05 / 06 / 91$ & 20 & 80 & 0 \\
\hline $06 / 18 / 91$ & 40 & 60 & 0 \\
\hline 08/19/91 & 70 & 0 & 30 \\
\hline $09 / 04 / 91$ & 50 & 40 & 10 \\
\hline $09 / 18 / 91$ & 40 & 10 & 50 \\
\hline $03 / 07 / 92$ & 90 & 10 & 0 \\
\hline $04 / 21 / 92$ & 60 & 30 & 10 \\
\hline $07 / 24 / 92$ & 40 & 10 & 50 \\
\hline $08 / 18 / 92$ & 50 & 0 & 50 \\
\hline $11 / 03 / 92$ & 20 & 50 & 30 \\
\hline \multirow[t]{2}{*}{$12 / 11 / 92$} & 50 & 40 & 10 \\
\hline & \multicolumn{3}{|c|}{ Fishing Creek tributary } \\
\hline 05/06/91 & 70 & 0 & 30 \\
\hline 05/17/91 & 60 & 40 & 0 \\
\hline $06 / 18 / 91$ & 20 & 80 & 0 \\
\hline 08/19/91 & 50 & 45 & 5 \\
\hline $09 / 05 / 91$ & 60 & 0 & 40 \\
\hline $09 / 18 / 91$ & 50 & 10 & 40 \\
\hline $02 / 15 / 92$ & 40 & 50 & 10 \\
\hline 03/07/92 & 50 & 50 & 0 \\
\hline $04 / 21 / 92$ & 40 & 55 & 5 \\
\hline $05 / 31 / 92$ & 50 & 10 & 40 \\
\hline $12 / 10 / 92$ & 50 & 10 & 40 \\
\hline
\end{tabular}


storms that were sampled simultaneously in the two watersheds also indicates that, in general, Bear Branch is supplied by shallower flow paths, with soil water or throughfall dominating the peak of the hydrograph more often than in the Fishing Creek tributary watershed. These results support the hypothesis that a watershed with higher hydraulic gradients (Bear Branch) tends to have shallower, shorter flowpaths than a watershed with lower hydraulic gradients (Fishing Creek tributary).

\section{Geochemical Factors}

The composition of streamwater in a watershed is affected by the chemistry of the input waters-precipitation and throughfall--and reactions that occur between these waters and watershed components. The precipitation input to these watersheds is usually very dilute, with $\mathrm{H}^{+}$ion the major cation and $\mathrm{SO}_{4}{ }^{2-}$ the major anion (table 9). The ammonium ion and the base cations constitute the remainder of the cation component, whereas $\mathrm{NO}_{3}{ }^{-}$, with smaller amounts of $\mathrm{Cl}^{-}$, constitute the remainder of the anion component. Throughfall is significantly more concentrated in most ions than is precipitation (fig. 5) because of wash off of material accumulated on leaves between storms and evaporation of precipitation intercepted by the tree canopy. 'Concentration differences between precipitation and throughfall are greatest during the summer when the trees are in full foliage, but even in winter when the deciduous trees are leafless, throughfall is more concentrated than precipitation.

Throughfall generally has slightly higher concentrations of cations than inorganic anions, indicating that dissolved organic anions are contributed by the canopy. Although concentrations of organic anions were not measured in the laboratory, the magnitude of the anion deficit gives an indication of the amount of organic anions present in the throughfall sample; that is, the larger the anion deficit, the greater the concentration of organic anions. The presence of organic anions in samples with anion deficits was confirmed in the laboratory by analysis of dissolved organic carbon (DOC) in the sample. When the throughfall reaches the forest floor and infiltrates, a sequence of materials is encountered with which it reacts. The water passes through the organic-litter layer, where the decom- position of abundant organic matter provides a source of DOC. Concentrations of elevated DOC relative to those in streamwater are present in the shallow soil waters of these watersheds. Concentrations of sulfate are elevated in soil water relative to streamwater because $\mathrm{SO}_{4}{ }^{2-}$ concentrations increase in throughfall as a result of wash off of dry deposition.

After passing through the organic-litter layer, the water encounters mineral soil. As the water moves downward through the soil profile, the DOC is oxidized to $\mathrm{CO}_{2}$ by microbes, which raises the partial pressure of $\mathrm{CO}_{2}$ of the soil waters relative to the open atmosphere. As $\mathrm{CO}_{2}$ dissolves in water, it releases $\mathrm{H}^{+}$ion to solution. This $\mathrm{H}^{+}$ion, in addition to the $\mathrm{H}^{+}$ion contributed by atmospheric deposition and throughfall, reacts with soil minerals and is partially neutralized by weathering reactions. The extent of $\mathrm{H}^{+}$-ion neutralization depends on the reactivity of the soil and bedrock minerals and the residence time of the waters in contact with the minerals. The $\mathrm{H}^{+}$ion dissolves aluminum hydroxides and aluminosilicate minerals present in the soil profile. The dissolution of these aluminum-rich minerals, which is greater at low $\mathrm{pH}^{\mathrm{s}} \mathrm{s}$ than at circumneutral $\mathrm{pH}$ 's, releases $\mathrm{Al}^{3+}$ to solution. The distribution of dissolved $\mathrm{Al}^{3+}$ in the waters in these watersheds indicates that $\mathrm{Al}^{3+}$ is derived from the soil zone but is not exceptionally mobile. The increase in $\mathrm{pH}$ of the waters as they travel through the watersheds probably inhibits the mobility of dissolved $\mathrm{Al}^{3+}$. The elevated $\mathrm{SO}_{4}{ }^{2-}$ concentrations present in the throughfall remain elevated in the soil waters. Sulfate concentration in shallow soil water increases relative to the throughfall concentration because acidic soils contain adsorbed $\mathrm{SO}_{4}{ }^{2-}$; as the water comes into contact with the soil, the $\mathrm{SO}_{4}{ }^{2-}$ can desorb and go into solution.

As the water travels deeper through the soil profile and finally encounters the water table, additional chemical changes result. The DOC, present in shallower waters, has been effectively oxidized by the time the waters reach depths of approximately 1 $\mathrm{m}$ below land surface. As a result, shallow ground water in these watersheds contains no detectable DOC. The abundant $\mathrm{H}^{+}$ion present in shallower waters is consumed in mineral weathering reactions in deeper ground water and decreases in concentra- 
tion. These mineral weathering reactions release base cations, $\mathrm{SiO}_{2}$, and $\mathrm{ANC}$ to solution, and the parent rock weathers to aluminum-silicate clays, such as kaolinite, in the soil zone. Elevated concentrations of base cations and $\mathrm{SiO}_{2}$ relative to their concentrations in input waters have been measured in samples of shallow ground water from the two watersheds. The shallow ground water in these watersheds is in contact with few reactive minerals, so neutralization of the $\mathrm{H}^{+}$ion in solution is not complete, and the ground water discharging to the streams is slightly acidic. The carbonic acid generated when $\mathrm{CO}_{2}$ dissolves in water is involved in reactions that produce ANC. Another source of ANC in perennially wet soils (riparian zones) along the stream channel is dissimulatory $\mathrm{SO}_{4}{ }^{2-}$ reduction: $\mathrm{SO}_{4}{ }^{2-}+2 \mathrm{C}_{\text {organic }}+2 \mathrm{H}_{2} \mathrm{O}=\mathrm{H}_{2} \mathrm{~S}+2 \mathrm{HCO}_{3}{ }^{-}$.

The reduction of $\mathrm{SO}_{4}{ }^{2-}$ causes $\mathrm{SO}_{4}{ }^{2-}$ concentrations to decrease and ANC to be generated. In the shallow well points in the Fishing Creek tributary watershed, the odor of hydrogen sulfide $\left(\mathrm{H}_{2} \mathrm{~S}\right)$ is apparent when the dark, fine-grained sediments in the bottom of the well points are disturbed. Additional evidence that $\mathrm{SO}_{4}{ }^{2-}$ reduction may be occurring in the Fishing Creek tributary watershed is the higher ANC and the lower concentration of $\mathrm{SO}_{4}{ }^{2-}$ in Fishing Creek tributary streamwater than in Bear Branch streamwater. The relative importance of $\mathrm{SO}_{4}{ }^{2-}$ reduction and $\mathrm{SO}_{4}{ }^{2-}$ adsorption in these systems has not been quantified; however, a significant amount of the incoming dissolved $\mathrm{SO}_{4}{ }^{2-}$ potentially could be lost to gas or solid phases through these processes. A gaseous phase could be produced through reduction of the $\mathrm{SO}_{4}{ }^{2-}$ to $\mathrm{H}_{2} \mathrm{~S}$, which would subsequently be evolved to the atmosphere. A solid phase could be produced through reduction of the $\mathrm{SO}_{4}{ }^{2-}$ and precipitation as iron sulfide.

Mass-balance calculations for the two watersheds indicate that $\mathrm{H}^{+}$ion deposited by precipitation is nearly all neutralized or exchanged, so that little $\mathrm{H}^{+}$ion is exported from the watershed on an annual basis. Analysis of the base cation and $\mathrm{SiO}_{2}$ wetdeposition loadings and the corresponding exports by the streams, and the neutralization of atmospheric inputs of $\mathrm{H}^{+}$ion indicates that weathering of silicate minerals occurs in the watersheds. ANC is generated as a product of silicate weathering. Larg- er amounts of ANC are exported in Fishing Creek tributary than in Bear Branch, suggesting that more weathering occurs in this watershed, or that dissimulatory $\mathrm{SO}_{4}{ }^{2-}$ reduction significantly contributes to ANC generation. Most importantly, from the standpoint of the effects of acidic deposition, is the processing of $\mathrm{SO}_{4}{ }^{2-}$ in the watersheds. Both watersheds export less $\mathrm{SO}_{4}{ }^{2-}$ than they receive through wet-deposition loadings, with Fishing Creek tributary exporting much less than Bear Branch on an annual basis. The apparent net retention of $\mathrm{SO}_{4}{ }^{2-}$ in both watersheds suggests that either $\mathrm{SO}_{4}{ }^{2-}$ adsorption or $\mathrm{SO}_{4}{ }^{2-}$ reduction or both may be important processes.

The chemistry of these systems can be modeled with the geochemical code NETPATH (Plummer and others, 1991). In the Bear Branch and Fishing Creek tributary watersheds during the growing season, the tree canopy is continuous over the watersheds and the streams, so there are very few open areas that receive direct precipitation. The chemistry of the input waters to these watersheds is, therefore, essentially that of throughfall. In model simulation, the average annual volume-weighted throughfall (or precipitation) composition is used as the initial water, and average annual volumeweighted streamwater composition is used as the final water. Information about the primary and secondary minerals present in the watershed, a botanical uptake term, and a dilution/evaporation factor are incorporated in the model.

Geochemical model simulation for Bear Branch for 1991, using the deciduous throughfall as the input water, shows that 0.085 millimoles (mmol) of aluminum hydroxide, $0.016 \mathrm{mmol}$ of chlorite, $0.027 \mathrm{mmol}$ of epidote, $0.024 \mathrm{mmol}$ of plagioclase feldspar, and $0.055 \mathrm{mmol}$ of potassium feldspar per kilogram of water dissolve and that $0.140 \mathrm{mmol}$ of kaolinite is formed per kilogram of water. These reactions account for the streamwater composition and the residual kaolinite in the watershed. The removal of $\mathrm{SO}_{4}{ }^{2-}$ in some form (reduction to $\mathrm{H}_{2} \mathrm{~S}$ or precipitation as $\mathrm{FeS}_{2}$ ) is allowed in model simulation, and $\mathrm{NO}_{3}{ }^{-}$and the base cations $\mathrm{Ca}^{2+}, \mathrm{Mg}^{2+}$, and $\mathrm{K}^{+}$are attributed to botanical uptake. 
Geochemical model simulation for Fishing Creek tributary for 1991, using the deciduous throughfall as the contributing water, shows that $0.014 \mathrm{mmol}$ of chlorite, $0.019 \mathrm{mmol}$ of epidote, $0.039 \mathrm{mmol}$ of plagioclase feldspar, and 0.182 mmol of potassium feldspar per kilogram of water dissolve and that $0.322 \mathrm{mmol}$ of kaolinite is formed per kilogram of water. Using throughfall as the input term necessitates the concentration, through evaporation, of the input water by a factor of 2.9 , allows the removal of $\mathrm{SO}_{4}{ }^{2-}$ in some form, allows the generation of $\mathrm{CO}_{2}$ gas, and attributes $\mathrm{NO}_{3}{ }^{-}$and the base cations $\mathrm{Ca}^{2+}, \mathrm{Mg}^{2+}$, and $\mathrm{K}^{+}$to botanical uptake. Reconstructions of the chemical compositions of the streamwater in both watersheds in 1991 from weathering of primary and secondary minerals are shown in figure 17.

During stormflow, $\mathrm{SO}_{4}{ }^{2-}$ concentrations increase as a result of the remobilization of $\mathrm{SO}_{4}{ }^{2-}$ temporarily stored in the unsaturated zone. Also during stormflow, concentrations of the base cations $\mathrm{Ca}^{2+}$, $\mathrm{Mg}^{2+}$, and $\mathrm{K}^{+}$increase. This increase in base cations during stormflow is unlike the behavior of base cations in watersheds on more reactive bedrock types on Catoctin Mountain, where decreases in concentrations of base cations result during stormflow due to dilution. Two hypotheses could explain this concentration of base cations during stormflow in the two watersheds studied. The first hypothesis is that throughfall and dry deposition supply the additional base cations to the watersheds. Between storms, the base cations accumulate and are stored in the unsaturated zone in pore solutions or as $\mathrm{Cl}^{-}$ and $\mathrm{SO}_{4}{ }^{2-}$ salts. During storms, the cations are quickly mobilized and routed to the streams along shallow flow paths before tree roots are able to uptake and incorporate them into the botanical cycle. The second hypothesis involves cation exchange. Hydrogen ions in the incoming precipitation and throughfall exchange for $\mathrm{Ca}^{2+}$ and $\mathrm{Mg}^{2+}$ ions on exchange sites on watershed components; the $\mathrm{Ca}^{2+}$ and $\mathrm{Mg}^{2+}$ ions then travel rapidly through the system to contribute to stormflow.

The first hypothesis is plausible because the streamwaters are so dilute that only small amounts of cations contributed to the watershed are needed to increase concentrations. In contrast, in watersheds with waters with higher concentrations of cat- ions, the relatively dilute throughfall has no effect on the concentrations of stormflow. An increase in $\mathrm{Cl}^{-}$concentration in stormflow was observed in some of the storms sampled, and an increase in $\mathrm{SO}_{4}{ }^{2-}$ concentration in stormflow was observed in all storms sampled (fig. 5). The second hypothesis applies to many watersheds in the northeastern United States; however, the fact that the cationexchange capacities of the soils in these watersheds are low (tables 3 and 4 ) suggests that the process of cation exchange might not be as important as contributions from throughfall in explaining the concentration of base cations during stormflow.

\section{Transferability and Limitations of Results}

The findings of the watershed investigations on Catoctin Mountain have substantial transferability not only to the rest of the Blue Ridge Physiographic Province in Maryland, but to watersheds underlain by rock types with similar mineralogy across the United States and in other countries. Results of sampling numerous streams flowing on quartzite, phyllite, and greenstone in the Maryland Blue Ridge Physiographic Province indicate that the chemistry of streamwater and the sensitivity of streams to acidification can be determined based on the geology of the watersheds (Bricker and Rice, 1989). Streams flowing on quartzite in the Virginia Blue Ridge Physiographic Province behave in an identical manner to those on Catoctin Mountain (Lynch and Dise, 1985; Ryan and others, 1989; Webb and others, 1994). Investigations of streams in watersheds underlain by quartzite and sandstone in other areas of Maryland and Virginia, in other regions of the United States, and in other countries show that the chemistry of the streams is consistent and predictable based on watershed geology (Corbett and Lynch, 1982; Lynch and Dise, 1985; Lynch and others, 1986; Bricker, 1986; Reynolds and others, 1986; Fottova, 1987; Dewalle and others, 1987; Barker and Witt, 1990; Murdoch, 1991; Finley and Drever, 1992). Streams flowing on unconsolidated siliciclastic formations of the Coastal Plain Physiographic Province of Maryland and Virginia have similar chemistries to those streams flowing on quartzite and sandstone (Knapp and others, 1988b; Kuebler, 1991; Rice and Bricker, 1992b; O'Brien and others, 1993). 

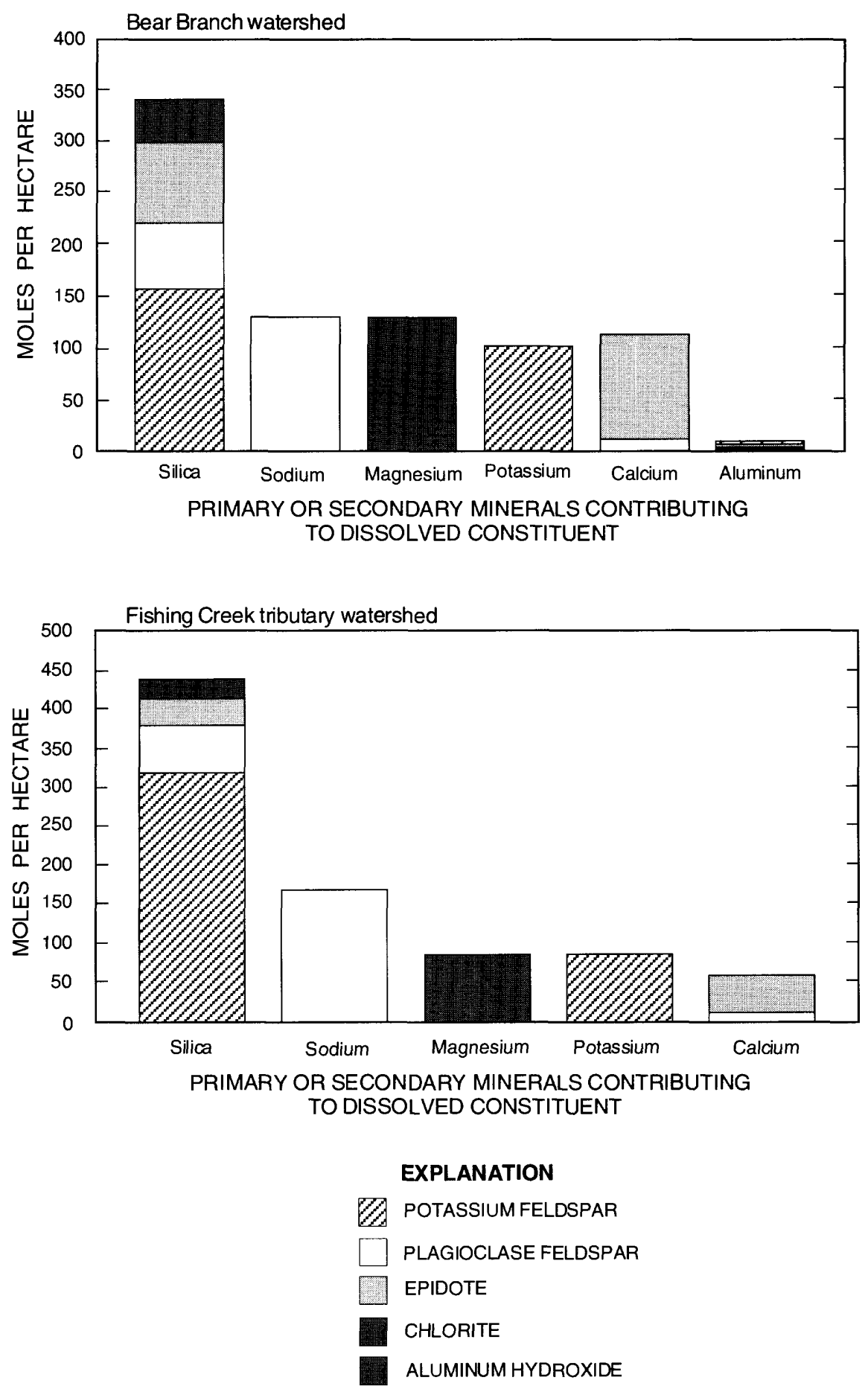

Figure 17. Reconstruction of chemical composition of streamwater in 1991 from weathering of primary and secondary minerals for Bear Branch and Fishing Creek tributary watersheds, Catoctin Mountain, Maryland. 
The largest differences among watersheds on similar rock types occur in the behavior of DOC and dissolved nitrogen species. Coastal Plain streams commonly contain much higher concentrations of DOC than do streams in the Piedmont, Blue Ridge, Folded Appalachian or Appalachian Plateau Physiographic Provinces. The DOC content of streams has implications about the behavior and toxicity of aluminum in waters. Streams with high DOC concentrations can have much higher concentrations of aluminum without being toxic to aquatic organisms than do streams with low concentrations of DOC (Driscoll and others, 1980). This is related to the complexation of aluminum by dissolved organic compounds, which forms an aluminum-organic complex that has much lower toxicity than inorganic-aluminum species. The behavior of nitrogen species in these streams is related to the type and stage of growth of vegetation in the watershed, the season of the year, and the nitrogen loading to the watershed from atmospheric deposition.

\section{SUMMARY}

The hydrology and geochemistry of Bear Branch and Fishing Creek tributary, two small headwater streams on Catoctin Mountain, northcentral Maryland, were investigated from 1990 through 1993. The streams were chosen because they drain undisturbed forested watersheds that (1) are developed on a rock type that has very little capacity to buffer acidity, and (2) receive some of the most acidic atmospheric deposition in Maryland. Effects of acidic deposition would be expected to occur first in undisturbed forested watersheds with low buffering capacities and would serve as an indicator for potential future changes in watersheds with higher buffering capacities. Investigations show that under base-flow conditions, watershed processes maintain the stream $\mathrm{pH}$ in a slightly acidic range (pH 5.0-6.0) and generate a small, but positive, acid-neutralizing capacity (ANC). Base flow of the streams is primarily maintained by groundwater discharge, water that has traversed deeper flow paths and has had longer contact with watershed materials than waters from the shallow soil zone. Isotopic investigations indicate that most recharge to ground water occurs during November through April when forest vegetation is dormant.
The relative stability of the isotopic composition of base flow during a 3-year period of measurement suggests that the water in the aquifer is well mixed. Simulating changes in chemistry between atmospheric deposition inputs and stream base flow with the geochemical code NETPATH indicates the potential importance of mineral weathering in affecting water chemistry in these watersheds.

In contrast to base-flow conditions, during stormflow, water is contributed to the stream from sources in addition to the aquifer. Stormflow hydrograph-separation techniques suggest that stormflow comprises water from at least three sources: the aquifer (pre-event water), water stored in the unsaturated zone (pre-event water), and water from the storm (event water). The major contributors to stormflow are the aquifer and water from the unsaturated zone (pre-event water). Smaller portions of water from the storm (event water) contribute to stormflow. During storms, the buffer capacity of watersheds sensitive to acidification is overwhelmed, pH is depressed, and the ANC decreases or, in some storms, becomes negative. Episodic acidification may significantly affect the biological resources of these watersheds.

The two watersheds studied are typical of watersheds throughout the Blue Ridge Province underlain by siliciclastic rocks and of other watersheds, worldwide, underlain by similar rock types. These watersheds represent one of the most sensitive types of hydrologic systems to the effects of acidic deposition and could serve as early-warning indicators for changes resulting from the effects of acidic deposition. 


\section{REFERENCES CITED}

Acker, J.G., and Bricker, O.P., 1992, The 'simplest' watershed--An in-situ study of bedrockatmospheric deposition reactions: Proceedings Volume of the 7th International Symposium on Water-Rock Interaction, Park City, Utah, July 13-19, 1992, p. 533-536.

Baker, J.P., Bernard, D.P., Christensen, S.W., Sale, M.J., Freda, Joseph, Heltcher, K.J., Marmorek, D.R., Rowe, Locke, Scanlon, P.F., Suter, G.W., Warren-Hicks, W.J., and Welborne, P.M., 1990, Biological effects of changes in surface water acid-base chemistry, in volume II, Acidic deposition--State of science and technology: National Acid Precipitation Assessment Program, Report 13, 381 p.

Barker, J.L., and Witt, E.C., 1990, Effects of acidic precipitation on the water quality of streams in the Laurel Hill area, Somerset County, Pennsylvania, 1983-86: U.S. Geological Survey Water-Resources Investigations Report 89-4113, 72 p.

Bricker, O.P., 1986, Geochemical investigations of selected Eastern United States watersheds affected by acid deposition: Journal of the Geological Society of London, v. 143, p. 621-626.

Bricker, O.P., and Rice, K.C., 1989, Acidic deposition to streams--A geology-based method predicts their sensitivity: Environmental Science \& Technology, v. 23, no. 4 , p. 379-385.

Buchanan, T.J., and Somers, W.P., 1968, Stage measurements at gaging stations: U.S. Geological Survey Techniques of Water-Resources Investigations, book 3, chap. A7, 28 p.

1969, Discharge measurements at gaging stations: U.S. Geological Survey Techniques of Water-Resources Investigations, book 3, chap. A8, 65 p.

Coplen, T.B., 1993, Uses of environmental isotopes, $\underline{\text { in }}$ Alley, W.M., ed., Regional ground-water quality: New York, Van Nostrand Reinhold, p. 227-253.

Coplen, T.B., Wildman, J.D., and Chen, Julie, 1991, Improvements in the gaseous hydrogen-water equilibration technique for hydrogen isotope ratio analysis: Analytical Chemistry, v. 63, p. 910-912.

Corbett, E.S., and Lynch, J.A., 1982, Rapid fluctuations in streamflow $\mathrm{pH}$ and associated water-quality pa- rameters during a stormflow event, in International Symposium on Hydrometeorology: Bethesda, Maryland, American Water Resources Association, p. 461-464.

Craig, Harmon, 1961, Isotopic variations in meteoric waters: Science, v. 133, p. 1702-1703.

Dansgaard, W., 1964, Stable isotopes in precipitation: Tellus, v. 16 , no. 4 , p. $436-468$.

DeWalle, D.R., Dinicola, R.S., and Sharpe, W.E., 1987, Predicting baseflow alkalinity as an index to episodic stream acidification and fish presence: Water Resources Bulletin, v. 23, p. 24-35.

DeWalle, D.R., Swistock, B.R., and Sharpe, W.E., 1988, Three-component tracer model for stormflow on a small Appalachian forested catchment: Journal of Hydrology, v. 104, p. 301-310.

Driscoll, C.T., Baker, J.P., Bisogni, J.J., Jr., and Schofield, C.L., 1980, Effects of aluminum speciation on fish in dilute acidified waters: Nature, v. 284, p. 161-164.

Epstein, Samuel, and Mayeda, T.K., 1953, Variation of $\mathrm{O}-18$ content of waters from natural sources:

Geochimica et Cosmochimica Acta, v. 4, p. 213-224.

Fauth, J.L., 1977, Geologic map of the Catoctin Furnace and Blue Ridge Summit quadrangles, Maryland: Maryland Geological Survey, 1 sheet, scale 1:24,000.

Fenneman, N.N., 1946, Physical divisions of the United States: Washington, D.C., U.S. Geological Survey, map scale 1:7,000,000.

Finley, J.B., and Drever, J.I., 1992, Chemical hydrograph separation using field and experimental data with implications for solute cycling in an alpine catchment: Proceedings Volume of the 7th International Symposium on Water-Rock Interaction, Park City, Utah, July 13-19, 1992, p. 553-556.

Fottova, Daniela, 1987, Acidification of surface waters in different geological environments of the Bohemian Massif, in Moldan, B. and Paces, T., eds., Proceedings of GEOMON International Workshop on Geochemistry and Monitoring in Representative Basins: Prague, Czechoslovakia, p. 89-91.

Janicki, Anthony, and Cummins, R., 1983, An analysis of survey data on the chemistry of twenty-three 
streams in the Chesapeake Bay watershed--Some implications of the impact of acid deposition: Annapolis, Maryland Department of Natural Resources, Power Plant Siting Program, Report PPSP-AD-7 [variously paged].

Janicki, Anthony, and Greening, Holly, 1987, A summary of Maryland stream $\mathrm{pH}$ and alkalinity data--An analysis of its application to assessing the impacts of acid deposition: Annapolis, Maryland Department of Natural Resources, Power Plant Siting Program, Report AD-87-11 [variously paged].

Katz, B.G., 1989, Influence of mineral weathering reactions on the chemical composition of soil water, springs, and ground water, Catoctin Mountains, Maryland: Hydrological Processes, v. 3, p. 185-202.

Katz, B.G., Bricker, O.P, and Kennedy, M.M., 1985, Geochemical mass-balance relationships for selected ions in precipitation and stream water, Catoctin Mountains, Maryland: American Journal of Science, v. 285 , p. $931-962$.

Kazmann, R.G., 1965, Modern hydrology: New York, Harper \& Row Publ., 301 p.

Kendall, Carol, Mast, M.A., and Rice, K.C., 1992, Tracing watershed weathering reactions with $\delta^{13} \mathrm{C}$ : Proceedings Volume of the 7th International Symposium on Water-Rock Interaction, Park City, Utah, July 13-19, 1992, p. 569-572.

Kennedy, E.J., 1983, Computation of continuous records of streamflow: U.S. Geological Survey Techniques of Water-Resources Investigations, book 3, chap. A13, 53 p.

1984, Discharge ratings at gaging stations: U.S. Geological Survey Techniques of Water-Resources Investigations, book 3, chap. A10, 59 p.

Kennedy, V.C., Kendall, Carol, Zellweger, G.W., Wyerman, T.A., and Avanzino, R.J., 1986, Determination of the components of stormflow using water chemistry and environmental isotopes, Mattole River Basin, California: Journal of Hydrology, v. 84, p. 107-140.

Knapp, C.M., Filbin, G.J, and Bonoff, M.D., 1988a, Maryland long-term stream chemistry monitoring program: Annapolis, Maryland Department of Natural Resources, Report AD-88-3 [variously paged].
Knapp, C.M., Sanders, W.P., Heimbuch, D.G., Filben, G.J., and Greening, Holly, 1988b, Maryland synoptic stream chemistry survey--Estimating the number and distribution of streams affected by or at risk from acidification: Annapolis, Maryland Department of Natural Resources, Power Plant Research Program, Report AD-88-3, 214 p.

Kuebler, Anne, 1991, Chemical variability in a wetlandinfluenced Coastal Plain stream: Charlottesville, University of Virginia, master's thesis, $138 \mathrm{p}$.

Likens, G.E., Bormann, F.H., Pierce, R.S., Eaton, J.S., and Johnson, N.M., 1977, Biogeochemistry of a forested ecosystem: New York, Springer-Verlag, 146 p.

Lovett, G.M., and Lindberg, S.E., 1984, Dry deposition and canopy exchange in a mixed oak forest as determined by analysis of throughfall: Journal of Applied Ecology, v. 21, p. 1013-1027.

Lynch, D.D., and Dise, N.D., 1985, Sensitivity of stream basins in Shenandoah National Park to acid deposition: U.S. Geological Survey Water-Resources Investigations Report 85-4115, 61 p.

Lynch, J.A., Hanna, C.M., and Corbett, E.S., 1986, Predicting $\mathrm{pH}$, alkalinity and total acidity in streamwater during episodic events: Water Resources Research, v. 22, p. $905-912$.

Matthews, E.D., 1960, Soil survey of Frederick County, Maryland: Washington, D.C., U.S. Department of Agriculture, Soil Conservation Service, Series 1956, no. $15,144 \mathrm{p}$.

Meybeck, Michele, 1984, Variabilite geographique de la composition chimique naturelle des eaux courantes: Verhandlungen-Internationale Vereinigung fur Theoretische und Angewandte Limnologie, v. 22, no. 3, p. 1766-1774.

Murdoch, P.S., 1991, Chemical budgets and stream chemistry dynamics of a headwater stream in the Catskill Mountains, New York, 1984-85: U.S. Geological Survey Water-Resources Investigations Report, 88-4038, $66 \mathrm{p}$.

National Oceanic and Atmospheric Administration, 1981, Division normals and standard deviations of temperature and precipitation (1931-80): U.S. Department of Commerce, Climatography of the United States, no. $85,176 \mathrm{p}$. 
O'Brien, A.K., Rice, K.C., Bricker, O.P., Kennedy, M.M., and Anderson, R.T., in press, Geochemical mass balance modeling--A tool for evaluating the role of weathering in determining stream chemistry in five Mid-Atlantic watersheds on different bedrock: $\mathrm{Hy}$ drological Processes.

O'Brien, A.K., Rice, K.C., Kennedy, M.M., and Bricker, O.P., 1993, Comparison of episodic acidification of Mid-Atlantic upland and Coastal Plain streams: Water Resources Research, v. 29, no. 9, p. 3029-3039.

Peters, N.E., 1994, Water-quality variations in a forested Piedmont catchment, Georgia, USA: Journal of Hydrology, v. 156, p. 73-90.

Pilgrim, D.H., Huff, D.D., and Steele, T.D., 1979, Use of specific conductance and contact time relations for separating flow components in storm runoff: Water Resources Research, v. 15, p. 329-339.

Plummer, L.N., Prestemon, E.C., and Parkhurst, D.L., 1991, An interactive code (NETPATH) for modeling Net geochemical reactions along a flow Path: U.S. Geological Survey Water-Resources Investigations Report 91-4078, 227 p.

Puckett, L.J., 1987, The influence of forest canopies on the chemical quality of water and the hydrologic cycle, in Averett, R.C., and McKnight, D.M., eds., Chemical quality of water and the hydrologic cycle: Chelsea, Michigan, Lewis Publ., Inc., 382 p.

1991, Spatial variability and collector requirements for sampling throughfall volume and chemistry under a mixed-hardwood canopy: Canadian Journal of Forest Research, v. 21, p. 1581-1588.

Reynolds, B., Neal, Colin, Hornung, M., and Stevens, P.A., 1986, Baseflow buffering of streamwater acidity in five mid-Wales catchments: Journal of Hydrology, v. 87, p. 167-185.

Rice, K.C., and Bricker, O.P., 1992a, Acid-rain induced changes in streamwater quality during storms on $\mathrm{Ca}-$ toctin Mountain, Maryland: U.S. Geological Survey Open-File Report 92-649, Water Fact Sheet, 2 p.

1992b, Acid rain and its effect on streamwater quality on Catoctin Mountain, Maryland: U.S. Geological Survey Open-File Report 92-168, Water Fact Sheet, $2 \mathrm{p}$.
1993, Hydrologic, chemical, and isotopic characterization of two small watersheds on Catoctin Mountain, north-central Maryland, U.S.A.: Chemical Geology, v. 107, p. 319-321.

1995a, Seasonal cycles of dissolved constituents in streamwater in two forested catchments in the midAtlantic region of the Eastern U.S.: Journal of Hydrology, v. 170, p. 137-158.

1995b, Seasonal cycles in streamwater quality on Catoctin Mountain, Maryland: U.S. Geological Survey Fact Sheet FS-136-95, 2 p.

Rice, K.C., Kennedy, M.M., Bricker, O.P., and Donnelly, C.A., 1993, Data on the quantity and chemical quality of precipitation, Catoctin Mountain, northcentral Maryland, 1982-91: U.S. Geological Survey Open-File Report 93-169, 46 p.

Rice, K.C., Kennedy, M.M., Carter, C.A., Anderson, R.T., and Bricker, O.P., in press [1996], Hydrologic and water-quality data for two small watersheds on Catoctin Mountain, north-central Maryland, 1987-93: U.S. Geological Survey Open-File Report 95-151, $195 \mathrm{p}$.

Robertson, J.K., and Wilson, J.W., 1985, Design of the National Trends Network for monitoring the chemistry of atmospheric precipitation--U.S. Geological Survey, National Acid Precipitation Assessment Program: U.S. Geological Survey Circular 964, 46 p.

Ryan, P.F., Hornberger, G.M., Cosby, B.J., Galloway, J.N., Webb, J.R., and Rastetter, E.B., 1989, Changes in the chemical composition of stream water in two catchments in the Shenandoah National Park, Virginia, in response to atmospheric deposition of sulfur: Water Resources Research, v. 25, p. 2091-2099.

Sklash, M.G., Beven, K.J., Darling, W.G., and Gilman, $\mathrm{K}$., in press, Isotope studies of pipeflow at Plynlimon, Wales, U.K., Part 2. Storm flow: Hydrological Processes.

Sklash, M.G., and Farvolden, R.N., 1979, The role of groundwater in storm runoff: Journal of Hydrology, v. 43, p. $45-65$.

Stumm, Werner, and Morgan, J.J., 1981, Aquatic Chemistry--An introduction emphasizing chemical equilibria in natural waters: New York, Wiley-Interscience Publication, John Wiley \& Sons, New York, 780 p. 
Trainer, F.W., and Watkins, F.A., Jr., 1975, Geohydrologic reconnaissance of the upper Potomac River Basin: U.S. Geological Survey Water-Supply Paper 2035, 68 p.

Trombley, T.J., and Zynjuk, L.D., 1985, Hydrogeology and water quality of the Catoctin Mountain National Park area, Frederick County, Maryland: U.S. Geological Survey Water-Resources Investigations Report $85-4241,41 \mathrm{p}$.

Turk, J.T., and Campbell, D.H., 1984, Prediction of lake alkalinity in the Rocky Mountains, western United States, in Air quality and acid deposition potential in the Bridger and Fitzpatrick Wildernesses: Ogden, Utah, U.S. Forest Service, p. 268-274.

U.S. National Acid Precipitation Assessment Program, 1991, Acidic deposition, in Irving, P.M., ed., State of science and technology, Summary report: Washington D.C., 265 p.

Velbel, M.A., 1992, Geochemical mass balances and weathering rates in forested watersheds of the Southern Blue Ridge, III. Cation budgets and the weathering rate of amphibole: American Journal of Science, v. 292 , p. $58-78$.

Webb, J.R., Deviney, F.A., Galloway, J.N., Rinehart, C.A., Thompson, P.A., and Wilson, S., 1994, The acid-base status of native brook trout streams in the mountains of Virginia: Charlottesville, University of Virginia, Department of Environmental Sciences, $75 \mathrm{p}$.

Wigington, P.J., Davies, T.D., Tranter, Martyn, and Eshleman, K.N., 1990, Episodic acidification of surface waters due to acidic deposition, in volume II, Acidic deposition--State of science and technology: National Acid Precipitation Assessment Program Report 12, $200 \mathrm{p}$. 